UNIVERSIDADE DE SÃO PAULO

FACULDADE DE FILOSOFIA, LETRAS E CIÊNCIAS HUMANAS

DEPARTAMENTO DE LETRAS MODERNAS

PROGRAMA DE PÓS-GRADUAÇÃO EM ESTUDOS LINGUÍSTICOS E LITERÁRIOS EM INGLÊS

Renato Razzino Ernica

\title{
Uma perspectiva intercultural sobre o jogar
}

Versão Original

São Paulo 


\section{Uma perspectiva intercultural sobre o jogar}

Tese de Doutorado apresentada ao Programa de Pós-graduação em Estudos Linguísticos e Literários em Inglês da Faculdade de Filosofia, Letras e Ciências Humanas, da Universidade de São Paulo, como parte dos requisitos para obtenção do título de Doutor em Letras.

Orientadora: Prof. $^{a}$ Dr. $^{a}$ Elizabeth Harkot de La Taille 
Autorizo a reprodução e divulgação total ou parcial deste trabalho, por qualquer meio convencional ou eletrônico, para fins de estudo e pesquisa, desde que citada a fonte.

Catalogação na Publicação

Serviço de Biblioteca e Documentação

Faculdade de Filosofia, Letras e Ciências Humanas da Universidade de São Paulo

Ernica, Renato Razuino

EE71p Uma perspectiva intercultural sobre o jogar / Renato Razzino Ernica ; orientadora Elizabeth Harkotde-La-Taille. - São Paulo, 2019.

$151 \mathrm{f}$.

Tese (Doutorado) - Faculdade de Filosofia, Letras e Ciências Humanas da Universidade de São Paulo. Departamento de Letras Modernas. Área de concentração: Estudos Linguísticos e Literários em Inglês.

1. Semiótica. 2. Jogos. 3. Colonialismo. I. Harkotde-La-Taille, Elizabeth, orient. II. Título. 
ERNICA, R. R. Uma perspectiva intercultural sobre o jogar. Tese apresentada à Faculdade de Filosofia, Letras e Ciências Humanas da Universidade de São Paulo para obtenção do título de Doutor em Letras.

Aprovado em:

Banca Examinadora

Prof. Dr.

Julgamento:

Prof. Dr.

Julgamento:

Prof. Dr.

Julgamento:
Instituição:

Assinatura:

Instituição:

Assinatura:

Instituição:

Assinatura: 


\section{Agradecimentos}

À Coordenação de Aperfeiçoamento de Pessoal de Nível Superior (CAPES) pela concessão de bolsa para realização desta tese.

À minha orientadora, professora doutora Elizabeth Harkot de La Taille pelos anos de dedicação.

À minha família, amigos e a todos que sabem que fizeram diferença.

Aos funcionários e funcionárias que tornaram meus anos de estudo possíveis.

À banca examinadora pela leitura. 


\section{Resumo}

ERNICA, R. R. Uma perspectiva intercultural sobre o jogar. Tese (Doutorado). Faculdade de Filosofia, Letras e Ciências Humanas, Universidade de São Paulo, 2019.

Esta tese trata de um tópico inquietante: o fato de que o acesso a jogos é barrado por um grande número de fatores que são, segundo as teorias mais proeminentes em ludologia, externos ao seu objeto de estudo e, portanto, não são considerados em sua definição base. Com isso em mente, nosso objetivo é discutir os termos em que uma definição mais amplo de jogos e do jogar pode ser alcançada ao se usar uma grade teórica que tem a diferença social no centro e que vê o processo de produção de sentido como algo mais complexo do que a mera extração de conteúdo de um objeto. Utilizamos os trabalhos de Ahmed (2006), Alcoff (2006), Fontanille (2015) and Groupe $\mu$ (2015) para problematizar as teorias de Bogost $(2006 ; 2007)$ e Sicart $(2011 ; 2014)$, e em seguida analisamos jogos populares como Final Fantasy $X$ e League of Legends para demonstrar nosso ponto de vista.

Palavras-chave: Jogos; Jogar; Semiótica; Ludologia. 


\begin{abstract}
ERNICA, R. R. An intercultural perspective on playing. Tese (Doutorado). Faculdade de Filosofia, Letras e Ciências Humanas, Universidade de São Paulo, 2019.

This dissertation is about an unsettling topic: the fact that access to play and games is gated by a great number of factors that are, according to the most prominent theories in game studies, is external to the object of their study and, therefore, is not considered in its core definition. With that in mind, our goal is to discuss the terms in which a broader definition of games and play can be achieved by using a theoretical framework that has social difference in its core and that views the meaning-making process as something more complex than the simple extraction of content from an object. We focus on the works of Ahmed (2006), Alcoff (2006), Fontanille (2015) and Groupe $\mu$ (2015) to review the theories of Bogost (2006; 2007) and Sicart (2011; 2014), and then proceed to the analysis of popular games such as Final Fantasy $X$ and League of Legends to demonstrate the merits of our point of view.
\end{abstract}

Keywords: Games; Play; Semiotics; Ludology. 


\section{Sumário}

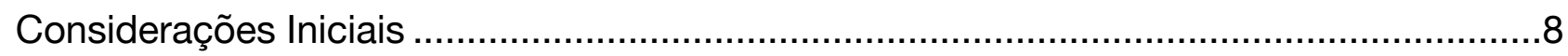

Capítulo 1 - A (in)definição de jogo entre ontologia e semiótica ...................................10

Capítulo 2 - A configuração semiótica do espaço.....................................................45

Capítulo 3 - Estereótipos, figurativização e mecânicas de jogo: uma isotopia restritiva ..87

Considerações Finais................................................................................. 146

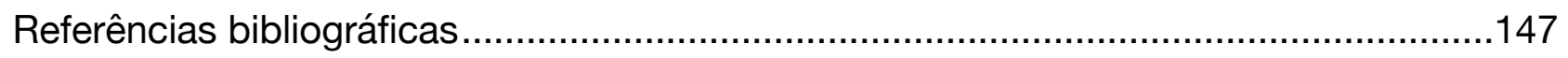




\section{Considerações Iniciais}

Se apenas uma palavra pudesse ser escolhida para descrever o percurso desta Tese, "sinuoso" seria talvez a escolha mais adequada. Marcado por diversos obstáculos, ora de ordem acadêmica, ora de ordem pessoal, o trabalho tomou corpo a partir de adaptações e desvios sem os quais não se poderia seguir. Em diversos aspectos, seguir significou reinventar-se; em outros, diminuir-se; em muitos, negar-se. Por isso, intitula-se "Ensaio" na medida em que não representa um trabalho cujo objetivo é apresentar uma discussão finalizada com uma solução aparente para um problema que se coloca; tratase, em vez disso, de um conjunto de ideias e reflexões cuja coesão e coerência não vêm do fato de confluírem para um fim textualmente explícito, mas sim de uma tentativa de expor camadas de um problema extremamente complexo: o fato de que $\mathrm{o}$ ato de jogar um jogo representa coisas distintas para jogadores diferentes.

Para muitos, é algo simples: o cartucho desliza para dentro do console com o mínimo de pressão. O botão de ligar é pressionado e a tela da TV passa a exibir cores e formas. É aí - e somente aí - que os limites do jogo começam e terminam; e é a partir disso que os estudos de jogos digitais se formam: das imagens que pulam, correm e golpeiam. O sentido de qualquer jogo se extrai disso e nada há além daquilo que se põe a ver quando o botão de ligar é pressionado, encerrando-se quando ele o é uma vez mais para desligar. Há, no entanto, mais que isso, e nessa zona que não cabe no cartucho esta Tese-Ensaio se insere.

Cada cartucho traz com ele uma história: alguns são comprados, outros alugados; há originais e piratas; há inclusive aqueles que são transportados às escondidas, pois jogar video game não é uma atividade para meninas. Nem toda TV é a mesma: há aquelas colocadas no quarto, dentre várias, e há aquelas que ficam na sala, a única da casa; há também as do vizinho que permite seu uso por um tempo ou as que ficam nos fundos da locadora, funcionando apenas pelo tempo que as moedas puderam comprar. A partir disso, vemos que nem todas as imagens na tela se exibem do mesmo modo para

todos os jogadores. A história do encontro entre jogador, cartucho, console e TV é variada, e ela importa.

Dividida em duas partes, uma teórica e a outra analítica, esta Tese-Ensaio se propõe inicialmente a refletir sobre o problema da definição de jogo e da maneira como 
ela é trabalhada em dois dos ramos mais populares dos game studies. Para isso, retomamos alguns conceitos-base e debatemos a questão ontológica a que essas correntes teóricas se dedicam, contrapondo nossa perspectiva mais alinhada com os desenvolvimentos da semiótica. Em seguida, ainda na primeira parte, discutiremos os conceitos de corpo e espaço como forma de expandir o referencial teórico anteriormente problematizado. Nosso objetivo é fornecer novos conceitos e relativizar categorias dos autores previamente citados de modo a obter uma base sobre a qual a análise das diferenças observadas nos mais diversos atos de jogar é possível; trata-se, em suma, de fazer tanto com que o conceito de "jogo" abarque coisas que normalmente lhe são consideradas alheias quanto com que o conceito de "jogar" não ignore o aparato formal normalmente associado à conceptualização de "jogo".

A segunda parte, mais curta, será dedicada à análise ilustrativa do discurso lúdico em si, demonstrando como a indústria, com sua retórica própria, cria um sistema tóxico em que a exclusão é fomentada por meio de uma retro-alimentação bastante peculiar: jogos figurativizam grupos minoritários como inferiores, criando uma cultura de exclusão e preconceito em que jogadores que pertencem a esses grupos não conseguem se incluir; a indústria de jogos atrai uma força de trabalho composta majoritariamente por gamers, os quais são educados ludicamente nessa cultura, e, consequentemente, criam jogos que reproduzem e reforçam a retórica de exclusão. O objetivo das análises é complementar a discussão teórica, demonstrando como os conceitos mainstream dos game studies, por mais válidos e importantes que sejam, não conseguem dar conta sozinhos da complexidade do fenômeno lúdico quando abordado sob uma ótica da multiplicidade de experiências. 
Capítulo 1

\section{A (in)definição de jogo entre ontologia e semiótica}

"O ponto de vista define o objeto" científico, talvez uma das que ilustre melhor o caráter criador que determinada abordagem tem em relação a um dado do mundo, considerado passível de análise; prévio ao ponto de vista, ao verbo fundador de uma epistemologia, o objeto, seja ele qual for, inexiste cientificamente: nomear, classificar e decompor são o que dão forma a algo que antes, ao menos enquanto fonte de conhecimento, não tinha razão de ser. Nesse sentido, podemos argumentar que a ciência, ao invés de se formar a partir do objeto, forma-se ao formá-lo. A partir dessa linha de raciocínio, esta Primeira Parte focará não tanto em definir o que vem a ser um jogo, mas antes em analisar o percurso tomado pelo que se considera a linha mainstream de ludologia na definição de seu objeto de estudo.

A fundação dessa corrente se identifica com a criação do journal internacional Game Studies (em 2001), e com o lançamento do livro Rules of Play e de The Game Design Reader: A Rules of Play Anthology, compêndio de ensaios que o complementa (SALEN E ZIMMERMAN, 2004; 2006), na medida em que são considerados pela comunidade como pioneiros em seu campo, por originalidade, qualidade, minúcia e extensão. $^{2}$

Esse enfoque se justifica porque, mesmo sem menção direta, é essa visada que dá base às perspectivas formalistas e estéticas, que são nosso ponto de partida teórico. Além disso, o trabalho de Salen e Zimmerman (2004) é, em contexto brasileiro, bastante difundido e largamente utilizado como referência bibliográfica; sendo assim, torna-se necessário revisar o modo como a disciplina se estabeleceu e apontar os desenvolvimentos mais recentes derivados de sua linha de pensamento, os quais, ao menos aqui, parecem não ser tão utilizados.

\footnotetext{
${ }^{1}$ Frase atribuída a Ferdinand de Saussure, que aparece no Curso de Linguística Geral, publicação baseada em anotações de seus discípulos.

${ }^{2}$ Cf. as notas introdutórias ao livro e ao compêndio de Salen e Zimmerman.
} 
O estabelecimento de fundadores que dão coerência a uma disciplina tem um duplo movimento, pois não só cria um campo de conhecimento autônomo a partir de um conjunto de ideias, como também direciona a leitura, sob o rótulo de precursores, dos trabalhos em que essa teorização se baseia; em suma, o estatuto de fundador funciona como um divisor de águas entre a disciplina e os estudos dispersos que, apesar de apresentarem reflexões sobre o tema (já que o objeto inexiste previamente à sua teorização), ainda não se configuram como pertencentes a ela - falta-lhes algo, muito embora sejam considerados fundamentais. O gênero "compêndio" é especialmente significativo nesse caso, pois os precursores não se limitam a citações pontuais, sendo apresentados em uma totalidade aos leitores.

Em seguida, focaremos em definições correntes de jogo, as quais representam de modo bastante objetivo o caráter formal e abstracionista que direcionou a formação da definição "clássica" de jogo em ludologia, representando uma redução das perspectivas anteriores a uma fórmula. É importante salientar que o uso do termo "redução" não tem por base uma avaliação negativa de nossa parte, uma vez que a redução formal e abstrata não constitui per se um problema, e pode perfeitamente figurar como um modelo de investigação dos traços pertinentes ${ }^{3}$ de um objeto.

\section{Os precursores}

Dentre os diversos textos possíveis, destacaremos apenas três (todos presentes no compêndio organizado por Salen e Zimmerman (2006)): os de Huizinga, Caillois e Crawford. Os dois primeiros são considerados clássicos nas ciências humanas e são largamente utilizados como referência primária para se falar de jogo em contextos os mais diversos; o último trabalho mencionado - escrito no início da década de 80, logo após a expansão dos sistemas domésticos de entretenimento digital na década de 70 (dentre os quais o console Atari VCS, posteriormente nomeado Atari 2600 talvez seja o mais famoso) - é cronologicamente o primeiro texto que se dispõe a sistematizar conceitos e técnicas de design de jogos digitais.

\footnotetext{
${ }^{3} \mathrm{O}$ conceito de pertinência aqui utilizado diz respeito à "regra da descrição científica [...], segundo a qual só devem ser tomadas em consideração, entre as numerosas determinações (ou traços distintivos) possíveis de um objeto, as que são necessárias e suficientes para esgotar sua definição", ou seja, trata-se da análise apenas do que interessa a um ponto de vista específico, das propriedades que permitem que um objeto se distinga dos demais (GREIMAS E COURTÉS, 2012, p. 369).
} 


\section{Huizinga}

[Jogar] é, na verdade, sair da vida "real" e entrar em uma esfera temporária de atividade com uma disposição própria a si mesma. O quão sedimentada essa percepção está na alma da criança é ilustrada de modo contundente pela seguinte história, contada a mim pelo pai do menino em questão. Ele encontrou seu filho de quatro anos sentado à frente de uma fila de cadeiras, brincando de "trens". Quando ele o abraçou, o menino disse "não beije o maquinário, papai, ou os vagões não vão pensar que é real".

[Play] is rather a stepping out of "real" life into a temporary sphere of activity with a disposition all of its own. How deep-seated this awareness is in the child's soul is strikingly illustrated by the following story, told to me by the father of the boy in question. He found his four-year-old son sitting at the front of a row of chairs, playing 'trains'. As he hugged him the boy said: "Don't kiss the engine, Daddy, or the carriages won't think it's real". (HUIZINGA, 1949, p. 8)

A tese central de Huizinga é a de que o jogo representa, não um produto cultural, mas a origem de toda cultura: ele identifica nos animais e no homem o mesmo fenômeno, e portanto o localiza no ponto inicial do processo de culturalização humana. $\mathrm{O}$ núcleo do jogo é, para Huizinga, a "diversão" (fun), conceito indefinível e que não deve ser confundido com falta de seriedade, uma vez que instituições sérias dele derivam e até mesmo ele pode ser encarado sem leveza. A tese de Huizinga coloca, portanto, o jogo na gênese de tudo que é humano em termos antropológicos, sociológicos e, até mesmo, linguísticos.

\section{Caillois}

Os jogos disciplinam os instintos e lhes impõem uma existência institucional. No momento em que Ihes conferem uma satisfação formal e limitada, educam-nos, fertilizam-nos e vacinam a alma contra sua virulência. Ao mesmo tempo, tornamIhes próprios a contribuir de modo útil a enriquecer e fixar os estilos das culturas.

Les jeux disciplinent les instincts et leur imposent une existence institutionnelle. Dans le moment où ils leur accordent une satisfaction formelle et limitée, ils les éduquent, les fertilisent et vaccinent l'âme contre leur virulence. En même temps, 
ils les rendent propres à contribuer utilement à enrichir et à fixer les styles des cultures. (CAILLOIS, 2000, p. 121)

Partindo de Huizinga, Caillois segue tratando o jogo em relação à cultura, mas de um modo diferente: para o francês, há uma pulsão, denominada paidia, que diz respeito a diversos comportamentos humanos potencialmente destrutivos, tais como a agressividade, o desejo de inebriar-se e perder o controle, e a propensão a assumir personalidades diversas; a paidia é culturalmente controlada por um conjunto de regras e convenções - o chamado ludus - que circunscrevem cada um de seus aspectos a uma atividade socialmente aceitável, o jogo: a agressividade é controlada aceita na competição de força ou destreza (agon); perder o controle dos próprios sentidos ou do destino é o que nos move a entrar em uma montanha russa (ilinx) ou a apostar no carteado (alea); e, por fim, a vontade de ser outro nos leva ao teatro (mimicry). Caillois, portanto, não busca a origem primordial da cultura no jogo, mas the confere papel central na civilização humana, na criação de instituições públicas e, por consequência, na manutenção de um contrato social.

\section{Crawford}

Embora melhorias tecnológicas certamente continuarão, já não somos mais prejudicados pelas limitações de equipamento. Nosso problema principal é que temos pouca teoria em que basear nossos esforços. Nós não sabemos bem o que é um jogo, ou por que as pessoas jogam jogos, ou o que faz um jogo ser ótimo. Arte de verdade por meio de jogos de computador é algo alcançável, mas jamais o será enquanto não tivermos uma via de compreensão. Equipamentos novos e melhores aprimorarão nossos jogos, mas não irão garantir nosso sucesso artístico além do que o desenvolvimento das orquestras garantiu a existência de Beethoven. Estamos muito longe de ter um jogo de computador comparável a uma peça de Shakespeare, uma sinfonia de Tchaikovsky, ou um auto-retrato de Van Gogh. Cada um desses artistas apoiou-se nos ombros de artistas precedentes que se lançaram em um mundo inexplorado e mapearam seus territórios para que artistas posteriores pudessem construir seu trabalho e alcançar coisas maiores. Nós, desenvolvedores de jogos de computador, devemos juntar nossos ombros para que nossos sucessores possam alçar-se sobre eles. Este livro é minha contribuição a essa empreitada. 
While technological improvements will surely continue, we are no longer hampered primarily by the limitations of the hardware. Our primary problem is that we have little theory on which to base our efforts. We don't really know what a game is, or why people play games, or what makes a game great. Real art through computer games is achievable, but it will never be achieved so long as we have no path to understanding. We need to establish our principles of aesthetics, a framework for criticism, and a model for development. New and better hardware will improve our games, but it will not guarantee our artistic success any more than the development of orchestras guaranteed the appearance of Beethoven. We are a long way from a computer game comparable to a Shakespeare play, a Tchaikowsky symphony, or a Van Gogh self portrait. Each of these artists stood on the shoulders of earlier artists who plunged into an unexplored world and mapped out its territories so that later artists could build on their work and achieve greater things. We computer game designers must put our shoulders together so that our successors may stand on top of them. This book is my contribution to that enterprise. (CRAWFORD, 1997, p. 4)

Crawford trata especificamente de jogos digitais e do seu potencial estético, muito embora embora declare em seu trabalho que o jogo é essencial à evolução e constituição do homem - em especial no que diz respeito à aprendizagem -, alinhando-se, assim, a Huizinga e Caillois. Para Crawford, o computador ganha potencial ao alinhar processamento a renderização ${ }^{4}$ visual e sonora, possibilitando expressão artística e lúdica; considerando que isso não é explorado com maturidade, Crawford coloca como objetivo de seu trabalho analisar a produção corrente, determinando os principais gêneros de jogos eletrônicos e os temas a eles associados, de modo a fornecer as bases de uma formalização da área de jogos digitais - inclusive em sua metalinguagem -, a qual é necessária, segundo ele, para seu crescimento enquanto arte. Há, portanto, em Crawford a noção de que jogos são um objeto, passível de ser comercializado ou distribuído, e dotado de potencial expressivo.

\footnotetext{
${ }^{4} \mathrm{Em}$ inglês, o verbo to render significa "fazer com que algo fique em um estado específico", e é utilizado para descrever, por exemplo, o desenho arquitetônico, que traduz um objeto tridimensional para uma representação bidimensional no papel. Nessa esteira, "renderizar" é um anglicismo comumente usado em português do Brasil para designar o processo pelo qual um computador traduz dados armazenados em código binário para uma materialidade visual ou sonora.
} 


\section{As definições standard}

Neste tópico, discutiremos brevemente as definições propostas por Salen e Zimmerman (2004) e Juul (2005), as quais são bastante difundidas nos estudos brasileiros.

\section{Salen e Zimmerman; Juul}

As definições dos autores são as seguintes:

Um jogo é um sistema em que jogadores se engajam em um conflito artificial, definido por regras, e que produz um resultado quantificável.

A game is a system in which players engage in an artificial conflict, defined by rules, that results in a quantifiable outcome. (SALEN E ZIMMERMAN, 2004)

Um jogo é um sistema baseado em regras com um resultado variável e quantificável, em que valores diferentes são atribuídos a resultados diferentes, o jogador empreende esforço para influenciar esse resultado, o jogador se sente emocionalmente ligado ao resultado, e as consequências da atividade são negociáveis.

A game is a rule-based system with a variable and quantifiable outcome, where different outcomes are assigned different values, the player exerts effort in order to influence the outcome, the player feels emotionally attached to the outcome, and the consequences of the activity are negotiable. (JUUL, 2005)

Em ambas, a noção de sistema, delineada por alguns precursores (incluindo Crawford), é resgatada e funciona como espinha dorsal de todo o objeto. Um jogo é, de acordo com essas definições, não uma coisa, mas uma maneira de organizar coisas, podendo prescindir delas para existir. Isso se verifica quando trazemos para a discussão um exemplo como o do xadrez, que não só partilha um tabuleiro com o jogo de damas, como pode se apartar inclusive de qualquer suporte físico para ser jogado: reduzindo-se 
as peças a suas funções e as posições no tabuleiro a coordenadas, é possível jogar xadrez mentalmente - modalidade conhecida como "xadrez às cegas".

No caso de Salen e Zimmerman (2004), as esferas do "jogar" e da "cultura" são consideradas importantes, mas o jogo, enquanto estrutura, pode prescindir de ambas para existir em si mesmo; ou seja, embora existam, não constituem o núcleo do fenômeno. Para Juul (2005), o aspecto ficcional e narrativo pode ser isolado do sistema de regras, alocado para ele no domínio do real, colocando o jogo em uma espécie de limiar entre ficção e realidade, em que esta é muitas vezes contradita por aquela. O que nos interessa é que em ambos os casos o sistema ganha autonomia em relação aos demais aspectos, o que não se verifica necessariamente nas abordagens precursoras; trata-se de uma busca por ontologia baseada num processo de abstração, de retirada de camadas de complexidade.

Sob nossa perspectiva, tal abordagem não se sustenta, uma vez que, enquanto semiose, ela não pode ser generalizada e aplicada a jogos como o futebol ou vôlei, que não podem se abster de elementos físicos básicos como a bola ou a delimitação para determinar quando se marca ou não um ponto. Sendo assim, o que se verifica é que, muito embora um jogo não possa ser totalmente reduzido aos elementos físicos que o compõem, a estrutura sistêmica sozinha não pode ser deles isolada - a sistematização deve ocorrer em um espaço. Ou melhor: é preciso que um espaço seja sistematizado.

Um exemplo simples pode ser encontrado na descrição de uma brincadeira infantil de apostar corrida: "vamos ver quem chega na esquina primeiro, sem sair da calçada"; elementos comuns do espaço (a esquina, o ponto onde se está, a calçada e a rua) tornam-se pontos de referência conectados por relações de oposição e por um objetivo final que lhes da coerência.

Para que isso aconteça, não só o conjunto de regras precisa existir, como ele deve ser efetivamente aplicado e aceito pelos jogadores. No caso do futebol, a figura do árbitro garante a adesão dos participantes ao sistema que se projeta não só sobre elementos como bola e campo, mas também sobre os próprios corpos dos jogadores, uma vez que a relação entre pés e bola é completamente diferente da relação entre mãos e bola. Qualquer desvio pode inviabilizar a realização do jogo, o que problematiza as definições propostas acima e requer que os participantes do evento, sua disposição em estar no jogo, sejam colocados no cerne da definição; não há, portanto, como retirar da constituição básica do objeto seu aspecto intersubjetivo e social - ou, ainda melhor, 
cultural. Em suma, um jogo poderia ser definido de maneira menos abstrata como um evento em que pessoas sistematizam um espaço por meio de regras de conduta e aderem a essas regras de modo a garantir o bom funcionamento da atividade; é dessa definição básica que partiremos.

No caso dos jogos digitais, a dinâmica é bastante parecida, muito embora as regras que regem o sistema estejam programadas no software independente do usuário. Em Tetris, por exemplo, é impossível ao jogador alterar a dinâmica das peças que avançam na tela, bem como as condições em que as linhas desaparecem. Apesar disso, sem que o jogador compreenda o sistema e faça sua projeção no espaço, o jogo não se torna possível: caso não se entenda como tudo funciona, quais são os objetivos e condições de vitória, não pode haver jogo; é preciso que aquilo que é mostrado na tela seja coerentemente interpretado.

Fora isso, a questão da aceitação ainda permanece: um jogador que use Tetris como plataforma eletrônica para fazer desenhos não está, necessariamente, jogando, mas utilizando o ambiente digital, com todas as suas regras, para realizar uma atividade que nada tem a ver com o propósito original daquele software específico. Mais que isso: caso o jogador considere o ato de desenhar como um desafio em si mesmo, é possível argumentar que o espaço foi sistematizado de modo distinto daquele proposto pelos desenvolvedores, dando origem a um outro jogo completamente diferente. Sendo assim, argumentamos que, mesmo no caso digital, a definição centrada no jogador ainda se sustenta.

Estender essa definição aos jogos digitais é importante para entender o processo de construção desse meio como linguagem, como um evento semiótico. Desde sua criação na década de 60 como software de teste para supercomputadores até os dias atuais, os jogos digitais transformaram-se imensamente a ponto de um produto vendido no início dos anos 80 parecer algo completamente diferente e não relacionado com um lançamento de 2019. Considerar que a evolução (no sentido tecnológico) dessa linguagem se deu como um processo linear desvinculado dos jogadores é absurdo ${ }^{5}$, uma

\footnotetext{
${ }^{5}$ Essa questão não é completamente desconhecida e ignorada pelos autores, cujas ideias foram aqui expostas de modo extremamente sumário. Juul, por exemplo, dedica seu livro A Casual Revolution (2010) à "revolução" desencadeada em grande pelo console Wii, desenvolvido pela empresa japonesa Nintendo, que resgatou na década passada modos de jogar e de desenvolver jogos presentes na década de 70, os quais foram progressivamente "esquecidos" nas décadas de 80 e 90 devido ao foco da indústria no público masculino adolescente, privilegiando o jogador solitário capaz de dedicar diversas horas seguidas ao ato de jogar. Desconhecemos, no entanto, uma teorização que coloque o peso do jogador de modo
} 
vez que, para obter sucesso não apenas comercial, mas enquanto evento-jogo - i.e., garantir que o usuário do software consiga sistematizar o espaço e queira aderir às regras -, os desenvolvedores precisam empenhar-se em criar meios de organização do espaço virtual eficientes o bastante para veicular as regras sistêmicas que regem o software de computador, e que sejam também atraentes a ponto de despertar o desejo de jogar. Em suma, um jogo tem de ser visualmente eficiente, esteticamente agradável e divertido o bastante para que os jogadores possam querer jogar, entender como se joga e sentir prazer enquanto o fazem; o usuário-consumidor é, portanto, parte integrante do processo de evolução dessa linguagem, reforçando sua importância como cerne da definição mesma de jogo.

\section{As definições correntes}

Embora a disciplina seja múltipla, pode-se argumentar que há duas correntes dominantes na disciplina, a retórica procedural, cuja figura proeminente é lan Bogost, e o que chamaremos aqui de estética do jogar, trabalhada sobretudo por Miguel Sicart. 0 contraste entre as abordagens é claro e, inclusive, declarado: Sicart, em 2011, publicou um artigo intitulado Against Procedurality ${ }^{6}$, em que Bogost é textualmente criticado muito embora suas contribuições à área sejam reconhecidas, sobretudo a partir dos estudos presentes em dois de seus livros: Unit Operations (2006) e Persuasive Games (2007). A contenda do artigo é expandida e elaborada de modo mais claro em Play Matters (SICART, 2014), livro que advoga enfaticamente por uma mudança de perspectiva no tratamento da questão do jogar, a ponto de ser classificado como um manifesto por Sebastian Deterding em uma resenha ${ }^{7}$.

Mesmo sem as menções explícitas, a polarização das duas abordagens seria clara pelo enfoque de análise: enquanto a retórica procedural foca nos elementos formais e abstratos dos jogos, os quais carregam em si mesmos o sentido que os jogadores devem deles extrair, a estética do jogar vê o lúdico (playfulness) como uma força de

orgânico dentro da definição própria de jogo, estabelecendo-o como um evento centrado em trocas semióticas entre corpos encarnados, ou seja, pessoas históricas e socialmente colocadas no mundo. $\mathrm{Na}$ versão final da tese, a discussão será feita de modo completo, considerando todas as nuanças.

${ }^{6}$ Against Procedurality. Game Studies, volume 11, edição 3, dezembro. 2011.

${ }^{7}$ A Manifesto, With Footnotes. A Review of Miguel Sicart's "Play Matters". Game Studies, volume 15, edição 1, julho. 2015. 
criação (artística) que invade espaços (sejam eles jogos ou não) e, ao fazê-lo, gera sentido. Em suma, a primeira centraliza o processo de significação no objeto, enquanto a segunda o faz em sua apropriação subjetiva.

Ambos os viéses têm como base um largo arcabouço teórico, que perpassa disciplinas diversas, dentre as quais a semiótica está presente; no entanto, a utilização se resume a conceitos gerais extraídos de fontes como Saussure e Peirce, que, por mais importantes que sejam, não representam as discussões mais atuais feitas na área. Sendo assim, a linha-guia de nossa discussão das correntes ludológicas supracitadas será a concepção do processo de significação, fundamental para a polarização radical; como base, utilizaremos sobretudo o trabalho do Groupe $\mu$ (2015).

Em seguida, proporemos uma aproximação dos dois viéses a partir da concepção do fazer científico que lhes dá base: ambos pressupõem a possibilidade de abstrair sujeito e objeto das condições materiais que os cercam; não questionam quem, como e quando se joga - pontos fundamentais para a semiótica atual, na medida em que são um dos fatores determinantes do processo de significação. Tanto Bogost quanto Sicart pressupõem-se capazes de chegar ao núcleo definidor de seus objetos, o qual independe de contexto e é hierarquicamente superior aos demais elementos.

Essa postura desencadeia uma aproximação ontológica e normativa dos objetos, muito embora nenhum dos autores afirme estar em busca de uma ontologia - Bogost (2006), inclusive, coloca essa questão fora de sua discussão. No entanto, tanto um quanto o outro adotam um ponto de vista totalizante, o qual, segundo os teóricos decoloniais Castro-Goméz e Grosfoguel (2007), está ligado ao método cartesiano de ciência, abstracionista por excelência.

A partir disso, demonstraremos que, muito embora haja ganhos teóricos evidentes a partir da adoção de tal epistemologia, ela não consegue dar conta de todas as variáveis que interagem no processo semiótico; em suma, a materialidade, tanto do sujeito quanto do objeto, se impõe, trazendo o particular que localiza o universal, bem como o parcial que nos impede de absorver a totalidade. Trata-se de uma postura acerca da ludologia que considera o sujeito como um corpo de fato, dotado de órgãos sensoriais, portador de uma história e membro de um grupo cultural, e não meramente uma instância discursiva e abstrata evocada como puro artifício retórico. 


\section{Proceduralidade e estética do jogar: considerações iniciais}

Esta seção vai expor, separadamente, as abordagens de lan Bogost e Miguel Sicart, ao mesmo tempo em que as revisa criticamente por meio da semiótica. Nossa leitura classifica ambas como ontológicas, na medida em que buscam o núcleo ou a essência daquilo que focam - o jogo, no caso de Bogost, e o jogar, no caso de Sicart. $\mathrm{O}$ contraste com um ponto de vista semiótico será feito na próxima seção.

\section{Retórica procedural}

O princípio de retórica procedural aparece em Bogost (2007) a partir de sua teoria das operações (2006), que possibilita analisar qualquer tipo de produto cultural como um conjunto formal de relações entre unidades de sentido encapsulado que se organizam de modo emergente sem um princípio estruturante hierarquicamente superior - uma organização bottom-up, e não top-down. Essas operações unitárias correspondem a uma redução algorítmica de comportamentos, que podem variar desde uma ação simples como abrir uma porta até algo mais complexo, como é o caso da análise de Bogost do "encontro fortuito" apontado como central tanto ao poema "A une passante" de Baudelaire quanto à expansão Hot Date, do jogo The Sims; a extração de sentido se daria quando o leitor/jogador abstrai essas operações pela leitura ou experiência. Sendo jogos digitais objetos computadorizados por meio de algoritmos, eles representam 0 meio em que as operações aparecem mais expressivamente.

O nome "procedural" é emprestado de Murray (1997), que identifica nessa simulação de comportamentos e ações o potencial expressivo do computador: em vez de desenhar uma situação acabada para apresentá-la, autores digitais desenvolveriam procedimentos que podem ser utilizados de modo mais ou menos livre, a depender das restrições autorais, para gerar situações. Como seu interesse é, primariamente, literário, Murray busca exemplos de usos narrativos desse potencial, e embasa sua factibilidade na possibilidade de redução do conceito de narratividade a unidades mínimas, as quais ela identifica na obra de Propp em uma seção sobre algoritmos narrativos (pp. 195-197).

Retornando a Bogost (2006; 2007), gostaríamos de salientar que o aspecto retórico diz respeito ao que ele chama de "brecha de simulação" (simulation gap): um modelo subjetivo presente na leitura que o jogador faz do sistema programado do jogo. 
Sendo este um conjunto de procedimentos, a brecha de simulação diz respeito à distância entre a subjetividade, que faz suposições a respeito do sistema, e aquilo que ele é em si. O autor aproxima esse aspecto ao entimema, que consiste na elisão de uma das partes de uma premissa a qual deve ser pressuposta para que a argumentação faça sentido; no caso procedural, a omissão na simulação de determinados aspectos do mundo real precisa ser percebida e pressuposta pelo usuário, que nessa brecha identifica o caráter ideológico das seleções feitas pelos desenvolvedores e, a partir disso, extrai o argumento retórico do jogo.

O objetivo da discussão dessa retórica é fornecer as bases de um letramento crítico desse potencial, de modo a permitir não só que desenvolvedores encapsulem sentido de modo mais eficiente, mas também que jogadores o extraiam de modo mais adequado possível. Desse modo, os jogos poderiam tornar-se um meio mais eficaz para compreender questões políticas e sociais, uma vez que a participação ativa do jogador e a variabilidade de resultados lhe são intrínsecas. Essa preocupação com o aspecto persuasivo do jogo (2007) vai ao encontro da perspectiva comparativa apresentada na teorização das operações unitárias (2006), cujo intuito era demonstrar que o poder expressivo do meio era comparável - e, em alguns casos, superior - ao das artes tradicionais, como literatura e cinema; trata-se de uma postura programática, um desejo expresso de que os jogos sejam (vistos como) mais do que mero entretenimento Bogost é, além de acadêmico, um designer e diversos dos exemplos citados no livro para ilustrar seus conceitos foram desenvolvidos por ele mesmo, inclusive os ruins.

Essa visada formalista também norteia trabalhos mais recentes de Bogost (2011), em que a materialidade do jogo (i.e., gráficos, som, sensação tátil do contato com controladores) é, por vezes, descartada ou pelo menos grandemente diminuída para destacar o papel dos procedimentos e sua retórica. De acordo com ele, a decisão de deixar de lado a importância desses aspectos é estética: "reduzir a obsessão dos jogadores com a decoração realça a experiência dos processos e ainda permite que as imagens, sons e textos clarifiquem de modo significante a ficção do tema do jogo"8 (grifos nossos) O material é, portanto, acessório, servindo para clarificar a ficção do jogo, mas não constituindo seu núcleo significante, sua condição sine qua non; essa posição ecoa as críticas feitas em trabalhos anteriores (2007, sobretudo) a jogos que se apoiam

\footnotetext{
8 "reducing the player obsession with decoration underscores the experience of processes while still allowing image, sound, and text to meaningfully clarify the fiction of the game's theme."
} 
em retóricas não-procedurais para veicularem seus argumentos - os aspectos materiais são considerados apenas no que é minimamente necessário para que a interação com o sistema ocorra.

Tendo exposto brevemente os pressupostos, o que nos interessa aqui é o fato de que a teoria bogostiana trata da questão do sentido como algo que reside no objeto e pode ser acessado por meio do processo de abstração. O referencial teórico para essas afirmações perpassa diversos autores de vários campos (filosofia, matemática, antropologia), dentre os quais destacaremos a herança linguística saussuriana e sua definição de valor diferencial: cada elemento dentro do sistema se define pelo contraste com os demais, sendo aquilo que os demais não são. Como é conhecido, a perspectiva saussuriana separa a estrutura sistêmica abstrata, denominada langue, de sua substância efetivamente realizada, parole, colocando apenas a primeira como objeto de estudo, primeiro ao menos, da ciência linguística; essa visão reaparece em outros teóricos estruturalistas, figurando na definição hjelmleviana de função semiótica, cujos funtivos, expressão e conteúdo, encontram-se subdivididos em forma e substância, dos quais apenas a primeira é destacada como objeto de estudo.

Trata-se de duas perspectivas formalistas de sentido, que o situam em um sistema de relações negativas cuja alocação não se encontra claramente definida: diferentemente de Bogost (2006; 2007), não se afirma categoricamente na linguística que tal estrutura faça parte do objeto ou se ela seria uma projeção absoluta do sujeito; ela é definida pelo estruturalismo saussuriano como social, não pertencente a nenhum sujeito em específico. A pressuposição de um acordo intersubjetivo - que subjaz à ideia de um sistema semiótico social - aponta, porém, para a externalidade do sistema em relação ao mundo na medida em que a arbitrariedade de um tal sistema cria barreiras entre ele e a materialidade do mundo natural (cf. GROUPE $\mu, 2015$, p. 18-9; 23-9). Essa dualidade não escapa a Greimas e Courtés (2012), que a discutem no verbete "Imanência" de seu dicionário de semiótica:

O conceito de imanência participa, como um dos termos, da dicotomia imanência/manifestação, pressupondo a manifestação logicamente o que é manifestado, isto é, a forma semiótica imanente. A afirmação da imanência das estruturas semióticas levanta, então, um problema de ordem ontológica, relativo a seu modo de existência: da mesma forma como antes nos interrogamos, a propósito da dialética, se ela estava inscrita "nas coisas" ou "nos espíritos", o 
conhecimento das estruturas semióticas pode ser considerado quer como uma descrição, isto é, como uma simples explicitação das formas imanentes, quer como uma construção, já que o mundo é apenas estruturável, isto é, capaz de ser "enformado" pelo espírito humano. Parece-nos oportuno, para afastar da teoria semiótica qualquer discussão metafísica, contentarmo-nos com a colocação de certos conceitos operatórios, denominando universo semântico (o "há sentido") toda semiótica anteriormente à sua descrição, e objeto semiótico sua explicitação com o auxílio de uma metalinguagem (e construção de representação) construída. (p. 255)

O projeto teórico da semiótica greimasiana, que parte das definições de Saussure e Hjelmslev, é guiado por essa escolha de considerar as estruturas como imanentes ao objeto, uma postura próxima a de Bogost (2006; 2007). No entanto, mais recentemente, o Groupe $\mu$ (2015) retoma e expande a discussão desses dois princípios - a diferença e a imanência -, argumentando que a relação de diferença pressupõe a de identidade (o que, segundo o Groupe, não escapava a Greimas), na medida em que, por mais contrastantes que sejam, os elementos envolvidos na operação entram em conjunção naturalmente, a partir desse envolvimento (pp. 21-22); ademais, a oposição não se encontra no objeto, e sim no aparelho perceptivo sujeito, que em vez de depreender uma estrutura, realiza uma estruturação do mundo perceptível na ocasião da percepção:

se o céu se opõe perceptualmente à terra, essas duas entidades não são, todas as duas, menos percebidas visualmente. $\mathbf{O}$ mundo natural apresenta-se assim como uma matéria única, sobre a qual se coloca nossa empreitada de estruturação e formalização, geradora do sentido.

si le ciel s'oppose perceptuellement à la terre, ces deux entités n'en sont pas moins toutes deux visuellement perçues. Le monde naturel présente ainsi une matière unique, sur laquelle porte notre entreprise de structuration et de formalisation, géneratrice du sens. (Idem, p. 22, realces nossos)

Portanto, se para Bogost (2007) o valor diferencial é utilizado como argumento para uma abordagem que extrai sentido de uma estrutura existente no objeto, os desenvolvimentos mais atuais da semiótica parecem caminhar para uma abordagem do conceito como uma espécie interpretação do sujeito sobre o mundo, afastando-se da tese de que a materialidade é uma manifestação de uma forma imanente a ela e 
aproximando-se da leitura contrária, de que a imanência é da ordem do sujeito enquanto ser do mundo, o que nos leva a alterar substancialmente a relação hierárquica entre ambos os termos: se na leitura bogostiana (e "standard" na semiótica francesa) a matéria pressupõe a estrutura, o estado atual da questão leva a crer que a estruturação pressupõe a materialidade; nesse sentido, o princípio de oposição viria do encontro, estando, de certa maneira, fora do mundo e, assim, ganhando valor instrumental para sua semiotização (GROUPE $\mu, 2015$, p. 22).

Essa característica é trabalhada na semiótica peirceana (PEIRCE, 1977, passim) por meio dos conceitos de ícone e índice, definidos como quase signos na medida em que se baseiam não em uma pura associação da mente, mas em uma contiguidade evidente entre o material (representamen) e aquilo que é representado (objeto); no caso dos símbolos - cuja ligação entre o representamen e objeto é feita puramente pelo intermédio da mente -, o processo é considerado arbitrário, mas o elemento material não é menos importante, na medida em que apenas enquanto tal é capaz de desencadear o processo interpretante, como argumenta Santaella (2009) no trecho a seguir:

Para se entender o que é o objeto do signo, é preciso considerar que o signo não ocorre no vazio. Ele está enraizado num vastíssimo mundo de relações com outros signos, com tudo aquilo que muito amplamente chamamos de realidade. Ele está inserido, de modo direto ou indireto, no universo físico interagindo com outros existentes. Para ser signo, algo não deixa de ser ao mesmo tempo uma "coisa". Aliás, algo nem poderia funcionar como signo se não estivesse corporificado em uma "coisa". Mesmo que seja meramente sonhado, imaginado, alucinado, hipoteticamente criado no pensamento abstrato, há sempre algum tipo de materialidade em que o signo toma corpo. Isso significa que todo signo é, ao mesmo tempo, signo e coisa. Além disso, não existe uma separação rígida entre o mundo dos signos, de um lado, e o mundo das coisas, de outro, mas muito mais intersecções, sobreposições e trocas infinitamente variáveis, de modo que aquilo que, num determinado momento, não passa de uma "coisa", no outro será signo e vice-versa. (p. 45, realces nossos)

Para Santaella, assim como para Peirce (1977), o processo signico é sempre desencadeado a partir de uma concretude, e é sediado em uma mente, o que elucida a última parte destacada no trecho supracitado: algo pode permanecer "coisa" na medida 
em que, longe do crivo da mente, a significação não se dá, e o processo ocorreria apenas quando a "coisa" é percebida e o signo se desencadeia. No entanto, para o Groupe $\mu$ (2015) não se trata de advogar por uma subjetividade absoluta em que o material é meramente gatilho de um processo puramente mental, mas de uma estrutura mista:

\begin{abstract}
Nesta hipótese, as estruturas depreendidas serão mistas: trazendo o traço do mundo natural, certamente, mas semiotizadas de modo estranho a ele e todas relativas a um ponto de vista humano. Aporia, na medida em que se finge ignorar que o humano em questão é parte integrante do mundo.
\end{abstract}

Dans cette hypothèse, les structures dégagées seraient mixtes: portant la trace du monde naturel, certes, mais sémiotisées de façon étrangère à lui et toutes relatives à un point de vue humain. Aporie, dans la mesure où l'on feint ici d'ignorer que l'humain en question est partie intégrante du monde. (Idem, p. 23)

Sendo o humano também parte do mundo material, as origens do princípio diferencial remontam ao modo de funcionamento dos órgãos sensoriais (pp. 23; 84-85), adaptado para a delimitação de zonas de variações de cor, formato, textura, som, sabor etc. Segundo o Groupe $\mu$ (Idem, passim), as diferenças percebidas são "exageradas", criando-se contrastes cada vez mais marcados e gerando áreas mais salientes que atraem nossa atenção e, por isso, tornam-se mais plenas de sentido. ${ }^{9}$

Isso leva a definições distintas tanto do conceito de percepção quanto de estrutura: “a percepção não é 'exterior' à estrutura. Pode-se, com efeito, entender por estrutura [...] o estabelecimento de relações entre entidades produzidas pela percepção"10 (Idem, p. 32) Esse mecanismo depende tanto da matéria quanto da cultura, uma vez que o modelo de semiose do Groupe $\mu$ pressupõe não só apreensão mas também ação transformadora, seja por intervenção direta, seja pela elaboração de sistemas semióticos que alongam o sentido produzido perceptivamente, refinando-o e complexificando-o cada vez mais.

\footnotetext{
${ }^{9}$ Retornaremos a essa questão posteriormente, sob um ângulo específico ao tratar do conceito de espaço.

10 "la perception n'est pas 'exterieure' à la structure. On peut en effet entendre par structure [...] la mise en relation d'entités produites par la perception."
} 
Sendo assim, Bogost (2006; 2007), muito embora traga contribuições valiosas acerca do jogo como uma estrutura pensada enquanto algoritmos e desenvolvida como uma atividade regida por procedimentos, baseia-se em uma noção problemática do que vem a ser semiótica e sentido, deixando de lado o sujeito. Essa constatação parece contraditória, tendo em vista que o conceito de brecha de simulação pressupõe a subjetividade, porém se trata de uma formulação arquetípica e descontextualizada: o Jogador é pressuposto em condições ideais, podendo talvez ser grafado com a primeira letra em caixa alta, uma espécie de entidade abstrata inclusa na teoria por convencionalidade ${ }^{11}$. Essa característica é apontada por Sicart (2011), e será discutida no próximo tópico.

\section{As questões da ludicidade}

O artigo de Sicart (2011) faz um balanço da abordagem proceduralista, apontando inicialmente seu valor:

[A]plicar essa linha de pensamento [proceduralismo] a jogos de computador inovou em pelo menos dois aspectos; primeiro, proveu um argumento àqueles que se dedicaram a considerar jogos de computador como meios de comunicação culturalmente válidos; e segundo, proveu um novo fundamento teórico baseado em uma abordagem multidisciplinar da disciplina de jogos de computador, do movimento de jogos sérios. O proceduralismo, em um só movimento, justificou a validade cultural dos jogos de computador ao prover uma base aos argumentos de excepcionalidade (jogos de computador como objetos culturais únicos e expressivos), e abriu a possibilidade de um novo ponto de vista sobre os jogos sérios que combinou abordagens de design com um forte discurso humanista.

[A]pplying this line of thought [proceduralism] to computer games innovated in at least two accounts: first, it provided an argument for those invested in considering computer games as a valid cultural means of communication; and second, it provided a new theoretical foundation,

\footnotetext{
${ }^{11}$ De modo muito similar ao que se pratica(va) nas vertentes greimasianas de semiótica com o conceito de "enunciação", sempre presumido mas estudado apenas nos traços considerados pertinentes ao texto enquanto estrutura.
} 
based on a multidisciplinary approach to computer games scholarship, to the serious games movement. Proceduralism both justified the cultural validity of computer games providing arguments for the exceptionality argument (computer games as unique, expressive cultural objects), and opened the possibility for a new take on serious games that combined design approaches with a strong humanist discourse.

Nesse sentido, os objetivos de Bogost (2006; 2007) parecem ter dado frutos, uma vez que Sicart (2011) fala dessas questões em retrospectiva. No entanto, muito embora haja contribuições, a instrumentalização excessiva do ato de jogar é vista como um grande problema dessa obsessão com a estrutura em detrimento do material:

Isto [o proceduralismo] leva a um entendimento do ato de jogar, e do lazer, como resultados mecânicos de processos; resultados que seguem o mesmo modelo de produção e consumo do trabalho: "O entretenimento no capitalismo tardio é a prolongação do trabalho (...) a mecanização tem tal poder sobre o lazer e a felicidade de um homem, e determina tão profundamente a manufatura de bens de entretenimento, que suas experiências são inevitavelmente afterimages ${ }^{12}$ do processo de trabalho em si" (Adorno e Horkheimer, p. 137). O proceduralismo, ao focar nos sistemas como centro da essência dos jogos e desconsiderar atos de jogar expressivos ou ineficientes, transforma o evento de jogar um jogo em uma ação similar ao trabalho, em trabalho com vistas a um resultado racional, decidido e predeterminado externamente, desenhado por outros que não os jogadores. $O$ ato de jogar torna-se externo ao jogador e ao contexto de jogo.

This [proceduralism] leads to an understanding of play, and leisure, as mechanical outcomes of processes; outcomes that follow the same production and consumption models than labor: "Amusement under late capitalism is the prolongation of work (...) mechanization has such power over a man's leisure and happiness, and so profoundly determines the manufacture of amusement goods, that his experiences are inevitably afterimages of the work process itself." (Adorno and Horheimer, p. 137). Proceduralism, with its call for systems at the core of the essence of games and its disregard for expressive or ineffective play, turns the act of

\footnotetext{
${ }^{12}$ Não há tradução do conceito para o português. Trata-se do fenômeno de preservação de uma imagem na retina mesmo após o estímulo físico não estar mais presente.
} 
playing a game into a labor-like action, into work towards an externally decided, predetermined, and rational outcome designed by others than the players. Play becomes external to the player and the play context.

O foco no aspecto procedural faz com que cada vez mais as ações sejam relegadas a um segundo plano e, com sua instrumentalização, os desvios causados pelos jogadores, suas interferências e desafios são considerados ruídos. "É quase como se os proceduralistas estivessem desenvolvendo contra $\mathrm{o}$ ato de jogar"13, afirma o autor. A postura proceduralista vai de encontro à nossa, uma vez que o ato de jogar representa a instância enunciativa, isto é, o local onde sujeito e software irão se encontrar, sendo este percebido, vivenciado e alterado neste encontro; a presunção de que a jogabilidade é instrumental, mero processo de extração, não dá conta da complexidade semiótica que descrevemos logo acima.

Ampliando sua crítica, Sicart (2014) se debruça sobre uma definição ampla do ato de jogar; trata-se de um modo de ser, estar e entender a nós mesmos e ao que nos cerca, e não algo ligado exclusivamente aos jogos e, portanto, aos sistemas formais que os definem proceduralmente: "Jogos não importam. Como na antiga fábula, somos os tolos olhando para o dedo quando alguém aponta para a lua. Jogos são o dedo; o jogar é a lua" ${ }^{14}$ (p. 2). Ele avança a discussão buscando, ironicamente, uma definição desvinculada de materialidade:

Para entender o que é o jogar, proponho uma teoria portável, ou uma retórica, do jogar. Em vez de derivar seu entendimento de um objeto ou atividade, como a guerra, os rituais, ou os jogos, eu vejo o jogar como uma ferramenta portável para o ser. Não é algo ligado a objetos mas sim trazido por pessoas às complexas interrelações com e entre as coisas que formam a vida cotidiana.

To understand what play is, I propose here a portable theory, or rhetoric, of play. Instead of deriving an understanding of play from a particular object or activity, like war, ritual, or games, I see play as a portable tool for

\footnotetext{
13 "It is almost as if proceduralists were designing against play"

14 "Games don't matter. Like in the old fable, we are the fools looking at the finger when someone points at the moon. Games are the finger; play is the moon"
} 
being. It is not tied to objects but brought by people to the complex interrelations with and between things that form daily life. (Ibidem)

Definida como atividade carnavalesca, o ato de jogar é apropriativo, invadindo contextos que podem não ter sido organizados para serem jogados; assim, o jogo modifica nosso modo de entender esses contextos, alterados pela intervenção do lúdico - encarada pelo autor como uma experiência estética e, em nossa leitura, semiótica.

Nossa crítica a Sicart se baseia nessa questão: a desmaterialização do ato de jogar, separando-o dos objetos que o compõem; uma espécie de essência, que remete à questão da ontologia, do ser do tópico em questão. Esse problema fica bastante visível ao se discutir a tese de Sicart em língua portuguesa, uma vez que a polissemia do termo "play" cria problemas de tradução: se optarmos por "jogar", palavra etimologicamente ligada a "jogo", desvalorizamos boa parte da argumentação do autor, a qual se funda na ligação etimológica em língua inglesa entre a palavra "play" e derivados como "playful", "playfulness" e pelo uso do verbo para designar diferentes atividades, tais quais "play with a doll/toy" - que em português traduziríamos por "brincar", atividade distinta do "jogar", sobretudo em contextos de esportes profissionais. Em suma, a abordagem de Sicart se baseia nessa polissemia, que, fora da língua e cultura anglófonas, pode simplesmente inexistir ou, no mínimo, ser radicalmente diferente; sendo assim, sua busca por uma essência é extremamente localizada histórica e culturalmente, muito embora tente atingir uma espécie de universalidade.

Há outro ponto problemático da teoria sicartiana de "play" (sobretudo o substrato que está relacionado a "game): o ato é, segundo o autor, dependente de regras, muito embora elas não sejam o elemento mais importante; o que importa, em contextos de "play", é a apropriação criativa. No entanto, Sicart não localiza culturalmente essa apropriação, que não pode ser efetuada de modo igual por todos, como bem demonstram os diversos exemplos de conflitos por espaço, seja físico ou institucional, travados por minorias diversas. Pensando em uma questão mais prática e diretamente ligada à questão dos jogos digitais, temos o problema da desigualdade econômica que impede que boa parte da população brasileira tenha acesso (irrestrito, ao menos) aos dispositivos tecnológicos necessários para jogar; em termos mais básicos, é impensável 
pensar em apropriação desvinculada de contexto em um país em que, na ocasião do censo de 2010, o acesso à energia elétrica ainda não era universal. ${ }^{15}$

Em termos gerais, Sicart representa um contraponto importante ao formalismo excessivo da corrente procedural, que considera o sentido de um jogo como algo intrínseco a um sistema formal abstrato e independente de qualquer contexto; porém, o autor parte para uma análise do jogar como apropriação que não faz uma discussão aprofundada acerca de quem se apropria, como, quando e quais as decorrências disso em culturas específicas. Essa lacuna é o mote para nossa discussão acerca dos limites da postura ontológica e universalista, que iniciaremos na próxima seção.

\section{Ultrapassando os limites da ontologia}

Nesta seção, vamos aproximar as duas leituras por meio de sua constituição ontológica e universalista, ao mesmo tempo em que buscaremos alternativas a essas leituras a partir das perspectivas semiótica e decolonial. Nosso objetivo é chegar a um tipo de leitura não excludente, e que leve em conta a materialidade, a polissemia e os conflitos inerentes ao contraste entre pontos de vista antagônicos, sem reduzir o objeto a apenas um deles.

\section{A semiótica como relativização da ontologia}

Para iniciar a discussão, faremos uma digressão - à primeira vista inusitada - de modo a expandir os limites da teorização aqui feita e iremos nos valer de um exemplo bastante saliente na contemporaneidade: o do estatuto semiótico dos alimentos. Nos últimos anos, assistimos à proliferação de publicações, programas televisivos e canais do YouTube dedicados ao seu preparo e consumo (adequados), incluindo competições altamente acirradas em formato de reality show, como o programa MasterChef, produzido no Brasil pela emissora Bandeirantes. Nesse contexto, programas de TV como o Bela Cozinha (GNT), comandado por Bela Gil - buscam aliar conceitos científicos do campo da nutrição com a chamada haute cuisine, desmistificando o senso comum de

\footnotetext{
${ }^{15} \mathrm{http} / / / w w w . b r a s i l . g o v . b r / i n f r a e s t r u t u r a / 2011 / 11 /$ energia-eletrica-chega-a-97-8-dos-domicilios-brasileirosmostra-censo-demografico (Acesso em Julho de 2019)
} 
que a atenção aos nutrientes deriva necessariamente em uma perda de qualidade gastronômica.

O que nos interessa particularmente nesses casos é a tentativa de balancear duas modalidades diferentes de tratamento dos alimentos: o primeiro diz respeito a uma leitura que tenta estabelecer sua essência e estrutura, identificando-os como um complexo químico-biológico cujo propósito é manter seres vivos funcionando da melhor maneira possível; o segundo foca em uma tradição milenar de preparo e consumo, mais preocupada com o modo como os alimentos interagem com nosso sentido gustativo e satisfazem desejos não relacionados diretamente à nutrição. Numa perspectiva estritamente científica, apenas o primeiro diria respeito ao que um alimento realmente é, ou seja, sua ontologia, e numa perspectiva teórica que aloca o sentido no objeto e que concebe um processo semiótico de extração, qualquer interpretação desviante ou não baseada nesse conhecimento formal seria, portanto, da ordem da falsidade.

No entanto, essa perspectiva ignora o fato de que o pão e o vinho precedem em muitos séculos a metalinguagem que explica seu processo de fermentação, e que, para algumas culturas, esses dois alimentos representam o corpo e o sangue de uma divindade feita homem, com a qual podemos ritualmente nos ligar por meio de sua ingestão. Embora ontologicamente adequada, a metalinguagem científica não dá conta de um processo interpretativo que, ao figurativizar o divino no alimento, dirige a vida de pessoas ao redor do mundo há centenas de anos, determinando suas escolhas e servindo de base a obras de arte que facilmente classificaríamos fora do campo alimentar, como $A$ Última Ceia, de Leonardo da Vinci, e o poema "Salmo $\mathrm{n}^{\circ} 3^{\text {" de Murilo }}$ Mendes, do livro Tempo e Eternidade de 1934:

Eu te proclamo grande, admirável,

Não porque fizeste o sol para presidir o dia

E as estrelas para presidirem a noite;

Não porque fizeste a terra e tudo que se contém nela,

Frutos do campo, flores, cinemas e locomotivas;

Não porque fizeste o mar e tudo que se contém nele,

Seus animais, suas plantas, seus submarinos, suas sereias:

Eu te proclamo grande e admirável eternamente

Porque te fazes minúsculo na eucaristia,

Tanto assim que qualquer um, mesmo frágil, te contém. 
A redução da hóstia a um tipo de carboidrato não nos parece relevante ao poema acima, que trata de uma outra concepção - ritualística, no caso - do processo alimentar, e coloca Murilo Mendes em diálogo com Leonardo da Vinci, numa tradição de representação, por via do discurso da arte, de todo um conjunto de saberes extremamente importantes na cultura ocidental. Diferentes da ontologia, seu estatuto é semiótico, e diz respeito ao modo como o objeto é percebido e partilhado socialmente, fazendo parte da cultura, a qual definiremos, de maneira próxima a Geertz (1973, pp. 4351), não como um conjunto de elementos posteriores à formação do homem enquanto espécie, mas como parte fundamental de sua evolução e constituição - abordagem que dialoga com a perspectiva semiótica do Groupe $\mu$ (2015, passim), na medida em que o fazer sentido e sua cristalização são associados a uma necessidade da espécie em se manter e prosperar.

O saber ontológico é, evidentemente, um fator relevante ao processo de significação, afinal seria absurdo desqualificar toda a produção científica em torno dos alimentos como desprovida de sentido; o que buscamos demonstrar aqui é o fato de que esse modo de enquadrar o objeto é um dentre vários que circulam e coexistem, muitas vezes antagonicamente, mas sempre em constante tensão - a perspectiva semiótica, tal como a definimos aqui, acolhe a pluralidade e o dissenso, admitindo que um mesmo objeto tem o potencial de ser múltiplo na medida em que seu ser é sempre relativo a um sujeito capaz de percebê-lo a partir de um local determinado por condições as mais diversas. Em suma, a ontologia é uma dentre várias possibilidades de alongamento ${ }^{16}$ semiótico, servindo a determinados fins e não a outros.

Por outro lado, isso não significa que qualquer tipo de interpretação possa ser derivada de um objeto, uma vez que a materialidade, como vimos, é também uma das variáveis do processo. Retomando nosso exemplo, pão e vinho são, na mitologia católica, o corpo e o sangue da divindade, e a relação entre corpo e pão, bem como a de sangue e vinho, é claramente dependente dos aspectos sólido e líquido,

\footnotetext{
${ }^{16}$ Para o Groupe $\mu$ (2015, passim), a semiose é constituída já na percepção/estruturação mais simples do mundo ao nosso redor; colocar um membro em água fervente e retirá-lo por causa da dor é, nessa perspectiva, produção de sentido, uma vez que esse movimento depende de um input e um output de informações (táteis, no caso) que são contrastadas com um referencial qualquer que seja - no caso, nosso conhecimento biológico de uma temperatura segura. Essas categorizações iniciais mais básicas podem, segundo o Groupe $\mu$, ser alongadas, constituindo-se como sistemas semióticos cristalizados e partilhados socialmente de diversas formas. Em nosso exemplo, um alongamento seria o dito popular "gato escaldado tem medo de água fria".
} 
respectivamente; seria difícil imaginar o pão como sangue. Isso diz respeito a um princípio de permanência, associado pelo Groupe $\mu$ (2015, passim) a uma perspectiva holística de percepção: um objeto é apreendido sinestesicamente, e algo de suas características se conserva mesmo após os sucessivos recortes e alongamentos semióticos responsáveis por sua cristalização em signos, seus empregos discursivos etc.

Uma teoria de sentido precisa abarcar toda essa variedade de leituras, ao mesmo tempo em que lida com as tensões e conflitos entre elas: semioticamente, uma hóstia é, ao mesmo tempo, corpo e carboidrato, que são apenas duas dentre outras perspectivas e que concorrem entre si por supremacia em contextos discursivos distintos, tentando (in)validar(-se) e sobrepor-se constantemente umas às outras. Trata-se de uma abordagem teórica que busca incluir o dissenso em seus fundamentos, encarando o consenso como um artifício discursivo que visa mascarar a dissonância de múltiplas vozes, criando zonas mais densas a partir dos alongamentos semióticos mais interessantes para este ou aquele projeto (ideológico, social, político etc.).

O breve exemplo da questão culinária pode ser complementado por um mais próximo do âmbito dessa tese: o caso do futebol. Sendo um dos esportes mais populares do mundo e movimentando somas exorbitantes de dinheiro, o estatuto semiótico do futebol dificilmente poderia ser reduzido a ou totalmente desvinculado de suas regras abstratas; com efeito, o que se nota é a sobreposição de camadas de sentido que conflitam umas com as outras.

Em primeiro lugar, poderíamos discutir sua condição de esporte nacional brasileiro, o qual direciona as escolhas de diversas pessoas em diferentes graus: desde a organização de uma agenda social em torno da "pelada" - que junto com o "cafezinho" é uma instituição brasileira - até o desejo de crianças e adolescentes em moldar seus corpos para jogar melhor, na esperança de conseguir uma colocação em algum time - a ascensão social por meio do esporte é, em nossa sociedade, da ordem do senso comum; seja como for a relação pessoal de cada um com o futebol, brasileiros em geral mantêm uma com o esporte, mesmo que em um esforço ativo para ignorar o barulho dos rojões às quartas e domingos, a seção dos telejornais, pular determinados canais de TV cuja programação é quase que inteiramente a ele voltada, ou simplesmente não prestar atenção aos acessórios de vestuário os mais diversos que invadem nosso campo de visão. 
A questão do fanatismo pode ser relacionada a essa superexposição do esporte e das figuras a ele ligadas em nossa cultura, não sendo incomum o surto de conflitos, muitas vezes ligados a agressões físicas, derivados do futebol, sobretudo a discussões sobre times; além disso, há diversos casos fatais derivados de brigas ou que envolvem comportamento de risco. ${ }^{17}$ Menos extremas são alterações corporais (como tatuagens) ou mudança de corte de cabelo para se assemelhar a jogadores, mas demonstram de modo bastante parecido a força desse tipo de alongamento semiótico em nossa sociedade.

Outro aspecto igualmente marcante é a adaptabilidade do conjunto de regras, ocupando desde campos construídos em estádios até a demarcação dos limites com chinelos ou outros objetos cotidianos em ruas; joga-se futebol em praticamente qualquer lugar, a qualquer horário e sob condições climáticas e materiais diversas. Nas modalidades profissionais, há investimento considerável em equipamentos e desenvolvimento de tecnologias com o intuito de melhorar as condições de jogo e garantir que as regras sejam obedecidas; no entanto, nem tudo é aprovado pelos órgãos oficiais, cujo objetivo é manter a integridade do esporte ${ }^{18}$, e há uma parcela de avanços que fica restrita a uso por emissoras de TV para análise de lances e jogadas duvidosas.

Por fim, o futebol também conhece popularidade no campo dos jogos digitais, que conta com duas franquias de enorme sucesso na atualidade (com títulos lançados anualmente), FIFA (EA Sports) e PES: Pro Evolution Soccer (Konami), cuja fidelidade ao esporte original é exaltada: times famosos são inclusos (Real Madrid, Barcelona, Paris Saint-Germain etc.), e os modelos tridimensionais dos jogadores profissionais e dos estádios são baseados em suas contrapartes reais. Há também alguns títulos esparsos, como Super Mario Strikers (Next Level Games/Nintendo, 2005) e Mario Strikers Charged (Next Level Games/Nintendo, 2005), que modificam diversas regras do esporte original para adaptá-lo ao universo ficcional dos mascotes da Nintendo - é possível fazer dribles

\footnotetext{
${ }^{17}$ A busca no Google pelo sintagma "Torcedor morre", colocado entre aspas para filtrar apenas resultados que o contém exatamente nesse formado, gera mais de 49 mil resultados (consulta feita em Julho de 2019).

${ }^{18}$ http://gizmodo.uol.com.br/fifa-admite-que-tecnologia-deve-entrar-no-futebol-mas-nao-completamente/ http://globoesporte.globo.com/futebol/noticia/2012/07/fifa-aprova-o-uso-de-bolas-com-chip-paravalidacao-de-gols.html (Acesso em Julho de 2019)
} 
e movimentos especiais (que envolvem explosões, cascos de tartaruga sendo arremessados) e usar itens insólitos (cascas de banana, cogumelos). ${ }^{19}$

Assim como no caso do pão e do vinho, considerar o futebol apenas como um conjunto estrutural não dá conta da variedade de leituras e usos sociais que são diretamente ligados ao esporte; em contrapartida, ignorar que se trata de um conjunto de regras não explica o esforço empreendido tanto por indivíduos quanto por instituições para a manutenção da identidade do futebol, perpassando até mesmo os usos considerados desviantes e cômicos da série Mario Strikers - mesmo com uma proposta de modificação, ainda há a preocupação com o fato de que essa variante digital precisa ser reconhecida como futebol.

Há, portanto, múltiplos sistemas semióticos envolvidos na produção de sentido, sejam de qual objeto forem, e a escolha por isolar um ou mais deles não pode ignorar tal multiplicidade e advogar pela redução do objeto a um desses aspectos, identificando-o como único ou hierarquicamente superior a todos os demais, responsável pela produção de seu sentido verdadeiro. Se isolar as partes de um complexo é necessário para que o fazer científico-analítico renda frutos, o discurso ontológico - tal qual o definimos aqui tem suas raízes em uma concepção bem específica desse fazer, que será discutida no próximo tópico.

\section{O ponto zero}

Para iniciarmos a discussão da primazia da ontologia é preciso, antes, tocar em outro tema, o da divisão colonial do mundo. Segundo Castro-Gomez e Grosfoguel (2007), o conceito de colonialidade é dependente de diversos fatores - como a divisão do trabalho e as fronteiras políticas que determinam quem pode ou não circular, e como isso se dá -, pressupondo sempre um estado de desigualdade; esta se dá por uma visão hierárquica, que nega a coexistência de diferentes modos de pensar:

A negação da simultaneidade epistêmica, isto é, a coexistência no tempo e no espaço de diferentes formas de produzir conhecimentos cria um duplo mecanismo ideológico. Em primeiro lugar, ao não compartilhar o mesmo tempo

\footnotetext{
${ }^{19} \mathrm{O}$ vídeo a seguir contém uma partida de Mario Strikers Charged:

https://www.youtube.com/watch?v=Bkul25FnqJE (Acesso em Julho de 2019)
} 
histórico e viver em diferentes espaços geográficos, o destino de cada região é concebido como não relacionado a nenhum outro. Em segundo lugar, Europa/Euro-América do Norte são pensadas como vivendo uma etapa de desenvolvimento (cognitivo, tecnológico e social) mais "avançada" que o resto do mundo, e a partir disso surge a ideia de superioridade da forma de vida ocidental sobre todas as demais. Assim, a Europa é o modelo a se imitar e a meta desenvolvimentista era (e continua sendo) "alcançá-los". Isso se expressa nas dicotomias civilização/barbárie, desenvolvido/subdesenvolvido, ocidental/nãoocidental, que marcaram categoricamente boa parte das ciência sociais modernas.

La negación de la simultaneidad epistémica, esto es, la coexistencia en el tiempo y el espacio de diferentes formas de producir conocimientos crea un doble mecanismo ideológico. En primer lugar, al no compartir el mismo tiempo histórico y vivir en diferentes espacios geográficos, el destino de cada región es concebido como no relacionado con ningún otro. En segundo lugar, Europa/Euro-norteamérica son pensadas como viviendo una etapa de desarrollo (cognitivo, tecnológico y social) más "avanzada" que el resto del mundo, con lo cual surge la idea de superioridad de la forma de vida occidental sobre todas las demás. Así, Europa es el modelo a imitar y la meta desarrollista era (y sigue siendo) "alcanzarlos". Esto se expresa las dicotomías civilización/barbarie, desarrollado/subdesarrollado, occidental/no-occidental, que marcaron categorialmente a buena parte de las ciencias sociales modernas. (p. 15)

Ao determinar que determinados modos de ser e fazer sentido do mundo são atrasados, o ponto de referência se coloca fora da história, uma vez que, se desigualdade epistêmica de fato há, ela não é relacionada com o desenvolvimento de relações coloniais, o estabelecimento artificial de fronteiras, a invenção do chamado "terceiro mundo" e, inclusive, o estabelecimento do conhecimento acadêmico como a única forma de saber possível; em suma, o estado atual do mundo é caracterizado como acidental e a episteme ocidental eurocêntrica, como neutra.

Segundo os autores, essa hierarquia só é possível a partir de uma abstração extrema de si mesmo, conceito de Castro-Gómez denominado "hybris do ponto-zero" (cf. GROSFOGUEL, 2007, p. 64; CASTRO-GÓMEZ, 2007, p. 79): ao desconsiderar a história em que se insere e as limitações de si próprio enquanto sujeito localizado na 
história, o "eu" se alça e se considera capaz de enxergar a totalidade livre de viéses; torna-se universal, em oposição aos demais, presos em sua ignorância local, atrasada e, portanto não concomitante. Essa abstração é relacionada a uma derivação do método cartesiano. Segundo Grosfoguel (2007, p. 63-4), Descartes, contrariando a visão teocêntrica dominante em sua época,

colocou o "eu" onde antes estava Deus como fundamento do conhecimento. Todos os atributos do Deus cristão ficaram localizados agora no "sujeito", o "eu". Para poder reclamar a possibilidade de um conhecimento mais além do tempo e do espaço, a partir dos olhos de Deus, era fundamental desvincular o sujeito de todo corpo e território; por assim dizer, esvaziar o sujeito de toda determinação espacial ou temporal. Portanto, o dualismo é um eixo fundamental e constitutivo do cartesianismo. O dualismo é o que permite situar o sujeito em um "não-lugar" e em um "não-tempo", o qual o habilita a fazer uma reivindicação mais além de todo limite espaço-temporal na cartografia de poder mundial. Para poder situar o sujeito como fundamento de todo conhecimento, o monólogo interno do sujeito, sem nenhuma relação dialógica com outros seres humanos, permite-lhe reivindicar o acesso à verdade de forma sui generis, isto é, como auto-gerado, ilhado de relações sociais com outros seres humanos. O mito da auto-produção da verdade por parte do sujeito ilhado é parte constitutiva do mito da modernidade de uma Europa auto-gerada, ilhada, que se desenvolve por si mesma sem dependência de ninguém no mundo. Então, da mesma maneira que o dualismo, o solipsismo é constitutivo da filosofia cartesiana. Sem solipsismo não há mito de um sujeito com racionalidade universal que se confirma a si mesmo como tal.

puso al 'yo' donde antes estaba Dios como fundamento del conocimiento. Todos los atributos del Dios cristiano quedaron localizados ahora en el 'sujeto', el 'yo'. Para poder reclamar la posibilidad de un conocimiento más allá del tiempo y el espacio, desde el ojo de Dios, era fundamental desvincular al sujeto de todo cuerpo y territorio; es decir, vaciar al sujeto de toda determinación espacial o temporal. De ahí que el dualismo sea un eje fundamental constitutivo del cartesianismo. El dualismo es lo que permite situar al sujeto en un 'no-lugar' y en un 'no-tiempo', lo cual le habilita para hacer un reclamo más allá de todo límite espacio-temporal en la cartografía de poder mundial. Para poder situar al sujeto como fundamento de todo conocimiento, el monólogo interno del sujeto, sin ninguna relación dialógica con otros seres humanos, le permite hacer un 
reclamo de acceso a la verdad de forma sui generis, es decir, como autogenerado, insulado de relaciones sociales con otros seres humanos. El mito de la auto-producción de la verdad por parte del sujeto aislado, es parte constitutiva del mito de la modernidad de una Europa autogenerada, insulada, que se desarrolla por sí misma sin dependencia de nadie en el mundo. Entonces, al igual que el dualismo, el solipsismo es constitutivo de la filosofía cartesiana. Sin solipsismo no hay mito de un sujeto con racionalidad universal que se confirma a sí mismo como tal.

Essa leitura está de acordo com o exposto pelo próprio Descartes em seu Discurso do Método ${ }^{20}$, em que descreve seu longo processo de busca pela Verdade por meio de um modelo de pensar a si mesmo como dotado de uma faculdade inalienável de pensamento (cuja origem remontaria a Deus), separada de qualquer materialidade - a oposição teocêntrica apontada por Grosfoguel (2007) diz respeito à mudança de foco: o sujeito possui, em si mesmo, essa faculdade, a Mente.

O universalismo abstrato cartesiano é assim caracterizado por Grosfoguel (2007, p. 65) em dois sentidos: um referente ao enunciado - isto é, relativo à abstração de estruturas a partir de objetos - e outro relacionado à enunciação - referente à postura do "eu" em se considerar capaz de se apropriar da totalidade sem viéses.

O primeiro tipo de universalismo abstrato (o dos enunciados) é possível somente se se pressupõe o segundo (o do sujeito de enunciação). O primeiro sentido de universalismo abstrato, o do universalismo baseado em um conhecimento com pretensões de eternidade espaço-temporal, de enunciados que se "abstraem" de toda espacialidade e temporalidade, foi questionado dentro da própria cosmologia e filosofia ocidental. mas o segundo sentido de universalismo abstrato, no sentido epistêmico do sujeito de enunciação sem rosto nem localização espaço-temporal, o da ego-política do conhecimento, continuou, até nossos dias, com o ponto zero das ciências ocidentais, ainda entre os críticos do próprio René Descartes, e é um dos legados mais perniciosos do cartesianismo.

El primer tipo de universalismo abstracto (el de los enunciados) es posible solamente si se asume el segundo (el del sujeto de enunciación). El primer sentido de universalismo abstracto, el del universalismo basado en un

${ }^{20}$ Discurso do Método. Tradução de Paulo Neves. Porto Alegre: L\&PM, 2011. 
conocimiento con pretensiones de eternidad espacio-temporal, de enunciados que se 'abstraen' de toda espacialidad y temporalidad, ha sido cuestionado dentro de la propia cosmología y filosofía occidental. Pero el segundo sentido de universalismo abstracto, en el sentido epistémico del sujeto de enunciación sin rostro ni localización espaciotemporal, el de la ego-política del conocimiento, ha continuado, hasta nuestros días, con el punto cero de las ciencias occidentales, aun entre los críticos del propio René Descartes, y es uno de los legados más perniciosos del cartesianismo. (Idem)

Dentre os filósofos que tentam resolver alguns dilemas cartesianos, Grosfoguel cita Kant, que em sua Crítica da Razão Pura ${ }^{21}$ define espaço e tempo como duas intuições a priori, isto é, não derivadas empiricamente de objetos - os quais, para ele, jamais podem ser conhecidos em si, mas sempre enquanto fenômenos que afetam a Mente de alguma maneira; nesse sentido, espaço e tempo não são propriedades dos fenômenos, mas condição básica de sua apreensão, sendo, portanto, um dos pilares da universalidade subjetiva que Kant atribui a todos os homens.

No entanto, segundo Grosfoguel, Kant restringe seu conceito de "Homem": "para Kant, a razão transcendental é masculina, branca e europeia (Kant, 2004b). Os homens africanos, asiáticos, indígenas, sub-europeus (espanhóis, italianos e portugueses) e todas as mulheres (incluindo as europeias) não têm capacidade de 'razão'"22 (Idem, p. 66) A partir disso, o autor afirma o seguinte:

Em Kant se mantém o dualismo mente-corpo e o solipsismo cartesiano, mas revisados e atualizados. Kant questiona o primeiro tipo de universalismo cartesiano (o dos enunciados), isto é, a possibilidade de um conhecimento eterno da coisa em si para além de toda categoria de espaço-temporalidade. Mas mantém e aprofunda o segundo tipo de universalismo abstrato cartesiano, o epistemológico, quando ao fazer explícito o que em Descartes era implícito, apenas o homem europeu tem acesso a produzir conhecimentos universais, isto é, quando no nível de sujeito de enunciação, um particular define para todos no

\footnotetext{
${ }^{21}$ Crítica da Razão Pura. Coleção Os Pensadores. Tradução de Valerio Rohden e Udo Baldur Moosburger. São Paulo: Nova Cultural, 1999.

22 "para Kant la razón trascendental es masculina, blanca y europea (Kant, 2004b). Los hombres africanos, asiáticos, indígenas, sureuropeos (españoles, italianos y portugueses) y todas las mujeres (incluidas las europeas) no tienen capacidad de 'razón'."
} 
planeta o que é o universal. Portanto, quando Kant propõe seu cosmopolitanismo trata-se de um provincialismo europeu, camuflado de cosmopolitanismo universalista e vendido ao resto do mundo como desenho global/imperial.

En Kant se mantiene el dualismo mente-cuerpo y el solipsismo cartesiano, pero reformados y actualizados. Kant cuestiona el primer tipo de universalismo abstracto cartesiano (el de los enunciados), es decir, la posibilidad de un conocimiento eterno de la cosa en sí, más allá de toda categoría de espacio-temporalidad. Pero mantiene y profundiza el segundo tipo de universalismo abstracto cartesiano, el epistemológico, donde al hacer explícito lo que en Descartes era implícito, solamente el hombre europeo tiene acceso a producir conocimientos universales, es decir, donde a nivel del sujeto de enunciación, un particular define para todos en el planeta qué es lo universal. De ahí que cuando Kant propone su cosmopolitanismo se trata de un provincialismo europeo, camuflado de cosmopolitanismo universalista y vendido al resto del mundo como diseño global/imperial. (lbidem)

A associação entre colonialidade e filosofia é feita a partir dos deslocamentos de poder referentes à época:

Enrique Dussel (1994) nos lembra, em diversas ocasiões, que o ego cogito cartesiano do "eu penso, logo existo" é precedido por 150 anos pelo ego conquirus imperial do "eu conquisto, logo existo". Lembremos que Descartes escrevia sua filosofia de Amsterdam, justo no momento em que a Holanda passa a ser o centro do sistema-mundo em meados do século XVII. O que Enrique Dussel nos diz com isso é que a condição da possibilidade política, econômica, cultural e social para que um sujeito assuma a arrogância de falar como se fosse os olhos de Deus é o sujeito cuja localização geopolítica está determinada por sua existência como colonizador/conquistador, isto é, como Ser imperial.

Enrique Dussel (1994) nos ha recordado, en múltiples ocasiones, que el ego cogito cartesiano del 'yo pienso, luego soy' está precedido por 150 años del ego conquirus imperial del 'yo conquisto, luego soy'. Recordemos que Descartes escribía su filosofía desde Amsterdam, justo en el momento en que Holanda pasa a ser el centro del sistema-mundo a mediados del siglo XVII. Lo que Enrique Dussel nos dice con esto es que 
la condición de posibilidad política, económica, cultural y social para que un sujeto asuma la arrogancia de hablar como si fuera el ojo de Dios, es el sujeto cuya localización geopolítica está determinada por su existencia como colonizador/conquistador, es decir, como Ser imperial. (Idem, p. 64)

A partir dessa associação, Grosfoguel (Idem, p. 65) aponta que, à época de Kant, o cenário se altera e a Holanda perde poder enquanto metrópole. Sendo assim, é razoável, em nossa perspectiva associar as mudanças epistemológicas com o jogo de poder colonial.

Não se trata, evidentemente, de afirmar que Descartes ou Kant participaram efetivamente da conquista colonial ou que esperaram pacientemente por mudanças na balança de poder para publicar suas obras, e sim de localizar historicamente uma espécie de cenário propício, por assim dizer, para que alguém possa dizer o que dizem e se sinta confortável ao fazê-lo; nessa esteira, o termo "arrogância" utilizado por Grosfoguel nos parece inadequado, uma vez que a questão geopolítica nos fornece dados para explicar como esse tipo de pensamento surge, o contexto do qual se alimenta. Mais adequado, o termo "hybris" é recuperado por Castro-Gómez (2007, p. 83), remetendo à tragédia clássica, para caracterizar o excesso dessa postura enunciativa que coloca o "eu" acima dos demais mortais, igualando-o ao divino que é capaz de tudo ver; a ideia de excesso como algo que ao mesmo tempo possibilita um ponto de vista e impede que outros sejam considerados é mais próxima de nossa perspectiva: não se trata de algo conscientemente calculado, mas de uma conjunção complexa de eventos históricos que não nos permite apontar nem Kant nem Descartes como vilões.

Seja como for, o que nos interessa imediatamente é que a ideia de universalidade em seu uso mais comum requer esse movimento de abstração e neutralização do "eu" que fala, caracterizando os demais pontos de vista como desvios, viéses ou erros, e que esse movimento é possível apenas na medida em que há um contexto geopolítico que o torna possível como horizonte epistemológico. Relacionando mais diretamente com o propósito desta tese, essa associação nos interessa na medida em que tanto o cartesianismo quanto o kantismo perduram no discurso acadêmico e cientificista - a própria ideia de método científico como algo mais adequado à produção de conhecimento que o senso comum, e o princípio de que proposições lógicas podem ser falseadas, mas não verificadas enquanto essência absoluta de objetos estão associadas de maneira muito forte, respectivamente, às obras de Descartes e Kant aqui citadas. 
No que concerne à questão colonial, o local de origem dos autores de ludologia trabalhados neste capítulo adquire importância: Bogost fala dos Estados Unidos, enquanto Sicart conduz sua pesquisa na Europa, dois dos três grandes produtores de tecnologia - sendo o terceiro o chamado sudeste asiático, ali incluído o Japão. É esperado que lidem com o tema a partir de uma perspectiva que ignora nuanças relativas às diferenças socioeconômicas e epistemológicas entre os chamados primeiro e terceiro mundos, uma vez que, como visto, a formação desse conceito alça aquele à posição de neutralidade ao mesmo tempo em que rebaixa este e o apaga enquanto lugar epistêmico; dito de outro modo, não se considera a atividade produzida fora dos centros como um tipo válido de conhecimento, pois o ponto de vista que confere a uma semiose ao estatuto de ontologia absoluta só o pode fazer enquanto nega sentidos concorrentes.

Sendo assim, a ideia de Bogost (2006; 2007) em atribuir o sentido do jogo unicamente à estrutura formal que ele, enquanto pesquisador e designer do centro, é capaz de abstrair (ou, em nossa perspectiva, projetar); e o ponto de vista de Sicart (2014) que ignora completamente o contexto em que as apropriações de espaço lúdicas se dão, bem como o corpo que efetivamente se apropria - incluindo aí as eventuais impossibilidades de se apropriar -, são exemplos recentes do movimento epistemológico que Grosfoguel e Castro-Gómez (2007) associam à permanência do modelo cartesiano/kantiano de pensamento, ao qual voltaremos no próximo capítulo a partir do trabalho de Alcoff (2007).

O que nos interessa mais imediatamente é ressaltar a importância de uma perspectiva semiótica, tal qual a definimos aqui, que abarque as tensões e diferenças entre os diferentes sentidos que dialogam, se sobrepõem e/ou se chocam constantemente. O trabalho do Groupe $\mu$ (2015) dá um passo importante nessa direção ao considerar tanto a semiose individual quanto a coletiva, e ao colocar como centro do processo o corpo biológico e a percepção a partir dele; no entanto, há ainda lacunas a se preencher. O postulado semiótico desse trabalho é, em si, universalista, embora de outra ordem, uma vez que se baseia nos avanços da biologia e da neurociência para aproximar todos os seres humanos enquanto espécie, mas os diferencia culturalmente e inclui a diversidade no modelo em si; apesar disso, o fundamento teórico no qual essa perspectiva se baseia é bastante geral e não localiza as diferenças, tal como o fazem Grosfoguel e Castro-Gómez (2007) - e também Ahmed (2007) e Alcoff (2007), que serão utilizadas no próximo capítulo. Isso não representa, evidentemente, um problema que 
invalide o trabalho do Groupe $\mu$ (2015), uma vez que seu objetivo é estabelecer as bases de uma semiótica cognitiva; todavia, isso não significa que tal modelo, para ser eficiente em situações concretas de análise, não precise ser revisado ou complementado com esse tipo de estudo.

Com efeito, uma vez que o corpo é encarnado - isto é, composto de células e não meramente uma instância discursiva - e localizado na história, faz-se mister, ao mobilizar esse aparato teórico, trazer também estudos de outras áreas a que não se atribui o rótulo de "semiótica", mas que refletem sobre a constituição histórica, cultural e social de corpos, e o modo como estes agem no e sobre o espaço; dentre eles, já mencionamos os decoloniais, mas incluiremos também trabalhos advindos da teoria queer, do feminismo, dos estudos sobre raça, etnia e nacionalidade. Nosso objetivo será demonstrar como essas problemáticas - a saber, gênero, sexualidade, raça e posição na hierarquia (pós-)colonial - são variáveis incontornáveis ao se estudar semioticamente o jogo digital, uma vez que a questão tecnológica é indissociável da econômica, que determina o acesso aos produtos, e esta é, de modo bastante explícito, ligadas aos aspectos do corpo supracitados.

Dizendo de outro modo, nossa proposta é de revisar o modelo abstracionista de análise por meio de uma perspectiva que chamaremos semiótica intercultural, a qual se propõe a trazer para o campo de análise as variáveis comumente deixadas de lado pelos pontos de vista universalistas; não se trata, no entanto, de invalidar o conhecimento deles derivado - a perspectiva eurocêntrica é também uma variável importante semioticamente na medida em que direciona práticas semióticas, formas de viver e transformar o mundo -, mas de problematizá-lo em relação aos outros. Chamamos de intercultural e não de multicultural, pois não há interesse em analisar cada aspecto separadamente e em si mesmo, dando a cada um uma possibilidade de existência isolada e coerente em si mesma; nosso interesse é justamente mostrar as intersecções, tensões, conflitos - o sentido, sob nosso ponto de vista, é o que resta desse conflito, um rescaldo desse choque de elementos tão diversos.

Estando explicitado o ponto de partida desta tese, passaremos agora à discussão do conceito de espaço e de sua configuração semiótica em relação ao corpo, a ser exposta no próximo capítulo, centrado, como dissemos acima, nos trabalhos de 
fenomenologia queer de Ahmed (2007) e na abordagem de conflitos raciais e étnicos feita por Alcoff (2007). 


\section{Capítulo 2}

\section{A configuração semiótica do espaço}

No capítulo precedente nos dedicamos à exposição sumária de algumas dentre as principais questões e linhas de estudo encontradas atualmente no campo dos jogos, reservando espaço aos trabalhos pertencentes ao campo da ludologia, disciplina de formação recente e cujo foco reside no estudo do jogo em si mesmo, sua definição e suas especificidades; em seguida, apontamos como essas investigações têm um caráter fortemente ontológico e que conflitam com uma perspectiva semiótica - muito embora os autores da ludologia valham-se de estudos semióticos para embasar suas posturas.

Como demonstramos, o percurso e o método utilizados ancoram-se largamente no que Grosfoguel e Castro-Gómez (2007) chamam de cartesianismo - muito embora não haja menção direta à obra de Descartes em boa parte dos trabalhos aqui citados. Em resposta a esse viés, nos dedicaremos aqui à apresentação de uma proposta alternativa, centrada no conceito de espaço, que foi utilizado até o momento sem uma definição precisa fora do âmbito da ludologia. O capítulo será dividido em três seções, com dois tópicos cada, abordando três linhas gerais: 1) o espaço como objeto semiótico; 2) a construção identitária como fundamento do espaço; e 3) o motivo pelo qual consideraremos jogos, inclusive os digitais, como uma maneira de apropriação de espaços.

Começaremos com uma introdução geral ao conceito, partindo do senso comum e da ludologia, e seguindo pelo viés da semiótica. Nossa abordagem será fundamentalmente materialista e histórica - não no sentido frequentemente dado a essas palavras, mas no fato de que nos ancoramos no modo como sujeitos, localizados no tempo e no espaço, percebem um mundo e nele atuam, conferindo-lhe sentido ao fazêlo. Em outros termos, partiremos do pressuposto de que sujeitos são encarnados, dotados de aparatos sensoriais (olhos, ouvidos, nariz etc.); de identidades (de gênero, raça, sexualidade); e que se organizam social e economicamente por meio da na interação complexa de todos os atributos de seus corpos, cuja composição é ao mesmo tempo natural (biológica) e cultural (construída semioticamente). A partir disso, discutiremos a questão do espaço digital, muitas vezes oposto ao analógico sem um 
embasamento plausível; demonstraremos que essa distinção é artificial e pode ser relativizada com base nos avanços da semiótica e da neurociência.

Estabelecidas as linhas gerais, partiremos para a sua constituição identitária. Essa seção contará com uma longa exposição dos trabalhos de Sara Ahmed (2006) e Linda Alcoff (2006), cujo foco recai sobre a relação inerente entre as identidades dos sujeitos e o modo como espaços são por eles ocupados; as autoras não só apontam a impossibilidade de se despir do próprio corpo e história, mas também demonstram como o espaço em si é moldado a partir desses elementos que a civilização ocidental sobretudo no campo da ciência - tenta apagar. Trata-se, evidentemente, de um ponto de vista bastante diferente daquele utilizado em ludologia, cujo objetivo era, reiteramos, estabelecer modelos de análise focados em uma ontologia objetiva e neutra - uma estrutura universal, por assim dizer - do jogo.

As ideias de Ahmed e Alcoff serão comparadas a conceitos importantes da semiótica - com destaque para os trabalhos de Greimas (2014), Fontanille (2015) e do Groupe $\mu$ (2015) - e a alguns casos de opressão relacionados a jogos. O caráter dialógico da disciplina - largamente apontado tanto por Greimas quanto por Fontanille em diversos pontos de suas obras - será aqui evidenciado e aproveitado ao máximo uma vez que os conceitos apresentados não serão mobilizados isoladamente, mas somente na medida em que são capazes de estabelecer pontes entre as discussões aqui citadas; os instrumentos cunhados pela disciplina semiótica serão, portanto, utilitários e não constituirão um fim em si mesmos. É importante frisar que o uso do termo "semiótica" no título deste capítulo diz menos a respeito de uma metalinguagem, metodologia ou filiação teórica específicas e mais acerca de uma mudança de perspectiva em relação ao tratamento corrente do tema, marcando uma postura transdisciplinar em relação ao objeto: não se trata de algo que existe por si, isolado das demais linguagens, mas algo constitutivo do constante fazer sentido dos sujeitos históricos inseridos num mundo cuja apreensão é sempre mediada.

Finalizaremos com a discussão do espaço lúdico a partir dos conceitos apresentados nas duas primeiras seções deste capítulo. A exposição será feita, em primeiro lugar, por meio de análises de jogos analógicos e esportes, para depois concentrarmo-nos na especificidade digital, analisada em maior detalhe na Segunda Parte. Nosso objetivo é demonstrar a necessidade de revisar diversos dos conceitos apresentados anteriormente por meio de uma perspectiva intercultural, caso os estudos 
de jogo desejem dar conta da complexidade do objeto em um mundo marcado por diferenças.

Reiteramos que nosso objetivo neste texto não é descartar, mas relativizar o conhecimento acumulado tanto pela antropologia quanto pela ludologia, e contrastá-lo com outros saberes, principalmente os de perspectiva pós-colonial, uma vez que que esse viés: 1) leva em conta a desigualdade constitutiva de um mundo marcado por uma história de colonialidade; e 2) busca localizar historicamente seus argumentos, i.e., relacioná-los às condições socioculturais do sujeito enunciador na ocasião de enunciação. Queremos, em suma, não apenas apontar a impossibilidade de eliminar os viéses - constitutivos de qualquer abordagem -, mas de valorizá-los e aproveitá-los no âmbito da ludologia para ampliar seu alcance e pertinência.

\section{Considerações preliminares sobre o conceito de espaço}

Antes de iniciar a via da semiótica, vejamos sumariamente algumas noções de espaço relevantes para os autores previamente citados: no senso comum e dicionarizado, espaço é sinônimo de extensão, limitada ou não, cuja principal característica é a capacidade de conter $^{23}$; no sentido dado por Huizinga (1949) e Caillois (2000), o jogo, por meio de uma delimitação espacial, é algo que se separa do mundo, protegido das interferências deste. Sicart (2014, passim), por sua vez, caracteriza o jogo como apropriação de espaço de modo muitas vezes transgressor e com caráter estético; trata-se do cruzamento de fronteiras e da produção de conteúdo. Há, portanto, uma constante semântica que aproxima o senso comum do uso do termo no campo de estudo do jogo: o estabelecimento de fronteiras, de limiares, evidenciando que espaços são construções. Aprofundemos, agora, essa discussão.

\section{Abordagem semiótica}

Semioticamente, espaço recebe definições diferentes de acordo com a vertente ou nível de análise focado. De acordo com Greimas e Courtés (2012), o denominador comum do conceito de espaço é o fato de "ser considerado um objeto construído (que

\footnotetext{
${ }^{23}$ HOUAISS, A. Dicionário Houaiss da Lingua Portuguesa. Rio de Janeiro: Objetiva, 2009.
} 
comporta elementos descontínuos), a partir da extensão, esta encarada como uma grandeza plena, sem solução de continuidade" (p. 177, realces no original); enquanto construto, o espaço não pode prescindir do sujeito, "considerado como [seu] produtor e como consumidor" (p. 178), sobretudo no que diz respeito ao seu corpo, aos sentidos abrindo aqui o caminho para a percepção e identificando-se com o mundo natural ${ }^{24}$, da qual o espaço é uma construção explícita. O espaço é, portanto, lugar de uma interação complexa entre "natureza" e "cultura" (sendo aquela delimitada por esta ${ }^{25}$ ), configurandose como um objeto complexo, dotado de planos de expressão e de conteúdo, e sobre o qual as ações de sujeitos se desenrolam - transformando-o ao mesmo tempo em que se transformam. A constituição do plano de expressão do espaço passa por diversos níveis, indo desde signos mínimos até formas de vida - i.e., configurações multifacetadas de persistência da vida de sujeitos por meio da coordenação de estratégias, práticas e textos (cf. FONTANILLE, 2015, passim).

No nível tensivo, relacionado ao ato perceptivo que separa sujeito e objeto, o espaço (junto com tempo) pertence ao conjunto de subvalências ${ }^{26}$ da extensidade relativas ao racionalizar -, opostas às da intensidade (ritmo e andamento) - relacionadas ao sentir; as valências e subvalências funcionam como um gradiente regulador das duas partes da percepção humana. Sendo as bases da significação constituídas a partir da tensão entre sentir e racionalizar (os dois polos valenciais), podemos, então, falar de espaço enquanto fundamento da percepção humana - a capacidade de (de)limitar aquilo em que estamos contidos.

Há, portanto, uma dupla orientação relativa ao espaço em semiótica: sua delimitação intrínseca é, ao mesmo tempo, fruto da percepção e elemento constitutivo dela. Tal constatação está de acordo com a proposta do Groupe $\mu(2015$, passim), que considera impossível a dissociação entre os dois polos da produção de sentido (semiose), ana- e cata-semiose, conceitos que podemos simplificar didaticamente por meio dos termos correntes input e output: o primeiro corresponde à apreensão do

\footnotetext{
${ }^{24}$ Para a semiótica, o conceito de "mundo natural" trata não da ontologia física e biológica do mundo, mas do seu parecer; da camada de superfície discursiva, que diz respeito à relação entre sujeito e objeto. "Natural" se deve à anterioridade ao indivíduo que nele "se inscreve desde o nascimento - e nele se integra progressivamente - pela aprendizagem - em um mundo significante feito ao mesmo tempo de 'natureza' e 'cultura'" (GREIMAS E COURTÉS, 2012, p. 324). Para uma discussão mais aprofundada cf. GREIMAS, 1970, pp. 49-91.

${ }^{25}$ Cf. GREIMAS E COURTÉS, 1986, pp. 78-79

${ }^{26}$ Valências são os elementos constitutivos das categorias de valores. que, ao serem complexificados narrativa e discursivamente, constituem-se como temas e figuras. Cf. ZILBERBERG E FONTANILLE, 2001, pp. $15-37$.
} 
mundo dado aos sentidos por um aparelho perceptivo previamente disposto não só por suas características biológicas, mas também por limiares culturais/subjetivos (as chamadas grades de leitura); o segundo, em contrapartida, trata da ação engendrada pelo sujeito e que transforma o mundo, seja por uma intervenção direta na materialidade, seja pela comunicação por meio de sistemas semióticos - os quais, por sua vez, são transmitidos e partilhados por diversos sujeitos, constituindo-se como grades de leitura.

Esse processo catassemiótico que transcende o espaço subjetivo e faz com que percepções sejam cristalizadas em grades compartilhadas é característico de semioses longas, em oposição às semioses curtas, próprias de situações de estímulo-resposta imediatos (como o reflexo corporal de desviar de algo, por exemplo). Trata-se de uma aproximação do modelo peirceano de semiose, baseado num percurso interpretativo contínuo e sem fim, em que o resultado de um processo sígnico - i.e., o estabelecimento de uma representação de um objeto por outro por mediação de uma Mente - é incorporado como elemento representante de outro processo sígnico e assim por diante.

No que toca à nossa discussão do conceito de espaço, as noções de limitação e partilha expandem-se para além do senso comum: não só compartilhamos e delimitamos fisicamente o espaço como também o fazemos cognitivamente - o que podemos perceber é 1) enviesado pelo cultural; 2) determinado (em certos aspectos) pelo grupo de que fazemos parte; e 3) pertencente a um processo mais complexo e longo composto pela interação de diversas variáveis. É nesse sentido que o trabalho de Ahmed (2006) pode ser aproximado do de Alcoff (2006) e das perspectivas ludológicas apresentadas ao longo deste texto: espaço é, ao mesmo tempo, vida em conjunto e estruturação enviesada dessa mesma vida; despidos de suas idiossincrasias e determinações culturais, sujeito e espaço, interdefinidos semioticamente, são impossibilitados de existir.

Trabalharemos com o pensamento de Ahmed e Alcoff na próxima seção, de modo menos sumário. Antes disso, introduziremos um tópico para discutir alguns pontos relativos aos espaços digitais, comumente nomeados "virtuais" para diferenciá-los dos "reais" - distinção essa que, no âmbito de nossa tese, perde sentido e operacionalidade. 


\section{O espaço digital ${ }^{27}$}

Parece intuitivo e óbvio que haja uma diferença fundamental entre um ambiente digital e o mundo "real", onde a vida acontece; enquanto o segundo existe de maneira independente do homem - sendo do âmbito da natureza -, o primeiro é intrinsecamente cultural, produto da ação humana e fruto de séculos de desenvolvimentos tecnológicos os mais diversos. Essa diferença está na base de diversas teorizações, dentre as quais poderíamos citar a reflexão acerca das imagens técnicas, opostas às tradicionais devido ao grau de mediação existente entre imagem e mundo real: enquanto estas são desenvolvidas a partir do contato sensorial entre sujeito e mundo, aquelas são geradas por produtos tecnológicos diversos cuja constituição é, já de si, uma abstração imagética - para Flusser (2011, pp. 21-36), a escrita é uma abstração de imagens e a sociedade tecnológica que dela deriva cria produtos variados (câmeras, computadores etc.) capazes de gerar imagens; enquanto o modelo tradicional (analógico) baseia-se em processos físicos e químicos (desgaste de grafite, produtos fotoquímicos etc.), a imagem digital é, em sua essência, um conjunto de dados binários cuja aparência é visual ${ }^{28}$. Trata-se, portanto, de uma distinção que leva em conta o caráter ontológico e material dessas imagens, bem como a quantidade de camadas que separam o referente de seu representante no processo sígnico.

A relação entre a discussão acerca das imagens técnicas e dos ambientes digitais, predominantemente visuais, é evidente e parece bem fundamentada. No entanto, à luz do que foi apontado no item anterior, a diferenciação entre os graus de mediação perde força e pertinência na medida em que a construção do espaço, como vimos, é culturalmente mediada e enviesada pelas grades de leitura; mesmo diante de uma situação analógica, em que um desenhista reproduz um vaso ou paisagem qualquer no papel, elementos como a perspectiva linear já direcionam o olhar e limitam aquilo que pode ser representado imageticamente e como o processo será feito.

Muito embora não possamos enquadrar conceitos como a perspectiva dentro do conceito de "aparelho", é possível considerá-los como ferramentas, tal como definidas pelo Groupe $\mu$ (2015, p. 413-431): alongamentos semióticos compartilhados, seja

\footnotetext{
${ }^{27}$ As ideias apresentadas neste tópico são devidas em grande parte aos diversos debates em sala de aula e apontamentos feitos durante o curso Questões da Imagem II, ministrado pela Prof. ${ }^{a}$ Dr. $^{\text {a }}$ Sílvia Laurentiz no primeiro semestre de 2015 na Escola de Comunicações e Artes da Universidade de São Paulo.

${ }^{28}$ Ver também COUCHOT, 1993
} 
enquanto signos ou objetos utilitários, que concentram modos de analisar e agir sobre o mundo (ana- e cata-semiose, portanto), conservando e direcionando energia cognitiva, e, portanto, mediando a relação entre sujeito e mundo. Toda ferramenta adiciona camadas e "distorce" a percepção - colocamos o verbo entre aspas uma vez que, diante da impossibilidade de captar o mundo sem mediação, termos como "normalidade" e "distorção" perdem relevância nesse contexto. Além disso, mesmo que se desconsidere o caráter ferramental das grades de leitura, a própria interação entre os mais diversos elementos físicos/fisiológicos não pode prescindir de mediação: o olho humano é incapaz de perceber determinadas nuanças e sua fisiologia estabelece zonas perceptivas mais densas - fenômeno denominado barissemia (barysémie, em francês) pelo Groupe $\mu$ (2015, pp. 127-130); some-se a essa limitação fisiológica a interferência, na percepção, de elementos como a atmosfera, a qual possibilita a delimitação de paisagens por meio de um gradiente de transparência e opacidade (cf. FONTANILLE, 2015, 105-114).

Especificamente no caso dos jogos digitais, em que o jogador comanda avatares $^{29}$, o grau de mediação é menos relevante não só pelo exposto acima, mas também devido à ligação cognitiva proporcionada pelos neurônios espelho. Identificados primeiro em primatas e depois em seres humanos, essas células são ativadas em ocasiões diferentes: 1) quando uma ação é realizada; 2) quando se observa essa ação sendo realizada e 3) quando há indícios ou contiguidade lógica de uma ação a partir de estímulos sensoriais (LAMEIRA, GAWRYSZEWSKI E PEREIRA JR., 2006).

\footnotetext{
Os neurônios espelho foram associados a várias modalidades do comportamento humano: imitação, teoria da mente, aprendizado de novas habilidades e leitura da intenção em outros humanos (Gallese, 2005; Rizzolatti, Fogassi, \& Gallese, 2006) e a sua disfunção poderia estar envolvida com a gênese do autismo (Ramachandran \& Oberman, 2006). Além disso, considerando que a capacidade humana de abstrair intenção a partir da observação de conspecíficos é considerada crucial na transmissão de cultura (ver revisão em Tomasello, Carpenter, Call, Behne, \& Moll, 2005), a descoberta dos neurônios-espelho é de importância fundamental para compreendermos o que nos faz diferente de outros animais, em termos cognitivos. (Idem, p. 125)
}

\footnotetext{
${ }^{29} \mathrm{O}$ conceito de avatar pode ser facilmente explicado a partir de um elemento simples como a seta de um mouse, comum a qualquer computador atual. Ao mover o mouse, a seta também se move na mesma direção, servindo como elemento de presença do usuário dentro do computador.
} 
As relações entre o jogador, sua projeção em seu avatar, e o espaço digital, encontra-se reforçada por uma ligação que não é apenas cognitiva, mas também patêmica: diversas pesquisas atuais demonstram o forte elo afetivo entre jogador, $\operatorname{avatar}^{30}$ e espaço ${ }^{31}$, reforçando nosso argumento de similaridade semiótica entre ambientes digitais e analógicos.

Por fim, uma explicitação terminológica se faz necessária: evitamos ao longo deste tópico utilizar os termos "real" e "virtual", preferindo os vocábulos "analógico" e "digital"; tal escolha não é gratuita e se refere ao uso peculiar que a teoria semiótica de linha francesa faz desses termos. A diferença entre virtualidade e realidade se dá no campo de presença do sujeito ${ }^{32}$ : o modo virtual, como apontam Zilberberg e Fontanille (2001, p.126;131) diz respeito à distância, à vacuidade, opondo-se à proximidade e plenitude do real; dada a relação peculiar explicitada ao longo deste tópico, torna-se um contrassenso semiótico tratar espaços digitais, próximos e plenos no que toca à sua presença para o jogador, como virtuais. Sendo assim, no que diz respeito à linha argumentativa apresentada nesta tese, jogos digitais e analógicos, muito embora possam ser ontologicamente distanciados, serão semioticamente tratados, mutatis mutandis, da mesma maneira.

\section{A construção identitária e cultural do espaço}

Terminada a discussão prévia do conceito de espaço, delineando sua definição semiótica, introduziremos conceitos acerca do espaço em termos identitários e culturais, a partir do pensamento de Sara Ahmed (2006) e de Linda Alcoff (2006). Nosso foco será

\footnotetext{
${ }^{30}$ ALTON, Chris. The Play is the Thing: Virtual Embodiment and the Player/Avatar Relationship in Digital Games. Trabalho apresentado na conferência anual da Canadian Game Studies Association, Calgary, 2016.

LIVINGSTONE, Pamela; HOGSON, Jaigris. Playing in Drag: A Study on Gender Choice in Virtual and Non-Virtual Gaming. Trabalho apresentado na conferência anual da Canadian Game Studies Association, Calgary, 2016.

WALDIE, Rebecca. Identity Tourism in Virtual Space: The Virtual Identity Play Dress-Up Box. Trabalho apresentado na conferência anual da Canadian Game Studies Association, Calgary, 2016.

Os trabalhos acima foram todos apresentados na mesma mesa durante o evento.

${ }^{31}$ DOREY, Shawn. Starting Zones: Studying a Potential Intersection of Cultural Geography and Game Studies. Trabalho apresentado na conferência anual da Canadian Game Studies Association, Calgary, 2016.

${ }^{32}$ A teoria semiótica concebe quatro modos de existência da relação entre sujeito e objeto perceptível. Além dos dois citados, distinguem-se o atual, marcado pela falta, e o potencial, marcado pela inanidade.
} 
verificar como se dá a relação entre a maneira como os sujeitos moldam o mundo que os cerca a partir de suas orientações culturais diversas, bem como as reações de grupos hegemônicos às demandas de inclusão. A exposição sumária do pensamento de cada autora será feita em tópicos separados, permeada por comentários de nossa autoria balizados pela teoria semiótica, que servirá como ponte teórica entre nossa proposta e a delas.

\section{Sara Ahmed}

O que significa estar orientado? Este livro começa com a questão da orientação, de como é que acontece de encontrarmos nosso caminho em um mundo que adquire novos formatos, dependendo do lado a que nos voltamos. Se sabemos onde estamos quando nos voltamos a este lado ou àquele, então estamos orientados. Temos nosso rumo. Sabemos o que fazer para chegar a este lugar ou àquele. Estar orientado é também estar voltado na direção de certos objetos, aqueles que irão nos ajudar a encontrar nosso caminho. Esses são objetos que reconhecemos, então quando nos voltamos a eles sabemos que lado estamos encarando. Eles podem ser marcos ou outros sinais familiares que nos dão nossos pontos de ancoragem. Eles se reúnem no chão, e criam um chão sobre o qual podemos nos reunir. E no entanto, objetos se reúnem de modo bem diferente, criando diferentes chãos. Que diferença faz "aquilo" a que nos orientamos?

What does it mean to be orientated? This book begins with the question of orientation, of how it is that we come to find our way in a world that acquires new shapes, depending on which way we turn. If we know where we are when we turn this way or that way, then we are orientated. We have our bearings. We know what to do to get to this place or to that place. To be orientated is also to be turned toward certain objects, those that help us to find our way. These are the objects we recognize, so that when we face them we know which way we are facing. They might be landmarks or other familiar signs that give us our anchoring points. They gather on the ground, and they create a ground upon which we can gather. And yet, objects gather quite differently, creating different grounds. What difference does it make 'what' we are orientated toward? (AHMED, 2006, p. 1)

O parágrafo acima abre o livro Queer Phenomenology: Orientations, Objects, Others, e pode facilmente ser considerado um resumo do que Sara Ahmed propõe ao 
longo do texto. Conceitos como "orientação", "direção" e "alcance" são relativizados e remodelados com base em quatro grandes eixos: fenomenologia, gênero, sexualidade e raça. O termo "queer", presente no título e usado frequentemente como adjetivo, é convertido por Ahmed em verbo, indicando a problemática central de seu pensamento: a visada fenomenológica, de onde os conceitos principais serão tirados, será colocada em xeque de forma inusitada, "torta" e desviante, de modo a ressaltar a perspectiva dos demais eixos teóricos do livro.

Como dito pela autora, a escrita do texto já é marcada por "desvios": mesclando reflexões teóricas e relatos pessoais, não há uma filiação teórica, sendo o viés interdisciplinar a linha-guia do texto (p. 21-2). Tal estruturação dificulta a referência "direta" por via do gênero citação, uma vez que conceitos e reflexões se encontram diluídos no tecido da escrita, alongando a extensão dos trechos citados e aumentando seu número além do normalmente esperado; ao mesmo tempo, essa característica "permite" ou "licencia" apropriações transformativas e (declaradamente) dialógicas, ligadas indiretamente ao texto de Ahmed. Nesse sentido, o uso da semiótica como ponte se encontra não só valorizado como também justificado na medida em que seu caráter declaradamente redutivo e abstrato facilita a integração de conceitos em ambientes teóricos diversos.

Detenhamo-nos primeiro no conceito de "orientação", foco principal de Ahmed. Tomado fenomenologicamente, sujeitos e objetos são orientados a partir de sua copresença, isto é, não existem por si, mas co-existem, existem por e para alguém ou algo; a consciência na fenomenologia é, segundo Ahmed, não um movimento direcionado a si mesmo, mas a percepção de objetos num campo sensível, no aqui e agora (Idem, p. 25); sendo assim, ela é encarnada, sensitiva e situada (p. 27). Essa relação intrínseca é largamente trabalhada em semiótica, cujo diálogo com a fenomenologia é declarado por autores os mais diversos, seja em investigações intratextuais - em que sujeito e objeto são interdefinidos a partir de sua inserção em uma estrutura sintática de conjunção (união) ou disjunção (desunião) (GREIMAS, 2014 $4^{33}$ ) ou reflexões acerca da percepção, tópico que nos interessa de modo mais imediato neste trabalho.

Para mencionar apenas dois exemplos: o conceito de "objeto" para Peirce diz respeito a uma ruptura, a uma consciência de uma força contrária além do eu, chamada

33 "Um problema de semiótica narrativa: os objetos de valor “, pp. 31-59. 
por ele de Secundidade (PEIRCE, 1977, passim); o chamado “nível tensivo” é, também, o local de cisão entre sujeito e mundo, a partir da qual surgirá a foria - espécie de "energia" que perpassa todos os níveis do percurso gerativo do sentido, onde categorias e valores são investidos em objetos que circulam e que, posteriormente, serão discursivizados, figurativizando temas (GREIMAS; FONTANILLE, 1991, pp. 16-20). Ambos os casos dizem respeito a um nível de apreensão básico, prévio a qualquer forma de cálculo ou interferência conscientes, cujo resultado irá direcionar e dar forma à racionalização; esse é o argumento apresentado pela vertente teórica conhecida como semiótica das paixões, que pode ser resumida na seguinte formulação de Ahmed:

\begin{abstract}
Para Husserl, a interpretação do objeto como tendo esta propriedade ou aquela é um ato secundário que envolve aquilo que ele chama de "direcionalidade dobrada" (1968: 122). Primeiro, eu estou direcionada a um objeto (eu o encaro), e então eu assumo um direcionamento em relação a ele (por exemplo, eu posso ou não admirá-lo). Embora a direcionalidade seja dobrada, essa "dobrabilidade" não envolve necessariamente uma sequência no tempo: ao ver o objeto eu já o apreendo de um certo modo, como um "isto" concreto que tem qualidades que podem me atrair ou repelir, ou até mesmo me deixar indiferente, e que podem afetar como "isto" entra em meu campo de visão e se ali permanece ou passa. Voltar-me a um objeto "me" volta a esta ou àquela direção, mesmo que essa "volta" não envolva um ato consciente de interpretação ou julgamento.
\end{abstract}

For Husserl, the interpretation of the object as having this or that property is a secondary act involving what he calls a 'twofold directedness' (1969: 122). First, I am directed towards an object (I face it), and then I take a direction toward it (for instance, I might or might not admire it). While directionality might be twofold, this 'twofoldness' does not necessarily involve a sequence in time: in seeing the object I already apprehend it in a certain way, as a concrete 'it' that has qualities that might attract or repel me, or even leave me indifferent, which might affect how 'it' enters my view and wether it stays in view or passes from view. Turning toward an object turns 'me' in this way or that, even if that 'turn' does not involve conscious act of interpretation or judgement. (2006, p. 28)

A apreensão neutra do objeto inexiste; sujeitos e objetos são interdefinidos e transformados em um processo que, para Ahmed - e também para os desenvolvimentos mais recentes da semiótica -, é culturalmente determinado: reconhecemos o que somos aptos a reconhecer a partir de nossa perspectiva, nossa orientação - que aponta para 
onde podemos e devemos olhar. O espaço é constituído a partir de orientações, como vimos na seção anterior, mas Ahmed aproxima de modo claro a perspectiva topológica da interpessoal: "orientações envolvem diferentes maneiras de registrar a proximidade de objetos e outros. Orientações moldam não só como nós habitamos espaço, mas como apreendemos este mundo de habitação compartilhada, bem como a 'quem' ou 'que' direcionamos nossa energia e atenção." ${ }^{34}$ (Idem, p.3); e também liga isso à emergência da diversidade social: "Filósofos feministas, queer e de critical race nos mostraram como diferenças sociais são os efeitos de como corpos habitam espaços com outros, e enfatizaram os aspectos intercorporais da residência do corpo" . ${ }^{35}$ (Idem, p. 5).

A reflexão da autora acerca do trabalho feminino, confinado às partes traseiras de algumas casas europeias, que possibilita o trabalho intelectual masculino, feito no escritório localizado na parte da frente, é um exemplo contundente de orientação por meio de uma intersecção do topológico com o social: o filósofo (Ahmed fala especificamente dos relatos de Heidegger), que descreve sua mesa de trabalho em sua casa e a partir dela é capaz de alcançar os objetos de sua percepção e escrever a respeito deles, localiza-se na esfera do público, enquanto todo o trabalho doméstico, que possibilita a existência bem organizada de seu escritório e, por consequência, de seu trabalho filosófico, é da esfera do privado, concentrado no plano de fundo não descrito e, muitas vezes, escondido. Nas palavras da autora: "Até que ponto a filosofia depende do ocultamento do trabalho doméstico e do tempo de trabalho que se leva para reproduzir os próprios ‘materiais' do lar?”36 (Ibidem, pp. 30-1).

As posições topológicas dos cômodos de casa, com o escritório à frente, dado ao olhar público, é, desde já, uma forma de orientação que traz consequências semióticas: sendo a filosofia o exercício do ócio intelectual e lugar do diálogo público de ideias, seria possível pensar filosoficamente a partir de uma posição que não a descrita por Heidegger? Que tipo de pensamento e raciocínio sobre o sujeito e os objetos que o cercam pode surgir de uma orientação que não conhece o ócio (ao menos não da mesma forma)?

\footnotetext{
34 "orientations involve different ways of registering the proximity of objects and others. Orientations shape not only how we inhabit space, but how we apprehend this world of shared inhabitance, as well as 'who' or 'what' we direct our energy and attention toward."

35 "Feminist, queer, and critical race philosophers have shown us how social differences are the effects of how bodies inhabit spaces with others, and they have emphasized the intercorporeal aspects of body dwelling."

36 "To what extent does philosophy depend on the concealment of domestic labor and of the labor time that it takes to reproduce the very "materials' of home?"
} 
Para alguns, ter tempo para escrever, o que significa tempo para encarar os objetos sobre os quais a escrita acontece, torna-se uma orientação que não está disponível dado o trabalho contínuo de outros vínculos, que literalmente puxam você para longe. Então, se podemos ou não manter nossa orientação em direção à mesa de escrita depende de outras orientações, as quais afetam o que podemos encarar em qualquer momento dado no tempo.

For some, having time for writing, which means time to face the objects upon which writing happens, becomes an orientation that is not available given the ongoing labor of other attachments, which literally pull you away. So whether we can sustain our orientation toward the writing table depends on other orientations, which affect what we can face at any given moment in time. (Idem, p. 32)

Tempo dedicado às crianças e às tarefas de casa, no caso do trabalho de escrita feminino descrito por Ahmed nas páginas citadas, orientam o corpo em direção à escrita de modo diferente do que ocorre com o filósofo ocioso; nesse sentido, o que relegamos ao fundo e aos outros sustenta nossas orientações, seja de modo a mantê-las imperturbadas ou não.

Ampliando esse conceito para fora do âmbito de gênero, podemos pensar em classe de modo similar. Analisemos brevemente, do trabalho de Caillois (2000) já mencionado nesta tese, a seguinte afirmação acerca do jogo, que ganha sentidos mais largos em contraste com o parágrafo anterior: "O jogo é atividade de luxo e que pressupõe lazeres. Quem tem fome não joga"37 (p. 24). O comentário do autor abarca não só a questão do ócio e do querer inerente ao jogo, mas pode ser expandido a uma teorização social: é preciso pensar que tipo de apropriação/delimitação de espaço definição base de jogo para os autores discutidos aqui - seria possível a partir de tal orientação. Com o auxílio dos conceitos apresentados até o momento, já nos é possível afirmar que os resultados dessa atividade lúdica não serão os mesmos obtidos em uma situação "ideal" ou "normal" de jogo para Caillois.

Voltando à apresentação de Ahmed (2006), a existência do objeto no campo perceptivo do sujeito é marcada por uma simultaneidade no espaço e no tempo que não é fortuita, na medida em que há todo um pano de fundo, um conjunto de ações e

\footnotetext{
37 "Le jeu est activité de luxe et qui suppose des loisirs. Qui a faim ne joue pas."
} 
orientações permitindo que os actantes ${ }^{38}$ do processo co-incidam (p. 39). O interesse da intersecção entre fenomenologia e as demais teorias mobilizadas por Ahmed está justamente em se perguntar como objetos diferentes, marcados por trajetórias, determinações e orientações as mais variadas, vêm a co-incidir, ou seja, de que modo e com que marcas eles chegam até nossa percepção:

Uma chegada leva tempo, e o tempo que leva molda "aquilo" que é ao chegar. O objeto poderia até mesmo ser descrito como a transformação do tempo em forma, o que já de si poderia ser redefinido como a "direção" da matéria. O que chega não só depende do tempo, mas é moldado pelas condições de sua chegada, por como aconteceu de chegar aqui.

An arrival takes time, and the time that it takes shapes 'what' it is that arrives. The object could even be described as the transformation of time into form, which itself could be redefined as the "direction" of matter. What arrives not only depends on time, but is shaped by the conditions of its arrival, by how it came to get here. (p. 40)

Ainda mais: ocupamos objetos (e, por consequência, espaços) à medida em que nos ocupamos deles e com eles; investimos tempo e fazemos uso do que chega até nós para estender nosso alcance, tornar nossa vida mais simples. Objetos adquirem a forma do trabalho que fazemos com eles (p. 44) e/ou que podemos fazer com eles: "'utilidade' não é meramente instrumental, mas sim sobre capacidades que estão abertas ao futuro. A capacidade não está tanto 'na' ferramenta, mas depende de como a ferramenta é tomada ou 'colocada em uso'." propriedades do objeto - e, por conseguinte, do sujeito - fora de sua circulação social.

Essa conceptualização de uma história formadora de objetos, marcada por seu movimento e pelo uso, corresponde em semiótica ao que se convencionou chamar de

\footnotetext{
${ }^{38} \mathrm{Na}$ teoria semiótica de linha francesa, o termo "actante" subsume os constituintes da chamada sintaxe narrativa, esquema formal que descreve as operações de junção (conjunção/disjunção) entre sujeito e objeto. Em níveis mais superficiais de análise, actantes recebem investimentos temáticos e figurativos, bem como uma carga dêitica, convertendo-se em atores.

39 "' 'usefulness' is not merely instrumental but is about capacities that are open to the future. The capacity is not so much 'in' the tool, but depends on how the tool is taken up or 'put to use'."
} 
somação ${ }^{40}$, processo de complexificação narrativa pelo qual o objeto adquire valor para sujeitos na medida em que estes colocam aqueles em movimento; a interdefinição actancial entre sujeito e objeto se dá, portanto, na circulação narrativa, etapa imprescindível na formação de sentido para a teoria greimasiana (GREIMAS, 2014; GREIMAS; FONTANILLE, 1991). A discussão de Ahmed (2006) permite que extrapolemos a abstração semiótica para compreender como grades de leitura circulam como ferramentas ${ }^{41}$ : signos e demais alongamentos semióticos submetem-se a esses mesmos princípios, mesmo quando se desconsidera a materialidade pela qual se exprimem. Sendo assim, a questão da historicidade e orientação de sujeitos e objetos é capaz de problematizar as abordagens proceduralistas de jogo, como a de Bogost (2006; 2007; 2011). Voltaremos a esta questão, de forma diferente, na próxima seção.

Orientação e ocupação se relacionam por meio do ajuste: "Quando coisas estão orientadas, nós encaramos o lado certo; em outras palavras, os objetos ao redor do corpo permitem que o corpo em si seja estendido. Quando coisas estão orientadas, nós estamos ocupados e atarefados"42 (AHMED, 2006, p. 51); é preciso que sujeito e objeto se "encaixem" para que ocorra ação. Essa situação não é fortuita, uma vez que objetos tendem em direção a determinados sujeitos e não a outros, com base nas tendências dos sujeitos para os quais são destinados; objetos podem, inclusive, tomar a forma daqueles a quem se orientam (Ibidem). Neste ponto, Ahmed retoma a questão de espaço, atribuindo a esse conceito a mesma propriedade dos objetos: dependendo da possibilidade de encaixe, espaços podem não se dar à ocupação de qualquer corpo. Sujeitos impossibilitados de se ocupar com ferramentas e utilizá-las para estender suas capacidades são, nesse sentido, desorientados.

Essa formulação retoma a proposta introdutória de Ahmed: "o livro visa mostrar como corpos são generificados, sexualizados e racializados por como se estendem no espaço, como uma extensão que faz diferença entre 'esquerda' e 'direita', 'frente' e 'trás', 'cima' e 'baixo', bem como 'perto' e 'longe'”,33 (Idem, p. 5), além de ecoar a

\footnotetext{
${ }^{40} \mathrm{~A}$ acepção dicionarizada em português, relativa à biologia, não corresponde ao uso que se faz de "somação" em textos de semiótica francesa. Trata-se de um galicismo, transposto de sommation, que significa o processo de "urgir", "colocar em movimento".

${ }^{41}$ Cf. seção 1 deste capítulo.

42 "When things are orientated, we face the right way; in other words, the objects around the body allow the body itself to be extended. When things are orientated, we are occupied and busy."

43 "the book aims to show how bodies are gendered, sexualized, and raced by how they extend into space, as an extension that differentiates between 'left' and 'right', 'front' and 'behind', 'up' and 'down', as well as 'near' and 'far'."
} 
reflexão acerca do trabalho feminino e sua posição topológica - mulheres, por serem orientadas a determinados objetos domésticos, não ocupam a posição frontal da casa, destinada ao ócio filosófico e repleta de móveis e instrumentos que entram em conflito com as orientações de seus corpos; objetos não tendem a elas uma vez que elas não tendem a eles.

Semioticamente, isso diz respeito à relação entre percepção e performance: sendo a base de geração do sentido a separação de si e do mundo, posteriormente alongada e complexificada por somações que colocam sujeitos e objetos em movimento, a impossibilidade de se mover ou se apropriar do que quer que seja tem por efeito a redução da chamada "competência modal", pressuposto lógico de qualquer performance: sem que o sujeito possa ou saiba fazer, ou sem que acredite em sua competência, tanto o fazer quanto o ser encontram-se impossibilitados.

Por fim, em termos de orientação, o fator tempo, na forma de repetição, é fundamental: corpos, objetos e espaço são moldados a partir do uso contínuo e repetido, determinado por orientações específicas que deixam marcas e abrem caminhos ao mesmo tempo em que fecham outros; o que corpos efetivamente fazem delimita o que podem fazer. Paradoxalmente, a repetição faz o trabalho desaparecer - ações exercidas por atletas profissionais nos parecem não requerer esforço, prévio ou concomitante ao ato -, neutralizando as orientações e dando-lhes uma aparência intrínseca e imanente aos corpos; nesse sentido, gênero, sexualidade e raça - todas formadas a partir de orientações e extensões corporais recorrentes no espaço e no tempo - passam a ser reconhecidas como naturais. (Idem, pp. 56-60)

Retomemos uma questão relativa à semiótica de linha francesa: a análise recorrente de narrativas consideradas canônicas - como os contos de fada - levou diversos teóricos a postular, nos anos 60 e 70, um modelo imanente de produção de sentido, passível de aplicação analítica a todo e qualquer tipo de sistema semiótico; atualmente, os avanços da semiótica das paixões - cujo caráter cultural é exaustivamente declarado por Greimas e Fontanille (1991) - e do seu desdobramento tensivo demonstram que a percepção modifica esse esquema, não mais natural e sim cultural. Assim como o processo de apagamento histórico descrito por Ahmed (2006), relativo à história dos corpos, modelos cognitivo-semióticos naturalizam-se e universalizam-se por recorrência e superexposição. 
Passemos, agora, à discussão dos demais pontos apontados por Ahmed: gênero, sexualidade e raça. Os dois primeiros encontram-se interligados, na medida em que a heterossexualidade compulsória, presumida como orientação normal de onde a homossexualidade desvia, pressupõe a construção do feminino como extensão negativa $^{44}$ do masculino, como um objeto a ser utilizado e preenchido (Idem, p. 71). No trecho a seguir, em que se discute um caso de Freud sobre sexualidade feminina, essa relação está bastante clara:

$\mathrm{Na}$ interpretação de Freud, o desejo da mulher de ter o filho do pai é frustrado, o que a leva a se afastar do pai e de homens em geral. Essa leitura coloca o desejo lésbico como compensação pela falha do desejo heterossexual. Como argumenta Judith Roof, "a sexualidade lésbica é definida como um derivativo masculino, um produto ou uma afirmação do desejo incestuoso pelo pai" (1991: 203) Tais desejos, que estão "fora da linha" são, portanto, vistos como causados pela falha de um desejo.

In Freud's interpretation, the woman's wish to have the father's child is disappointed, which leads her to turn away from the father and from men in general. This reading places lesbian desire as a compensation for the failure of heterosexual wish. As Judith Roof argues, 'lesbian sexuality is defined as a male derivative, a product or an affirmation to of failed incestuous desire for the father' (1991: 203) Such desires, which are 'off line' are therefore seen as caused by the failure of a wish. (Idem, p. 76)

Nessa análise, Ahmed já havia expandido a figura do pai para a de representante da família, conceito que orienta corpos na direção da reprodução da linhagem e de papeis sociais esperados de cada membro - o patriarca, a esposa submissa e recatada, as filhas prendadas, os filhos corajosos e cheios de vida; o caso citado chega até Freud como um pedido de correção da filha que não preza os valores familiares ao sair da linha de conduta esperada (Idem, p. 74). Sexualidade e gênero se ligam na tentativa de endireitar o desvio queer por meio da heteronormatividade, uma vez que lésbicas são "masculinizadas" para tornar sua orientação explicável a partir da expansão negativa mencionada acima (Idem, pp. 71-2); o mesmo vale para a divisão entre homossexuais masculinos ativos e passivos, bem como a categoria "afeminados" - "quem é o homem

\footnotetext{
${ }^{44}$ No sentido estruturalista do termo, em que o negativo se define como aquilo que o positivo não é.
} 
da relação?" é uma pergunta frequente que ressalta a tentativa de correção, cognitivamente ao menos. Em suma, o direcionamento para o mesmo ao invés do oposto ameaça a própria constituição de gênero.

O conceito de genealogia, segundo Ahmed (Idem, p. 83), é o catalisador da normatividade que envolve gênero e sexualidade; é por meio do desejo de conservar as linhas verticais (descendência) e horizontais (casamento) da árvore genealógica que as orientações são repetidas à exaustão, tornando-se familiares a ponto de qualquer desvio adquirir uma densidade de sentido ${ }^{45}$ que destaca o desviante, tornando-o ruído. 0 familiar se expande pela ação recorrente, moldando o espaço ao moldar os sujeitos e objetos que nele habitam; a partir disso, espaços adquirem gênero e sexualidade: além dos exemplos da topologia doméstica, pensamos na classificação de determinadas casas noturnas como "bares gay", em que corpos homossexuais podem se expandir sem medo de represálias em oposição às vias públicas, de expansão heterossexual - o fato de desvios de gênero ou sexualidade causarem ruído e impedirem o alcance na esfera pública revela a orientação dos espaços a partir dos corpos que historicamente os moldaram como espaços normativos. Mais além: a normatização é parte constitutiva do que nos permite perceber espaços e corpos como coerentes; vemos o que somos orientados a ver, uma vez que a orientação não se dá apenas em direção à norma, mas em torno dela (Idem, p. 91-92) - o desviante é tido como falho, incongruente consigo mesmo.

A polissemia da palavra "normalidade" vem a calhar nessa discussão: tanto em seu sentido jurídico ("o processo foi executado dentro da normalidade"), quanto no sentido de neutralidade, espaços públicos heterossexualizados dizem respeito tanto à norma quanto ao normal: reforçam os estereótipos e práticas recorrentes ao mesmo tempo em que se neutralizam, adquirindo um caráter não-marcado - não há "bares hétero"; estes são apenas bares. Nesse sentido, a heterossexualidade não é uma orientação cujo alvo é exclusivamente composto de objetos sexuais ou afetivos, mas funciona como um pano de fundo que está por trás da organização social como um todo; um horizonte ao qual não se presta atenção, mas que possibilita ou inviabiliza certos cursos de ação sustentando-se, ao mesmo tempo, por eles (Idem, p. 87).

\footnotetext{
${ }^{45} \mathrm{Cf}$. conceito de barissemia, na seção 1.
} 
Esse caráter normativo de espaços orienta o alinhamento de gênero e sexualidade padrões de modo compulsório (Idem, p. 84), desorientando por consequência aqueles que não desejam ou não conseguem orientar-se de acordo com a normalidade; uma estrutura narrativa se delineia: sujeitos que não se sentem atraídos por objetos de valor adequados ao regime de crença socialmente aceito são sancionados negativamente, tendo seu acesso a outros objetos negado; em contrapartida, aqueles que se adequam recebem sanções positivas e expandem seu alcance. A circulação de valores no espaço é, ao mesmo tempo, determinada pela norma e sua determinante, uma vez que a neutralização se dá justamente pela repetição e a torna uma compulsão, potencialmente evitável a um alto custo.

O mecanismo de sanção, no entanto, funciona para Ahmed como evidência da culturalidade da orientação normativa: "A ideia mesma de que corpos 'têm' uma orientação natural é exposta como fantasia na necessidade de imposição dessa orientação, ou de sua manutenção como requerimento social para uma subjetividade inteligível" ${ }^{46}$ (Idem, p. 85). A partir disso, podemos concluir que a afirmação de formas de orientação divergentes representam perigo, na medida em que corpos desviantes são expandidos e modificam os espaços por onde passam, seja dividindo objetos antes apenas alcançados por aqueles que partilham das orientações normatizadas, seja exigindo uma retração dos corpos dentro do padrão - retornaremos a essa questão no próximo tópico, por meio do trabalho de Alcoff (2006).

Saindo do eixo gênero-sexualidade, Ahmed (2006) define racismo como "uma história contínua e não terminada, que orienta corpos em direções específicas, afetando como eles 'tomam' espaço" ${ }^{\$ 7}$ (p. 111), o que está de acordo com o que foi dito sobre sexualidade; no entanto, a diferença reside na questão do desvio: não existe normatização em direção a outras raças, na medida em que, assim como gênero, esse aspecto é visto como algo inerente e pertencente a sujeitos; corpos racializados, no entanto, têm seu lugar determinado. A partir de uma reflexão da obra de Fanon, Ahmed afirma que

\footnotetext{
46 "The very idea that bodies 'have' a natural orientation is exposed as fantasy in the necessity of the enforcement of that orientation, or its maintenance as a social requirement for intelligible subjectivity."

47 "an ongoing and unfinished history, which orientates bodies in specific directions, affecting how they 'take up' space."
} 
o racismo "impede" corpos negros que habitam o espaço ao se estender por objetos e outros; a familiaridade do "mundo branco", como sabemos implicitamente, "desorienta" corpos negros a ponto de pararem de conhecer onde encontrar coisas - reduzidos como são a coisas entre coisas. $O$ racismo garante que o olhar negro volte ao corpo negro, o que não é um retorno amável mas em vez disso segue a linha do olhar branco hostil. A desorientação afetada pelo racismo diminui as capacidades para ação. (realces nossos)

racism "stops" black bodies inhabiting space by extending through objects and others; the familiarity of 'the white world', as a world we know implicitly, 'disorients' black bodies such that they cease to know where to find things reduced as they are to things among things. Racism ensures that the black gaze returns to the black body, which is not a loving return but rather follows the line of the hostile white gaze. The disorientation affected by racism diminishes capacities for action.(Idem, p. 111)

Nesse sentido, a imposição é de uma inferioridade vista como inerente, e moldada por histórias de colonialismo. Racializar é criar Outros diferentes de nós, exóticos e/ou inferiores; a questão da cor da pele em si é, ironicamente, secundária, uma vez que a categoria "branco" se opõe a "não-brancos" de maneira diferente e em épocas diferentes, a ponto de alguém (ou algo) considerado portador de branquitude em um país como Brasil pertencer a uma das diversas categorias não-brancas nos Estados Unidos latinos, independente da cor da pele, não partilham de branquitude, que é vista, portanto, como o atributo não-marcado pela inferioridade.

Funcionando como uma espécie de "supra-genealogia", a orientação racial é passada como herança:

herdamos a alcançabilidade de alguns objetos, aqueles que nos são "dados" ou pelo menos tornados disponíveis a nós dentro da casa familiar. Não estou sugerindo que a "branquitude" seja um desses "objetos alcançáveis" mas sim que a branquitude é uma orientação que coloca certas coisas ao alcance. Por objetos, incluiríamos não só objetos físicos, mas também estilos, capacidades, aspirações, técnicas, até mesmo mundos. Ao colocar certas coisas ao alcance, um mundo adquire sua forma; o mundo branco é um mundo orientado "ao redor" da branquitude. Este mundo é, também, "herdado" como lar: é um mundo moldado por histórias coloniais, que afetam não somente como mapas são 
desenhados, mas os tipos de orientações que temos na direção de objetos e outros. A raça se torna, neste modelo, uma questão do que está ao alcance, o que está disponível a se perceber e com o que podemos fazer "coisas".

we inherit the reachability of some objects, those that are 'given' to us or at least are made available to us within the family home. I am not suggesting that 'whiteness' is one such 'reachable object' but rather that whiteness is an orientation that puts certain things within reach. By objects, we would include not just physical objects, but also styles, capacities, aspirations, techniques, even worlds. In putting certain things in reach, a world acquires its shape; the white world is a world orientated 'around' whiteness. This world, too, is 'inherited' as a dwelling: it is a world shaped by colonial histories, which affect not simply how maps are drawn, but the kinds of orientations we have toward objects and others. Race becomes, in this model, a question of what is within reach, what is available to perceive and to do "things" with. (Idem, p. 126)

A branquitude é herdada e partilhada como atributo de corpos, uma passagem de linhas de conduta que não se dá necessariamente pelo contato direto: a imprensa e a mídia em geral, por exemplo, funcionam como direcionamento coletivo na medida em que orientam pessoas participantes de um mesmo grupo a um objeto em comum - tratase de um alongamento semiótico nos termos do Groupe $\mu$ (2015).

Assim como no caso do eixo gênero-sexualidade, essa expansão conceitual torna possível falar sobre a espaços e instituições racializados, que acumulam pontos de extensão e adquirem a pele dos corpos que ali habitam. Uma instituição branca é, portanto, derivada de uma modelagem específica: "corpos brancos reúnem-se e ganham coerência para formar as arestas de tais espaços" ${ }^{48}$ (AHMED, 2006, p. 133) São, portanto, locais onde é possível aos membros da branquitude ampliar seu alcance e mover-se confortavelmente. Os não-brancos que habitam esses espaços tornam-se ou invisíveis - como um objeto a mais que pode ser usado - ou hipervisíveis - destacandose negativamente (Idem, p. 136).

Após essa longa exposição do ponto de vista de Ahmed, concluímos que os três aspectos mencionados por ela são elementos essenciais da constituição territorial do

\footnotetext{
48 "white bodies gather and cohere to form the edges of such spaces."
} 
espaço; o conceito de território diz respeito a uma delimitação espacial imprecisa e cultural, cujos limites estão sempre em tensão com a necessidade de serem, ao mesmo tempo, ultrapassados e reforçados (FONTANILLE, 2015, p. 229). Essa definição semiótica analisada como uma forma de vida por Fontanille - isto é, um modelo de persistência que regula estratégias, práticas, objetos, textos e signos (Idem, passim) -, dialoga com nossa leitura de Ahmed (2006), ao tratar do conceito como uma transformação de espaço empreendida pela iteração de práticas reflexivas: "As práticas do passado deixaram marcas profundas no território (elas as 'enterraram' em sua morfologia mesma), e as práticas contemporâneas as desenterram e as reatualizam." ${ }^{49}$ (FONTANILLE, 2015, p. 236) Trata-se de uma questão estrutural que alimenta manifestações figurativas (ao mesmo tempo em que é manifestada por elas), cujo efeito mais frequente é a manutenção do status quo:

Essa dimensão figurativa participa da legitimação do controle [...], na medida em que ela confere um plano de expressão para as propriedades sobre as quais repousa a adequação entre o domínio e o actante. Ela se exprime ao projetar nas figuras do mundo natural as respostas do território aos desejos e às necessidades de seus ocupantes. Esse plano de expressão consolida, por consequência, a legitimidade da apropriação do território e do exercício do poder, ao inscrevê-lo "nas coisas em si" e em sua percepção pelos ocupantes. $O$ elo de identificação entre o grupo e o espaço é da ordem do "poder ser" (o possível) e ele se converte em "poder fazer" (o controle).

Cette dimension figurative participe à la légitimation du contrôle [...], dans la mesure où elle procure un plan d'expression pour les propriétés sur lesquelles repose l'adéquation entre le domaine et l'actant. Elle exprime en les projetant dans les figures du monde naturel les réponses du territoire aux attentes et aux besoins de ses occupants. Ce plan d'expression conforte par conséquent la légitimité de l'appropriation du territoire et de l'exercice du pouvoir, en l'inscrivant "dans les choses mêmes" et dans leur perception par les occupants. Le lien d'identification entre le groupe et l'espace est de l'ordre du 'pouvoir être' (le possible) et il se convertit en 'pouvoir faire' (le contrôle). (Idem, p. 239)

\footnotetext{
49 "Les pratiques d'hier ont laissé des empreintes profondes dans le territoire (elles les ont 'enfoui' dans sa morphologie même), et les pratiques contemporaines les désenfouissement et les réactualisent."
} 
Espaços normativos, ao negar a possibilidade de expansão aos corpos desviantes, convertem sua dificuldade de existência em uma impossibilidade de ação, como já discutimos; o que nos interessa é a constatação de que contextos pós-coloniais (ou ao menos assim declarados) lidam frequentemente com uma rejeição explícita, largamente debatida na mídia, a políticas afirmativas, cujo objetivo é justamente a expansão do campo de ação de minorias - trata-se, em nossa leitura, de uma tentativa de proteger do desviante as trincheiras do território da normalidade. Esse é o foco do trabalho de Alcoff (2006), cuja discussão iniciaremos agora.

\section{Linda Alcoff}

E ele sabia bem, por ter passado muitos anos na Flórida como estudante e, mais tarde, como professor, que sua pele marrom e sotaque hispânico não Ihe faziam nenhum favor na "terra dos livres" apesar de seus méritos. Com um título de mestre, o único emprego que conseguiu nos anos 1950 foi de entregador de sorvete em cima de uma bicicleta.

And he was well aware from having spent many years in Florida as a student and later as a professor that his brown skin and Spanish accent did him no favors in the 'land of the free' despite his accomplishments. With a master's degree, the only job he could find in the 1950s was riding a bicycle delivering ice cream. (ALCOFF, 2006, p. vii)

Extraída do prefácio de Visible Identities: Race, Gender, and the Self, essa situação vivida pelo pai de Alcoff dá o direcionamento das questões trabalhadas no livro: identidades em contexto estadounidense e o ataque que políticas de ação afirmativa sofrem de várias frentes, sob o pretexto de que o conceito de identidade remete a uma formação histórica que ficou efetivamente no passado e impede, no presente, a união e estabilidade político-social.

Levando em consideração prioritariamente gênero e raça, classificadas pela autora como "identidades visíveis" - i.e., atreladas à crença de que características físicas (traços, presença de determinados órgãos, sotaques etc.) são passíveis de manifestar a "verdade" do ser -, Alcoff argumenta que tais características identitárias tanto são intrínsecas ao modo como sujeitos percebem o mundo quanto determinam em grande 
parte suas escolhas, caminhos e chances de sucesso, sendo impossível pensar o sujeito fora de seu contexto.

Antes de entrar na teoria, é preciso discutir uma aparente diferença de perspectiva entre Alcoff e Ahmed, que reside justamente na relação entre o corpo físico e os conceitos de gênero e raça: enquanto para esta, como vimos, tais aspectos são analisados como uma forma de orientação no tempo e no espaço que é atribuída ao corpo, para aquela eles dependem do corpo e de traços visíveis, fazendo parte da ontologia social constitutiva do sujeito. Em nossa leitura, no entanto, o composto "ontologia social" difere do uso conceitual que demos à palavra até então, uma vez que o especificador "social" que o acompanha confere um caráter semiótico a ele; Alcoff, citando Clara Rodriguez, aponta que latinos de pele mais clara podem ser confundidos com brancos e, consequentemente, ser tratados de modo melhor até o momento em que a hispanicidade é reconhecida - sotaques são percebidos após o reconhecimento em pessoas que "não os tinham" antes (ALCOFF, 2006, p. ix). Trata-se, portanto, de uma visada não oposta, mas complementar: se para Ahmed a repetição de orientações produz tais características e pode moldar o corpo, para Alcoff as marcas são mecanismo de reconhecimento e atribuição de um "ser", seja de modo reflexivo (o sujeito se enxerga a partir das marcas) ou não.

Tendo delimitado as diferenças de abordagem de que partem os textos, iniciemos a discussão da primeira parte do livro de Alcoff. Dividido em quatro seções (sendo três delas destinadas à análise de gênero, raça e da especificidade latina), apenas a primeira - dedicada à problematização das bases por trás das oposições a políticas afirmativas nos interessa diretamente. A autora inicia sua exposição a partir da constatação de um (falso) paradoxo: ao mesmo tempo em que academicamente se reconhece a importância de considerar fatores identitários nos mais diversos estudos - o que consequentemente elimina a possibilidade de se conceber um Homem abstrato -, percebe-se um aumento nos ataques ao conceito de identidade vindos da política e da academia. "A noção de que o 'Homem' genérico foi um escudo retórico para a agência de um único subgrupo pode ser amplamente aceita, mas muitos ainda sentem saudades do discurso de universalidade genérica, dos dias em que diferenças podiam ser ignoradas." ${ }^{50}$ (Idem, p. 5)

\footnotetext{
50 "It may be widely conceded that generic 'Man' was a rhetorical cover for the agency of a single subgroup, but many still pine for the lost discourse of generic universality, for the days when differences could be disregarded."
} 
Para Alcoff, muito embora haja críticas pertinentes relativas à tendência à homogeneização de grupos em contextos que advogam a favor do conceito de identidade, a maior parte das críticas não o define, nem apresenta qualquer tipo de dado ou argumento sólido contra ele; trata-se de uma recusa peremptória a qualquer análise identitária, por mais fundamentada que seja. A origem dessa fobia é traçada ao trabalho de Arthur Schlezinger, que acusa o "culto à etnicidade" dos anos 60 de interromper o progresso dos Estados Unidos em direção a uma nação unificada, na qual todas as diferenças entre os sujeitos que a compõem são apagadas; trata-se, em suma, do mito da América como "melting pot" (Idem, p. 16). A contradição dessa ideia reside no fato de que Schlezinger coloca os valores e a cultura europeias acima dos demais; os Estados Unidos são, paradoxalmente, vistos como uma extensão europeia com estilos de vida e valores mais elevados, os quais devem ser preservados em sua hegemonia:

Schlesinger argumenta que a "diferença crucial" entre a tradição Ocidental e outras tradições é que o Ocidente produziu antídotos para seus problemas. Todas as culturas "fizeram coisas terríveis", diz ele, mas "quaisquer que sejam os crimes específicos da Europa, esse continente é também a fonte - a única fonte daquelas ideias libertadoras ... às quais o mundo aspira hoje. Essas são ideias europeias, não asiáticas, africanas, ou do Oriente Médio, a não ser por adoção” (127, ênfase no original) Schlesinger, como Huntington, Pat Buchanan, Peter Brimelow e outros opositores do multiculturalismo, caem na contradição de argumentar que devemos nos opor ao "culto da etniticidade" porque, por um lado, os "Estados Unidos" são um recipiente de fusão [melting pot] onde as culturas originárias se dissolvem em proveito de uma nova unidade, mas por outro lado, são os valores europeus especificamente que tornaram grande esta nação e devem permanecer dominantes.

Schlesinger argues that the 'crucial difference' between the Western tradition and other traditions is that the West produced antidotes to its problems. Every culture 'has done terrible things,' he claims, but 'whatever the particular crimes of Europe, that continent is also the source-the unique source - of those liberating ideas ... to which most of the world today aspires. These are European ideas, not Asian, nor African, nor Middle Eastern ideas, except by adoption' (127, emphasis in original). [...] Schlesinger, like Huntington, Pat Buchanan, Peter Brimelow, and other opponents of multiculturalism, falls into the contradiction of arguing that 
we should oppose the 'cult of ethnicity' because, on the one hand, 'America' is a melting pot where originary cultures are dissolved in favor of a new unity, but on the other hand, because it is the specifically European customs and values that have made this nation great and must remain dominant. (Idem, p. 17)

Segundo a autora, ao fim e ao cabo, a defesa do "melting pot" é um desejo de supremacia dos valores europeus formadores da América e apagamento da história de opressão sofrida por diversos grupos, intimamente ligada à construção de suas identidades. Derivam dessa perspectiva os diversos casos de racismo e preconceitos étnicos sofridos por minorias que variam à medida em que os Estados Unidos substituem determinados inimigos políticos por outros - os muçulmanos são a "bola da vez", hostilizados de maneira explícita pelas políticas de Donald Trump decretadas menos de 30 dias após sua posse, em janeiro de 2017.

Outra base para a luta contra as identidades reside na ideologia liberal, que preconiza o ser humano como uma abstração universal capaz de objetificar sua cultura e identidades étnicas, com neutralidade para debater e participar da vida pública com racionalidade; tal ideal, identificado por Alcoff com a obra de Descartes e Kant, é uma das bases do processo de modernidade e serve como base à classificação de diferentes culturas como "avançadas" ou "atrasadas" (Idem, p. 22). Um dos principais pontos apresentados pela autora em sua crítica à base filosófica reside no domínio da ideia moderna de racionalidade como algo procedural, e não substantivo, i.e., uma faculdade redutível a processos e não determinada por contextos, imposições materiais ou limitações emotivas; pressupondo um controle não só de si, como também do mundo exterior. (Idem, pp. 49-54)

A partir disso, Alcoff demonstra a forte relação entre essa ideologia, a herança filosófica cartesiana e a conquista colonial, aproximando-se, em nossa leitura, do trabalho de Grosfoguel e Castro-Gómez (2007). A redução do material a processos formadores de sentido e o colonialismo já foi discutida anteriormente, o que reforça a pertinência do diálogo entre o trabalho de Alcoff (2006) com a ludologia: os mecanismos de apagamento de questões identitárias, já associados a um esforço ativo de manutenção de hegemonias, têm a mesma base filosófica da abordagem proceduralista do jogo, e não é coincidência que esse ramo da ludologia sirva, de modo não 
necessariamente intencional, como escudo conceptual que mantém intactas determinadas estruturas de poder no campo lúdico.

Seja no campo político, seja no campo filosófico, o principal obstáculo às questões identitárias reside na crença de que a identidade, por seu caráter material e histórico, compõe em si um obstáculo à aproximação racional de qualquer objeto. Alcoff afirma que essa via argumentativa é composta de duas falácias: 1) a crença de que pode existir racionalidade livre de conjuntos de valores e interesses localizados; e 2) uma ideia de identidade como um conjunto estanque e limitador de interesses e valores aos quais sujeitos adeririam "voluntariamente", isto é, como um conjunto de características das quais podemos escolher (ou não) nos despir.

Nesse contexto de racionalidade ligada à abstração do sujeito de sua identidade, a impossibilidade de transcendê-la é tratada como um desvio a ser corrigido para que a sociedade caminhe em direção a uma harmoniosa igualdade; essa aproximação nos interessa pelo diálogo com o trabalho de Ahmed (2006), e reforça a associação entre a ideologia liberal de apagamento e existência das desigualdades constitutivas da formação de minorias sociais. Como aponta Alcoff (2006), identidades formadas a partir de contexto de opressão - como a racial, diretamente derivada da colonialidade - não podem ser enquadradas numa definição de adesão voluntária, uma vez que são impostas e frutos de relações que independem do indivíduo (p. 38). Um paradoxo da ideia liberal aparece quando se constata que, em ambientes supostamente regidos por uma racionalidade isenta, aspectos como gênero e raça são levados em conta para validar argumentos (Idem, p. 24); exemplos claros são os casos de mansplanning ${ }^{51}$ dirigidos a profissionais mulheres em diversas áreas, incluindo a acadêmica.

Similar à crítica liberal, as mais diferentes vertentes políticas organizadas sob o rótulo de "Esquerda" problematizam políticas identitárias por desvio de foco do problema "real": a opressão de classe, que subsume todas as outras. Essa visão é, para Alcoff, antiquada e incoerente, uma vez que

não se pode, na imaginação ou na prática, dedicar-se a "demandas de classe" como se a classe trabalhadora tivesse um conjunto de interesses materiais unificados e homogêneos. Não faz sentido político nem teórico imaginar uma

\footnotetext{
${ }^{51}$ Quando um homem explica algo óbvio a alguma mulher, por considerá-la incapaz de compreender aquilo sozinha por ser mulher ou quando considera que enquanto mulher ela não pode conhecer bem o assunto, independente de ser ou não especialista.
} 
classe trabalhadora indistinta exigindo uma fatia maior do bolo para ser dividida entre seus membros com a mesma proporcionalidade de remuneração que existe atualmente baseada em racismo e machismo.

one cannot either imaginatively or practically pursue 'class demands' as if the working class has one set of united and homogeneous material interests. It makes neither political nor theoretical sense to imagine an undifferentiated working class demanding a larger share of the pie, to be divided among them with the same ratios of remuneration as currently exist based on racism and sexism. (Idem, p. 27)

A tentativa de reduzir todas as opressões a uma "superopressão", que, quando eliminada, anularia todas as outras é mais uma maneira de normalizar o desvio causado pelas questões raciais e de gênero, ignorando o papel crucial da identidade na formação subjetiva. Além disso, gera a impressão de que oprimidos são incapazes de oprimir outras minorias, leitura facilmente derrubada quando se consideram contextos como os do Brasil: pertencentes a uma categoria desvalorizada pela divisão colonial, o povo brasileiro figura entre os mais machistas, LGBTQfóbicos e racistas do mundo ${ }^{52}$.

Outro problema, central para esta tese, reside no fato de que interações em jogos digitais, pertencentes a um domínio do ciberespaço majoritariamente ocupado por membros de classes mais favorecidas, são marcadas por opressão de gênero, sexualidade e raça, independentemente de a interação ser mediada por avatares que neutralizariam, hipoteticamente, as marcas identitárias de cada um. Sendo assim, a conclusão de que, a partir da eliminação de uma opressão (seja ela qual for), uma reação em cadeia se deflagaria, derrubando uma a uma todas as demais formas de desigualdade, não se verifica.

Opondo-se às duas falácias apontadas, a autora propõe que identidade seja definida em termos muito parecidos com os de Ahmed (2006); para Alcoff (2006):

\footnotetext{
52 https://nacoesunidas.org/onu-feminicidio-brasil-quinto-maior-mundo-diretrizes-nacionais-buscamsolucao/ (Acesso em Julho de 2019) http://www1.folha.uol.com.br/paineldoleitor/2014/11/1550693-brasil-lidera-ranking-de-mortes-porIgbtfobia-afirma-pesquisador.shtml (Acesso em Julho de 2019) http://brasil.elpais.com/brasil/2016/05/10/politica/1462895132_579742.html (Acesso em Julho de 2019)
} 
A identidade não é meramente aquilo que é dado a um indivíduo ou grupo, mas é também um modo de habitar, interpretar, e trabalhar sobre, tanto coletiva quanto individualmente, uma localização social e uma história de grupo objetivas. Poderíamos, então, de uma maneira mais perspicaz, definir identidades como experiências vividas posicionadas ou localizadas nas quais tanto indivíduos quanto grupos colaboram para construir sentido em relação a experiências históricas e a narrativas históricas. Sob esse ponto de vista, poder-se-ia sustentar que quando eu sou identificado, é o meu horizonte de agência que é identificado. Portanto, identidades não são vividas como um conjunto de interesses discretos e estáveis, mas como um local de onde devemos nos engajar no processo de fazer sentido e, assim, de onde nos abrimos para o mundo. (Realces nossos)

[l]dentity is not merely that which is given to an individual or group, but is also a way of inhabiting, interpreting, and working through, both collectively and individually, an objective social location and group history. We might, then, more insightfully define identities as positioned or located lived experiences in which both individuals and groups work to construct meaning in relation to historical experience and historical narratives. Given this view, one might hold that when I am identified, it is my horizon of agency that is identified. Thus, identities are not lived as a discrete and stable set of interests, but as a site from which one must engage in the process of meaning-making and thus from which one is open to the world. (Idem, p. 42-3, realces nossos)

Esse conceito é alinhado à ideia de que não é possível haver racionalidade - nem mesmo no sentido cartesiano/kantiano - a partir do nada, sem qualquer tipo de referência a um sistema de valores:

$\mathrm{Na}$ medida em que a racionalidade pode ser definida como juízos comparativos feitos a partir de um horizonte substantivo dado, e que se permite que até mesmo os critérios do juízo em si [...] sejam constituídos apenas dentro de um horizonte dado, então a identidade cultural não é uma ameaça a priori à racionalidade. [...] A deliberação racional sempre ocorre em um campo de significados e práticas, e é apenas dentro desse campo que o caráter racional de um juízo deliberativo pode ele mesmo ser julgado. 
To the extent that rationality can be defined as comparative judgments made from within a given substantive horizon, and one allows that even the criteria of judgment itself [...] is constituted only within a given horizon, then cultural identity is no a priori threat to rationality. [...] Rational deliberation always occurs within a field of meanings and practices, and it is only within this field that the rational character of a deliberative judgment can itself be judged. (Idem, p. 56)

A partir dessa reorientação, a questão que nos interessa no texto de Alcoff é a da constatação de que as críticas e oposições a políticas identitárias dizem respeito, em grande parte, não a uma tentativa de estabelecer medidas gerais, que beneficiariam a todos, mas a uma afirmação de supremacia; a identidade branca é o foco das políticas ditas "neutras". A autora nos dá como exemplo o caso de uma universidade estadounidense que sofreu ameaças de retirada de investimento por parte de um de seus doadores, no valor de cem mil dólares, caso a instituição acatasse a demanda de um grupo indígena da Dakota do Norte pela mudança do mascote, considerado ofensivo; a importância dada ao fato pelo doador, um homem branco, revela que

a política identitária em jogo neste caso é a identidade branca, na qual a
branquitude é associada ao privilégio de nomear outros, de escolher a própria
forma de gracejo discursivo com autonomia total, assim como as narrativas de
vanguarda das culturas anglo-europeias que retratam o resto do mundo como se
existissem em diversos estágios de "atraso". the identity politics at play in this case is white identity, in which whiteness is associated with the privilege to name others, to choose one's own form of discursive banter with total autonomy, as well as with vanguard narratives of Anglo-European cultures that portray the rest of the world as existing in various stages of 'backwardness'. (Idem, p. 33)

Retomando a discussão feita no final do tópico anterior a respeito do conceito de território, podemos ler o exemplo de Alcoff sob a chave de uma disputa comparável à bélica pela dominância de um espaço estratégico que não pode de maneira alguma ser perdido para o oponente; a sanção econômica utilizada como meio de coagir a universidade em questão é comparável a práticas políticas como a do embargo, 
impedindo que o grupo menos privilegiado socialmente possa negociar. Estamos diante de um exemplo de entrincheiramento simbólico de um espaço de domínio semiótico que, para o grupo dominante, está ameaçado - fenômeno que nos interessa por se relacionar de modo bastante contundente com diversos casos de machismo, homofobia e racismo dentro da cultura nerd. A teoria de Alcoff, que relacionamos com a de Ahmed (2006), nos ajudará a pensar tais tensões no campo dos jogos, que retomaremos agora.

Para iniciar essa discussão, vejamos um episódio que beira o cômico: o do usuário Razor 007, que criou um tópico em fevereiro de 2016 em um fórum online sobre o jogo analógico Dungeon \& Dragons, perguntando à comunidade se havia quem concordasse a respeito da excessiva feminilização do RPG (Role Playing Game), notada por ele no fato de haver diversas imagens, nos livros de jogo, com mulheres magras e atraentes lutando contra dragões. Segundo Razor 007, embora sejam um colírio, figuras como essa são extremamente irrealistas, mas não pelos dragões, e sim por não fazer sentido que mulheres possam lutar contra eles; a "cereja do bolo" aparece já no título, em que o autor pede respeito à sua inquietação..$^{53}$

Por mais absurdo que pareça, o caso não é isolado, como nos mostra a GamerGate, movimento machista que assedia pesquisadores e desenvolvedoras via internet. Seus membros alegam ter como objetivo denunciar a corrupção do jornalismo sobre games, colocado em xeque após o site Kotaku publicar análises positivas do jogo Depression Quest, criado pela desenvolvedora independente Zoë Quinn. A hashtag \#gamergate (em referência ao caso Watergate) passou a ser utilizada em agosto de 2014, após o ex-namorado de Zoë, Eron Gjoni, acusá-la em seu blog de manter um relacionamento com Nathan Grayson, jornalista do site Kotaku; Zoë recebeu diversas ameaças, incluindo de estupro, e o caso ganhou proporções absurdas que repercutem até os dias de hoje.

Após essa polêmica, descobriu-se que Nathan nunca escrevera crítica alguma sobre Depression Quest e que o relacionamento dos dois começou após a avaliação ter sido publicada pelo site. Essas informações não impediram que as ameaças continuassem e fossem ampliadas, passando a outras desenvolvedoras, como Brianna $\mathrm{Wu}$, e a acadêmicas e jornalistas feministas, como Anita Sarkeesian; a partir disso, a GamerGate tornou-se um termo geral para a cruzada contra "ideologia de gênero" e respectful-about-this) (Acesso em Julho de 2019). 
"apoio a minorias", de modo a "defender" os jogos digitais da má influência dos "guerreiros da justiça social" (Social Justice Warriors) - que, segundo eles, têm por objetivo acabar com a criatividade e os bons produtos da comunidade geek. ${ }^{54}$

Desde então, esse movimento tem sido utilizado como exemplo de luta territorial por hegemonia no meio digital, e tornou-se tema de diversas pesquisas. Dentre elas, está o painel de Berendt et al. (2016), que aponta uma relação estreita entre (neo)liberalismo e a GamerGate, demonstrada por uma análise quantitativa e qualitativa de postagens na internet, cruzando a hashtag \#gamergate com um glossário de termos comuns do discurso (neo)liberal. A semelhança entre esse caso e os discursos de supremacia branca/europeia apresentados aqui a partir do trabalho de Alcoff (2006) nos parece evidente, e reforça nosso argumento de territorialização do ciberespaço, que segue padrões e um desenvolvimento comparável, mutatis mutandis, ao de espaços analógicos.

A situação de opressão generalizada é bastante conhecida e a necessidade de se posicionar a respeito do tema é ponto pacífico, como demonstram não só as diversas pesquisas em torno de gênero e sexualidade no meio digital, mas também a resposta da mídia especializada. Há, no entanto, uma espécie de incongruência entre as abordagens ludológicas mais proeminentes e as linhas de estudo que abordam esses problemas: enquanto estas não investigam a constituição estrutural do jogo como sistema semiótico, trabalhando prioritariamente com as manifestações de superfície - o que não consegue explicar como as opressões persistem mesmo quando o contexto parece ser favorável à diversidade -, aquelas focam exclusivamente na estrutura "neutra" ou na apropriação sem corpo de um espaço qualquer - o que termina por formar uma blindagem teórica para o jogo.

Nesta tese, buscamos preencher essa lacuna, aproximar as perspectivas e esboçar análises semióticoculturais de jogo, que dêem conta de trabalhar, ao mesmo tempo, com estruturas, manifestações e a circulação do jogo enquanto produto cultural industrializado e comercial. As linhas gerais dessa abordagem serão formuladas na próxima seção.

\footnotetext{
${ }^{54} \mathrm{O}$ site Wikipedia fornece um resumo mais detalhado da polêmica no link: https://en.wikipedia.org/wiki/Gamergate_controversy (Acesso em Julho de 2019).
} 


\section{O jogo como espaço semiótico e cultural}

Antes de prosseguir, retomaremos alguns conceitos já apresentados, para apontar de modo mais preciso quais lacunas nos propomos a preencher e, mais importante, por que é importante que essa "deficiência" teórica seja sanada. Para isso, discutiremos alguns jogos analógicos e esportes cuja complexidade ultrapassa de modo mais evidente as barreiras das abordagens previamente descritas. Concluída essa revisão, iniciaremos a discussão sobre a especificidade da variante digital, analisada na Segunda Parte.

\section{Por que tratar o jogo como espaço?}

Ao longo desta tese, trouxemos diversas definições de jogo que, embora não se neguem explicitamente, parecem ou inviabilizar umas às outras ou serem tão compartimentalizadas a ponto de uma camada possível de análise não dialogar com as demais. Sumariamente, podemos enquadrar as mais diversas abordagens nas seguintes vertentes:

1. Evento antropológico circunscrito a um espaço idílico;

2. Sistema de regras das quais derivam sentidos diversos;

3. Apropriação estética de espaço social;

4. Produto cultural que pode ser comercializado, semelhante a um livro ou filme; em suma, uma forma de Arte.

A distância entre elas é apenas artificial, uma vez que encarar um jogo como evento antropológico não significa que essa atividade seja desregrada ou que deixe de ser um produto; no entanto, o foco dado ao sistema abstrato de regras, que pode prescindir de materialidade, relega o evento a um plano secundário ou pode anulá-lo por completo, como aponta Sicart (2011) ao criticar ao modelo proceduralista.

$\mathrm{Na}$ prática de análise, a compartimentalização do jogo em diversos níveis de pertinência que prescindem ou negam a comunicação com os demais permite que uma abordagem crítica dirigida à construção de uma personagem, como, por exemplo, Senhorita Scarlet do famoso jogo de tabuleiro Clue (Anthony E. Pratt, 1949; publicado 
pelas empresas Waddingtons, Hasbro e Estrela) ${ }^{55}$, seja considerada como independente do funcionamento básico do jogo, visto apenas como um conjunto de regras que rege ações diversas (rolagem de dados, movimentação sobre o tabuleiro, interação entre as peças, possibilidades de palpites etc.). Nessa linha de análise, é mera coincidência ou acidente casual que essa personagem figurativize o tema da femme fatale, presente em diversas outras narrativas sobre assassinatos; assim como o fato de as personagens masculinas do jogo - Coronel Mustard, Reverendo Green e Professor Plum - serem caracterizadas por profissões/ocupações de prestígio social, enquanto as personagens femininas - Senhora Peacock, Senhora White, além da própria Senhorita Scarlet - ou representarem uma profissão considerada baixa (a Senhora White é governanta) ou não terem qualquer ocupação declarada (tanto a Senhorita Scarlet quanto a Senhora Peacock são "apenas" mulheres).

Efetivamente, não há diferença extrema entre jogar com um reverendo ou com uma velha interesseira - salvo a posição de início no tabuleiro e ordem de turnos -; no entanto, nos parece estranho, para dizer o mínimo, que uma estruturação sistêmica pretensamente neutra de uma história de assassinato gere figurativizações tão previsíveis, em termos de lugares comuns, na superfície discursiva e material do jogo. Para demonstrar esse ponto, comparemos duas edições especiais de Clue, as versões Os Simpsons e Star Wars.

Em The Simpsons Clue (2003), a temática e as regras se mantêm quase inalteradas: o jogo ainda se passa numa mansão, o enredo ainda envolve assassinato e a figurativização das personagens mantém quase a mesma simetria com o original, variando pouco - na primeira e na segunda edições da versão, as personagens

\footnotetext{
${ }^{55}$ Originalmente publicado no Brasil como Detetive, o jogo Clue coloca até seis jogadores em uma cena de crime, figurativizada como uma mansão; o objetivo é mover as peças pelo tabuleiro para entrar nos cômodos e dar palpites a respeito dos três aspectos do crime: o assassino, a arma utilizada e o local exato onde tudo ocorreu.

O mistério é renovado a cada partida por meio de um sistema de cartas: há seis suspeitos, seis armas e nove cômodos, que são embaralhados individualmente; após o processo, uma carta de cada monte é retirada com a face virada pra baixo e colocada em um envelope, depositado no centro do tabuleiro; em seguida as cartas são re-embaralhadas conjuntamente e distribuídas igualmente entre todos os jogadores (qualquer carta remanescente é separada e tem sua face revelada), que então iniciarão o jogo rolando o dado, movendo as peças e fazendo palpites para tentar descobrir quais cartas estão dentro do envelope; quando um jogador palpita, quem está à sua esquerda é obrigado a mostrar secretamente uma das cartas envolvidas na suposição; caso esse jogador não tenha nenhuma, o próximo em sentido horário deve fazêlo e assim por diante.

Em português, os nomes originais foram adaptados em Detetive: Senhorita Rosa (Miss Scarlet), Coronel Mostarda (Colonel Mustard), Dona Branca (Mrs. White), Senhor Marinho (Reverend Mr. Green), Dona Violeta (Mrs. Peacock) e Professor Black (Professor Plum).
} 
masculinas são transpostas ao mundo ficcional do desenho animado sem alterações de gênero, enquanto, no caso das femininas, a governanta é substituída pelo assistente gay do milionário Sr. Burns, Waylon Smithers, Jr.; na terceira edição, quem assume o papel da governanta é Marge Simpson, que representava a Sra. Peacock nas demais edições. Trata-se, portanto, de uma variação majoritariamente figurativa e que preserva, em certa medida, até mesmo os estereótipos culturais da versão original. Entretanto, em Star Wars Clue (2016), a dinâmica do jogo é consideravelmente alterada: em vez de uma trama de assassinato, os jogadores encenam uma tentativa de fugir com os planos de Darth Vader, que deseja destruir mais um planeta com sua Estrela da Morte; escolhendo uma dentre seis personagens do filme Star Wars: Episódio IV - Uma Nova Esperança (George Lucas, 1977), os participantes movem suas peças por um tabuleiro tridimensional bastante diferente do que é visto nas versões original e Os Simpsons:
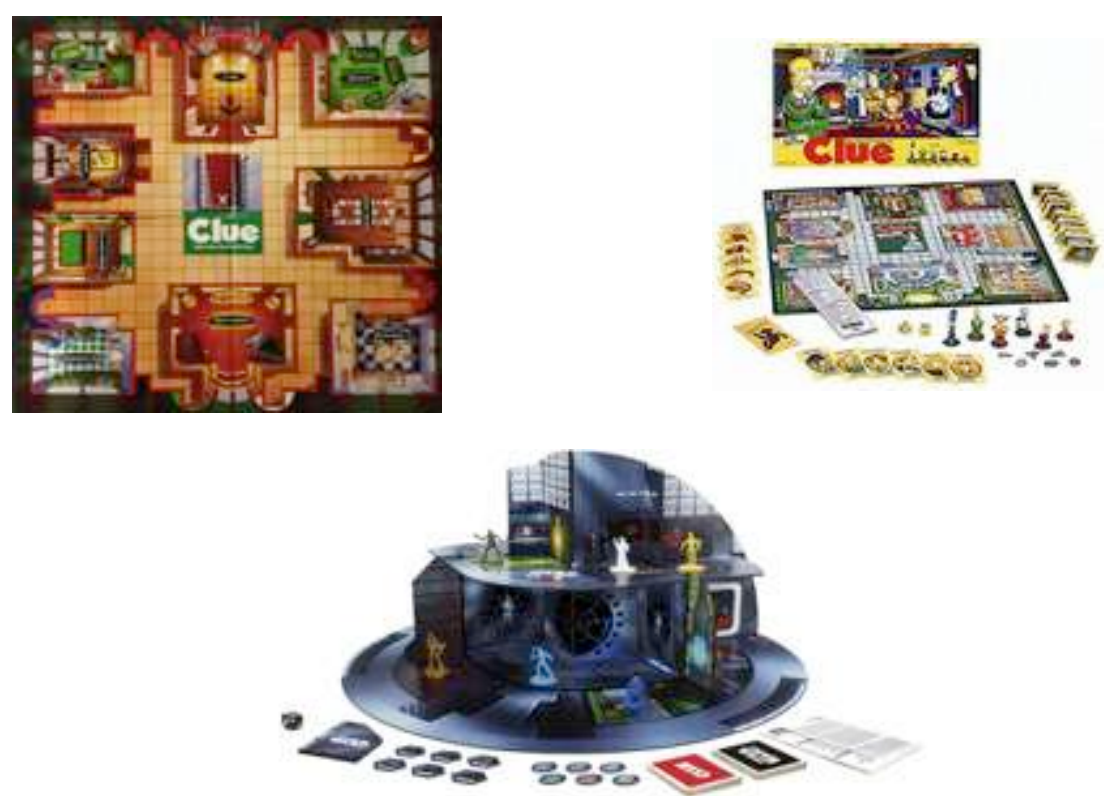

Imagem 1: Comparação entre tabuleiros de três versões de Clue (Google Imagens)

A disposição tridimensional afeta consideravelmente as regras de movimentação, que envolvem a compra de cartas caso o jogador não consiga entrar em nenhuma sala da Estrela da Morte para fazer seu palpite; dentre as possibilidades, há um intercomunicador - que permite ao jogador escolher um dos outros participantes e pedir que revele três informações (o local onde estão escondidos os planos, qual planeta será alvo de Darth Vader, e o veículo de fuga a ser utilizado pelo grupo) -, uma passagem livre para qualquer sala no mesmo andar, um deslocamento imediato ao depósito de lixo da 
nave e, a mais interessante das cartas, um Stormtrooper que prende o jogador em uma cela; caso seja capturado, o participante não poderá se mover pela Estrela da Morte em seu turno, devendo fazer todos os palpites a partir da cela - que é uma das salas possíveis no mistério. A única maneira de sair é sendo resgatado por outro membro do grupo; como recompensa, o jogador auxiliado deve mostrar uma de suas cartas ao seu salvador.

Essa regra é de especial relevância para o funcionamento do jogo na medida em que, diferente das versões original e Os Simpsons, não é possível fazer o palpite final que obriga o participante a conferir o resultado no envelope - a partir de qualquer sala: como não se trata de um mistério de assassinato e sim de uma investigação para estabelecer uma rota de fuga, é preciso que o participante vá para o hangar localizado no andar inferior do tabuleiro. Isso significa que, caso todos os jogadores sejam presos - o que é uma possibilidade permitida pelo conjunto de regras -, todos perdem: mesmo que a sala onde os planos estão seja descoberta antes da prisão, e os jogadores possam deduzir as demais partes da solução a partir da cela, ninguém poderá chegar ao hangar e fazer o palpite final. Essa modificação adiciona um componente cooperativo a um jogo que, nas outras versões, é puramente competitivo; caso os jogadores não cuidem uns dos outros e se resgatem, há uma chance de que todos percam.

A mudança temático-figurativa afeta, portanto, a constituição das regras no caso de Star Wars, o que pode ser compreendido, em nossa leitura, de duas formas: 1) a narrativa de fuga não faz sentido com as regras de movimentação originais - afinal, quem tenta espionar uma base inimiga não permanece à vista em corredores; e 2) a estrutura procedural do jogo não permite toda e qualquer configuração temático-figurativa. Isso fica mais evidente no caso Star Wars, mas também pode ser visto, de modo mais brando, em Os Simpsons, na medida em que as figuras adicionam um ar de comicidade que muda nossa percepção geral do tabuleiro, das personagens e da situação em geral, alterando nossa percepção das regras. Não se trata, portanto, do mesmo jogo.

Ainda nesse tópico, mesmo que a modificação explícita das regras de movimentação na versão Star Wars seja lida como pura estratégia comercial - uma configuração idêntica à do Clue original poderia não vender tão bem -, essa abordagem só demonstra que a estrutura do jogo não existe isoladamente, como um conjunto abstrato de procedimentos, mas é parte de um sistema mais complexo que envolve o reconhecimento do objeto enquanto produto. Nesse sentido, a utilização de Star Wars 
como tema geral viabiliza a comercialização em um nicho de mercado (o mundo geek), ao mesmo tempo em que foi selecionada especificamente para vender nesse nicho; some-se a isso a análise apresentada logo acima - as regras formatadas pela figurativização viabilizam o produto como novidade -, e também um possível contexto de utilização do produto: por exemplo, uma festa em que os convidados desejam um jogo mais cooperativo em vez de algo puramente competitivo pode direcionar a escolha da variante Star Wars dentre todas as versões de Clue - ou talvez Os Simpsons, devido à comicidade.

Seja como for, o modo como o Clue se apresenta no espaço determina maneiras pelas quais jogadores ocupam o espaço, no jogo ou em torno dele. Não se trata, no entanto, de um caminho unívoco e inexorável que exige a figurativização de uma personagem como a Senhorita Scarlet como femme fatale; o que nos interessa aqui é o fato de que essa via é efetivamente percorrida e, em grande parte, determinada por uma interação complexa entre todos os níveis de análise mencionados no início desta seção.

Um exemplo talvez mais contundente possa ser encontrado na análise da modalidade Olímpica de Ginástica Artística. Como diversos outros esportes, há uma divisão baseada em sexo biológico cuja justificativa reside na diferença hormonal entre corpos masculinos e femininos, da qual derivam limitações de força, velocidade, elasticidade etc., impossibilitando, assim, a competição justa entre pessoas de sexos diferentes. O curioso a respeito da Ginástica Artística é que, diferentemente do que ocorre com outros esportes, as modalidades masculinas e femininas são radicalmente diferentes: nas Olimpíadas de 2016, no Rio de Janeiro, participantes da primeira competiam em seis aparelhos - salto sobre a mesa, cavalo com alças, argolas, barras paralelas, barra fixa e solo -, enquanto os da segunda, em apenas quatro - salto sobre a mesa, trave, barras assimétricas e solo. ${ }^{56}$

À exceção do salto sobre a mesa, todos os outros aparelhos ou diferem absolutamente ou, especificamente no caso do solo, têm critérios de avaliação e execução distintas, que não se explicam diretamente pela diferença hormonal que, supostamente, dirige a divisão por sexos. Focando apenas as provas de solo, que fazem parte do quadro comum, verificamos que, enquanto a masculina tem por base a

56

https://pt.wikipedia.org/wiki/Gin\%C3\%A1stica_nos_Jogos_OI\%C3\%ADmpicos_de_Ver\%C3\%A3o_de_201 $\underline{6}$ (Acesso em Julho de 2019) 
exposição de força e destreza na execução de acrobacias, na modalidade feminina a graciosidade entra em cena: há música e uma coreografia geral que dirige a execução das acrobacias - passos de dança são, inclusive, parte integrante da pontuação.

Temos, portanto, uma divisão não necessariamente sexual, biológica, entre as modalidades, mas uma marca de gênero, que diz respeito não a limitações ou diferenças físico-fisiológicas, mas a modos de existência social; as regras, assim como no caso anterior, modificam-se para se adequar à desigualdade de gênero ao mesmo tempo em que as tornam possíveis e as propagam, perpetuando-as: um conjunto de critérios direcionado para exposição de força e destreza não é adequado para gerar figurativizações graciosas - compare-se com outro esporte, a Ginástica Rítmica, cuja modalidade masculina é recente e não é praticada por um número considerável de atletas para ser considerada Olímpica. ${ }^{57}$ Além disso, não há como desvincular a Ginástica Artística de outras práticas e sistemas semióticos, como o jornalismo esportivo, que frequentemente erotiza o corpo de atletas mulheres em suas publicações.

Diferenças sociais (não apenas de gênero) não são simplesmente comuns, mas constitutivas de esportes, sobretudo os que exigem acesso a equipamentos e a áreas trabalhadas especificamente para a modalidade, como é o caso de Golfe, do Hipismo e até mesmo da Natação. As variantes populares exigem adaptação e, muitas vezes, improvisações; nessa esteira, a originalidade e pureza das regras serve como forma de distinção social entre aqueles que podem e os que não podem praticar determinado esporte, aproximando o jogo de outros signos, como a etiqueta ${ }^{58}$ e a haute cuisine responsáveis por marcar, nas práticas alimentares, quem partilha de traços nobres, quem tem ou não sofisticação.

É nessa interação complexa entre regras, figurativizações, contextos sociais que entendemos aqui o jogo como forma de habitar espaços, de orientação e de disputa por territórios. Se regras fossem completamente descontextualizadas, imateriais e neutras, não haveria dificuldade alguma em minorias sociais se apropriarem de quaisquer espaços lúdicos; da mesma forma, a sua entrada em jogos não desencadearia ou requereria qualquer mudança nas regras. Assim como demonstrado por Ahmed (2006), qualquer invasão de território orientado para a exclusão causa desconforto e requer uma

\footnotetext{
${ }^{57}$ https://pt.wikipedia.org/wiki/Gin\%C3\%A1stica_r\%C3\%ADtmica (Acesso em Julho de 2019)

${ }_{58}$ Cf. CAILLOIS, 2000, p. 122. A etiqueta é, para Caillois, uma adoção do jogo imitativo na vida social.
} 
mudança estrutural, a qual, como demonstramos a partir de Alcoff (2006), gera uma reação do grupo hegemônico.

Se análises como a que fizemos acima das variantes de Clue parecem ter uma escala menor que a de exclusão de gênero, classe e/ou raça nos esportes, movimentos como a GamerGate reforçam nosso argumento. Defendemos aqui a ideia de que, apenas quando forem consideradas as relações complexas que mostram como os conjuntos procedurais dos jogos estão materializados em uma cultura em torno do jogo, determinando-a, ao mesmo tempo em que são formados por ela, teremos ferramentas analíticas adequadas para lidar com a exclusão social generalizada na cultura gamer, cuja discussão iniciaremos no próximo tópico.

\section{O jogo digital: semelhanças e contrastes}

Como demonstrado na seção 1 e reforçado algumas vezes ao longo do capítulo, espaços digitais podem ser analisados, semioticamente ao menos, com o mesmo instrumental teórico que espaços analógicos. No que diz respeito a jogos, essa afirmação requer um desenvolvimento maior, devido a algumas especificidades que a variante digital parece ter quando comparada à analógica, sendo a principal delas o fato de que as regras são aplicadas sozinhas pelo computador em vez de requererem um esforço coletivo de adesão e verificação - o video game dispõe de uma espécie de autogestão. Nossa abordagem demonstrará que mesmo nesse caso a adesão ou não dos jogadores à atividade ainda é central, podendo inclusive anular o controle da máquina e propor uma estruturação diversa - uma espécie de "sequestro"; nesse sentido, o critério de apropriação de espaço ainda se aplica, bem como as questões de orientação e identidade com as quais estamos trabalhando.

Retomando um exemplo já apresentado no início desta tese, uma situação de jogo ocorre quando há uma mudança de percepção e apreensão de espaço: ao andar por uma rua qualquer decidimos que a próxima esquina servirá como um ponto de referência ao qual devemos chegar, correndo ou pulando em uma perna só, num determinado limite de tempo; os elementos supracitados são ressignificados dentro do contexto criado pela afirmação dessas regras de conduta e o jogo se instaura pela apropriação do que era cotidiano e pela projeção de uma estrutura - essa é a definição de Sicart (2014), que 
complexificamos neste capítulo por meio de Ahmed (2006), Alcoff (2006) e da teoria semiótica. Jogos digitais funcionam de maneira muito parecida.

Ao possibilitar a apreensão dos dados computados pela máquina por meio de imagens e sons, o computador passou a constituir-se como um espaço, nos termos que definimos nesta tese: uma delimitação perceptível e modelada pela ação dos que nele habitam. A partir disso, o meio digital passou a ser construído, de modo mais e mais complexo, por um processo de "desbravamento", por uma conquista territorial de estabelecimento, desafio e expansão dos limites computacionais. O jogo digital, longe de ser fruto tardio dessa empreitada, é dela parte constituinte: nas décadas de 50 e 60, jogos foram desenvolvidos em laboratório para melhor compreensão de elementos importantíssimos em computação, como inteligência artificial, e também para teste de equipamentos; sendo um dos modos mais antigos e privilegiados de aproximação do mundo, como apontam Huizinga (1949) e Crawford (1997), o jogo reiterou seu estatuto ao converter-se em peça-chave na modelagem do que hoje chamamos de ciberespaço, como afirma Murray (1997) ao expor seu conceito de agência: "quando migramos a narrativa para o computador, o fazemos em um reino já moldado pela estrutura dos jogos"59 (p. 127, realces nossos). Mesmo quando não estamos jogando, nossa utilização de computadores para assistir a vídeos no YouTube, para fazer pagamentos bancários via NetBanking ou mesmo para escrever teses em editores de texto se dá em um território mapeado em grande parte por jogos.

O casamento fortuito entre o lúdico e o ciberespaço se dá, como Murray (Idem, passim) aponta, pela semelhança estrutural entre eles: ambos funcionam de maneira procedural - o que é uma dos motivos pelos quais essa perspectiva formalista recebe tanto destaque em ludologia. Seja como for, os jogos que compramos e aproveitamos atualmente em nossos consoles ou PCs são ao mesmo tempo motor e produto de um longo processo de formação do meio digital; em termos mais gerais, a compra de um jogo é a aquisição não (apenas) de um objeto físico, mas de uma proposta de habitação do mundo - seja analógico ou digital.

Em outras palavras, ao abrir um software de jogo em um console, um território se apresenta à percepção, configurado a partir de uma perspectiva que lhe confere organização e ordem, e que vai tentar orientar nossa ação, restringindo possibilidades ao

\footnotetext{
59 "when we move narrative to the computer, we move it to a realm already shaped by the structure of games."
} 
mesmo tempo em que apresenta outras. As semelhanças com a discussão de Ahmed (2006) não são coincidências, sobretudo à luz do que foi discutido no tópico anterior: jogos - e esse é o ponto central desta tese - são um dos mecanismos de orientação de sujeitos; a especificidade da variedade digital reside, em nossa perspectiva, quase que exclusivamente em uma mudança topológica: do mundo natural, passamos ao domínio eletrônico.

Sendo uma tentativa de nos orientar - em termos de semiótica narrativa, uma manipulação - o jogo digital está aberto, em certa medida, a reações, desvios e nãoconformidades; nos termos de Ahmed, podemos desorientar a proposta lúdica do ciberespaço, propondo uma nova organização e uma nova forma de habitá-lo. Exemplos disso são as mais diversas utilizações de softwares de jogo para pura exploração do ambiente tridimensional modelado: os títulos da série Grand Theft Auto (Rockstar Games, várias datas) e Red Dead Redemption (Rockstar Games, 2010) são comumente vistos como "alívio de estresse", em que o usuário ignora todas tentativas do software de impor qualquer linearidade ou finalidade às suas ações; nesses casos, a estrutura de procedimentos lúdicos se perde diante da arquitetura geral do ambiente, na medida em que o usuário impõe uma nova orientação aos objetos com os quais se depara, fazendo uso da física simulada de acordo com os seus próprios interesses, e não com a proposta "original" do software.

Qualquer jogo pode ser apropriado dessa maneira, embora softwares mais fechados tenham mecanismos mais severos de controle, sancionando rápida e negativamente os desvios do jogador e impedindo a continuação da atividade; isso não difere, no entanto, do que ocorre em um jogo analógico quando as peças de um tabuleiro são utilizadas de modo diferente do previsto pelo livro de regras, ou quando um baralho é utilizado para a construção de um castelo. Um conjunto de elementos designado especificamente para um jogo é, reforçamos, uma proposta que depende da adesão; em maior ou menor grau, intervenções inesperadas são, ironicamente, o esperado - trata-se do conceito de emergência, bastante difundido em ludologia, que diz respeito ao fato de um conjunto de regras poder gerar efeitos imprevistos pelos desenvolvedores do sistema quando este é colocado em movimento e suas partes passarem a se relacionar umas com as outras - muito embora, como aponta o Groupe $\mu$ (2015, pp. 145-149) em sua análise do conceito, todo e qualquer efeito emergente já se encontra inscrito no sistema; a imprevisibilidade é, portanto, uma limitação de nossa percepção. 
O fato de o evento proposto não ocorrer quando as regras são sumariamente ignoradas pelo usuário não invalida o fato de que a apropriação do espaço, digital ou analógico, efetivamente ocorre, e demonstra a fragilidade do lúdico: a adesão voluntária ao sistema pressupõe um esforço de conservação e controle, seja por parte de um árbitro esportivo, um grupo de amigos que entra em um acordo tácito de civilidade, ou um programa de computador que recebe inputs e responde com outputs diversos - o fato de que o software sanciona negativamente qualquer desvio só confirma a possibilidade de desviar. Um sistema muito fechado, por meio da iteração das punições ou da impossibilidade de divertir o jogador fora das regras previstas, será rapidamente abandonado caso o intuito da atividade não seja efetivamente testar os limites da proposta lúdica. Em softwares mais abertos, como é o caso de diversos jogos online, a não adesão não costuma gerar sanções negativas que inviabilizem a apropriação por parte dos usuários que tentam habitar aquele espaço por meio de orientações divergentes; essa característica gera, em nossa leitura, a coexistência de diferentes jogos dentro de um mesmo espaço, derivados das ações recorrentes de grupos de jogadores diversos.

A coabitação de orientações, no entanto, como vimos nos estudos de Ahmed (2006) e Alcoff (2006), gera conflitos e uma disputa por hegemonia, característicos da constituição semiótica de territórios, como apontamos com base em Fontanille (2015). É a partir desse embate entre diferentes formas de ser e de jogar que surgem os conflitos centrais para esta tese, os quais serão demonstrados nas análises da Segunda Parte. 


\section{Estereótipos, figurativização e mecânicas de jogo:}

\section{uma isotopia restritiva}

Na Primeira Parte desenvolvemos as bases que norteiam nossa crítica tanto às abordagens procedurais quanto às que focam meramente no jogar e seus desdobramentos sociais. Demonstramos brevemente, por meio de jogos analógicos e de esportes, como as restrições feitas ao corpo no espaço lúdico vão desde as bases mais formais da atividade - o conjunto de regras -, passando por figurativizações as mais diversas - vestimentas, desenvolvimento do projeto gráfico do tabuleiro - e chegam às interações intersubjetivas entre jogadores até mesmo fora dos limites do "círculo mágico" de Huizinga - comentários às performances de homens e mulheres na mídia, foruns de discussão online.

Todos esses "níveis" de pertinência distintos são, em realidade, retroalimentativos, e um não consegue existir sem o outro: no caso da ginástica, analisada brevemente, as diferentes regras das modalidades masculina e feminina criam as variações de performance de atletas e, ao mesmo tempo, são confirmadas por tipos de vestimenta que delimitam papeis de gênero; estes, socialmente determinados, também limitam as escolhas de vestuário e exigem, por sua vez, que as regras em si sejam diferentes.

A análise do fenômeno lúdico, portanto, não pode concentrar-se ou nas regras ou no jogar enquanto atividade social, tendo em vista que o problema que nos dispusemos a investigar nesta tese não se encontra nem em pólo, nem em outro, mas na interação complexa entre jogo, jogar e mundo que ocorre no corpo - o qual caracterizamos, baseando-nos tanto em teorias ludológicas e semióticas, como sede do lúdico enquanto forma de habitar o mundo.

Ao tratar brevemente da questão da questão do espaço digital, demonstramos que este pode ser analisado da mesma maneira que o mundo natural. Sendo assim, partiremos do princípio de que o ciberespaço, aparentemente democrático, não 
possibilita acesso e apropriação homogênea de suas mais diversas ferramentas, as quais são disponibilizadas ou negadas de acordo com uma hierarquia latente - e, justamente por isso, perniciosa - que mimetiza a organização social do mundo não-digital. Há usuários com mais voz e mais direito a voz que outros, porém quem controla a concessão da palavra não se encontra localizado em ponto algum - todos e ninguém ao mesmo tempo contribuem, ativa ou passivamente, para a manutenção dessa hierarquia.

Como forma de complementar essas discussões, o objetivo deste capítulo é analisar em maior detalhe o funcionamento dessa hierarquia em jogos digitais, demonstrando que há um direcionamento corporal, ao mesmo tempo latente e manifesto, baseado no princípio de negação e marginalização de tudo aquilo que não atende aos padrões do topo da hierarquia: o estereótipo masculino, heterossexual, e localizado no centro da sociedade colonizada em que vivemos. Dito de outro modo, trata-se de demonstrar que jogos digitais são feitos sob medida em todos os seus aspectos - desde as mecânicas mais básicas até sua socialização - para um único grupo social, enquanto os demais são marginalizados - seja por exclusão enquanto mercado consumidor ou por representação figurativa estereotipada sob o ponto de vista do grupo dominante.

Inicialmente, o foco será dado a jogos offline, os quais podem ser jogados de modo solitário e sem contato obrigatório com outros jogadores ou com a comunidade gamer. Demonstraremos que mesmo nos casos em que o jogador não se encontra obrigatoriamente conectado com outros e poderia, em tese, fazer uso do sistema como bem entender, há um direcionamento corporal que impede a apropriação livre do jogo e que determina o modo como o software do jogo será utilizado. Desvios que não estão de acordo com a hierarquização são, frequentemente, sancionados negativamente de diversas maneiras e, muitas vezes, impedem que o jogador atinja a vitória.

Como corpus de análise nos limitaremos a quatro jogos. Os dois primeiros são mais antigos, pertencentes ao gênero RPG: Final Fantasy IX (Squaresoft, 2000) e Final Fantasy X (Squaresoft, 2001). A escolha dos títulos teve como critério sua popularidade no meio digital e a variedade mecânica de título a título; há inovações técnicas no que diz respeito às mecânicas de jogo e uma tentativa de se desvincular de alguns tropos narrativos, porém demonstraremos que as hierarquizações sociais comentadas até o momento nesta Tese reduzem, em grande medida, a eficácia dessa variedade e 
aproximam os títulos que, à primeira vista, parecem tão distintos - trata-se, em suma, de uma diferença superficial que, em vez de negar, confirma a regra.

Após a consideração desses dois títulos, ambos jogados offline, partiremos para o comentário de dois jogos bastante dominantes no cenário online atual: Overwatch (Blizzard, 2016-presente) e League of Legends (Riot Games, 2009-presente), os quais constroem-se a partir de elementos discursivos consolidados nos jogos de RPG mais antigos - dos quais Final Fantasy IX e Final Fantasy $X$ são exemplos.

No entanto, antes de iniciarmos o comentário específico dos jogos, é importante esclarecer algumas questões acerca do gênero focado e elucidar um pouco do vocabulário a ser utilizado ao longo do texto. Esse será o assunto da primeira seção desta parte.

\section{O que é um RPG?}

Em sua forma mais básica, o RPG (Role Playing Game) de mesa cobre um tipo de jogo que tem como foco a interpretação de papeis com o objetivo de desenvolver um enredo narrativo do início ao fim. RPGs analógicos são organizados em torno de um Mestre (Dungeon Master) que irá coordenar a aventura e diversos jogadores que representarão cada personagem. Cada jogador tem seu turno e pode desempenhar ações cujo grau de liberdade varia de acordo com cada jogo; geralmente, o critério máximo é a coerência com o universo de valores determinado ou com detalhes previamente combinados - por exemplo, de acordo com a mitologia corrente, um vampiro não pode sair no sol ou invadir uma casa sem ser convidado, a menos que isso seja determinado como possível naquela sessão.

Há, porém, restrições mecânicas ligadas às regras de funcionamento do jogo: personagens, em geral, pertencem a determinadas classes com habilidades prédefinidas. Guerreiros, Arqueiros, Magos, Ladinos, cada qual com um papel narrativo a desempenhar e que restringem a ação - um Mago não é capaz de quebrar com as mãos uma porta de madeira muito pesada pois seus atributos de Força e Vitalidade são baixos, porém ele teria a opção de queimá-la com uma magia de fogo ou derrubá-la de algum modo valendo-se de algo descrito como parte do cenário. 

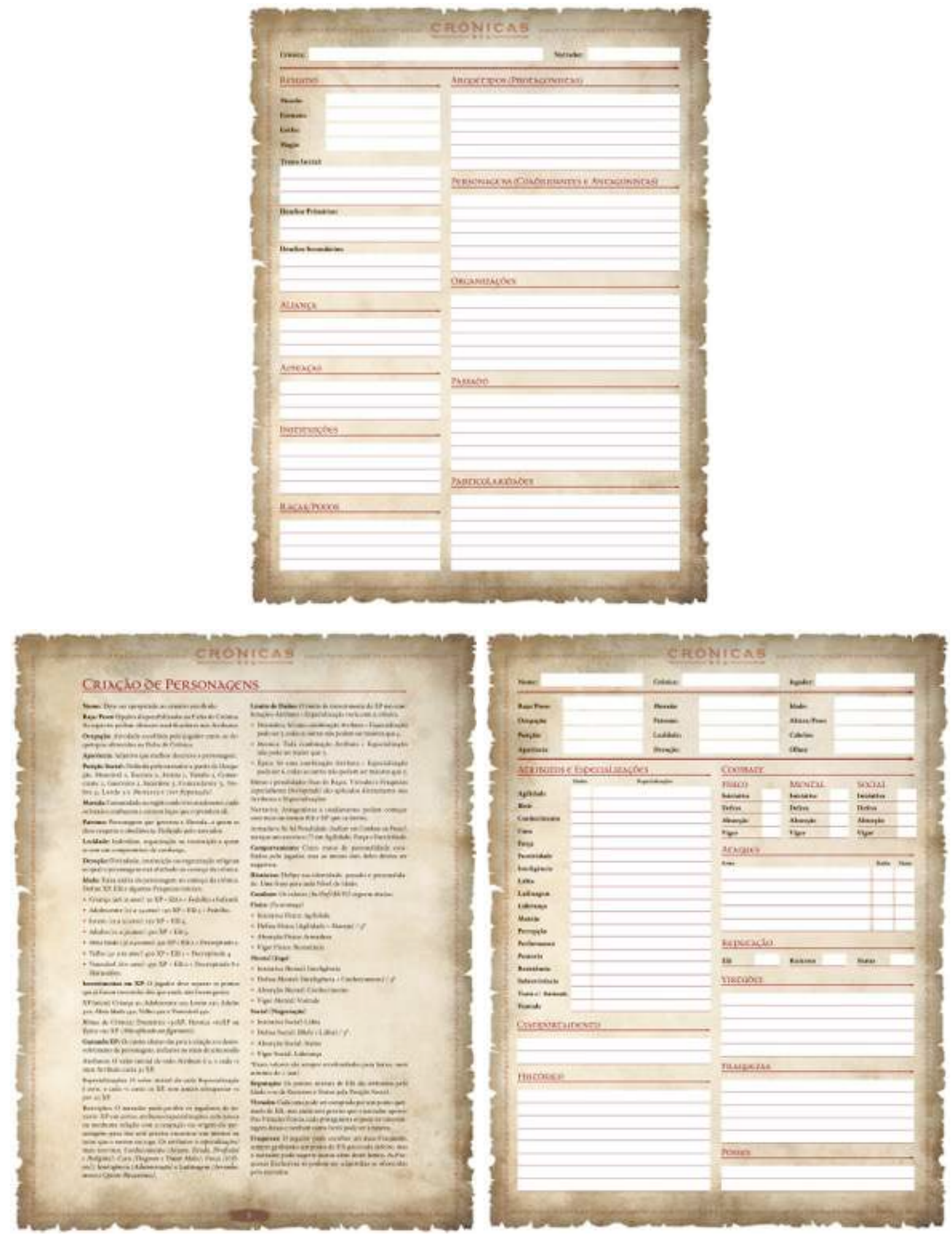

Imagem 2: Fichas de jogo, personagem e explicações básicas do RPG Crônicas ${ }^{60}$

Essas restrições mecânicas constituem o cerne do RPG, sua jogabilidade (gameplay): ser um Ladino implica agir como um Ladino, desempenhar esse papel de

${ }^{60}$ Disponível em: http://cronicasrpg.com.br/?page_id=1787 (Acesso em Julho de 2019) 
acordo com os limites. Mesmo quando não há classes rotuladas, cada personagem em uma sessão de RPG terá sua jogabilidade pré-determinada por limites fixos que direcionam o jogador e estabelecem o que pode ou não ser feito. Em suma, a jogabilidade restringe o corpo do jogador e o guia pelo espaço lúdico. É este o aspecto dos RPGs que mais nos interessa e que justifica a escolha do gênero como foco de nosso corpus.

\section{A variedade digital do RPG}

A versão digital de jogos de RPG retém diversos aspectos da jogabilidade do RPG analógico, exceto evidentemente sua coletividade e oralidade inerentes. O que caracteriza o RPG digital é, em suma, o fato de que o jogador, ao seguir pelo jogo, encontra-se restrito em seu corpo pelos limites de classe da(s) personagem(ns) que controla. Em alguns casos, cria-se uma personagem com determinados atributos e escolhe-se uma classe para jogar; em outros, há diversas personagens controladas pelo jogador, cada qual com uma classe específica. Seja como for, as restrições existem e faz parte do desafio imposto pelo jogo a utilização adequada de cada classe para vencer os obstáculos e fazer com que a narrativa se desenvolva: derrotar um monstro, explorar uma caverna do início ao fim, escapar de um calabouço - essas tarefas, ao concluídas, permitem ao jogador a exploração de novas áreas e, consequentemente, o acesso a novos conteúdos narrativos. 


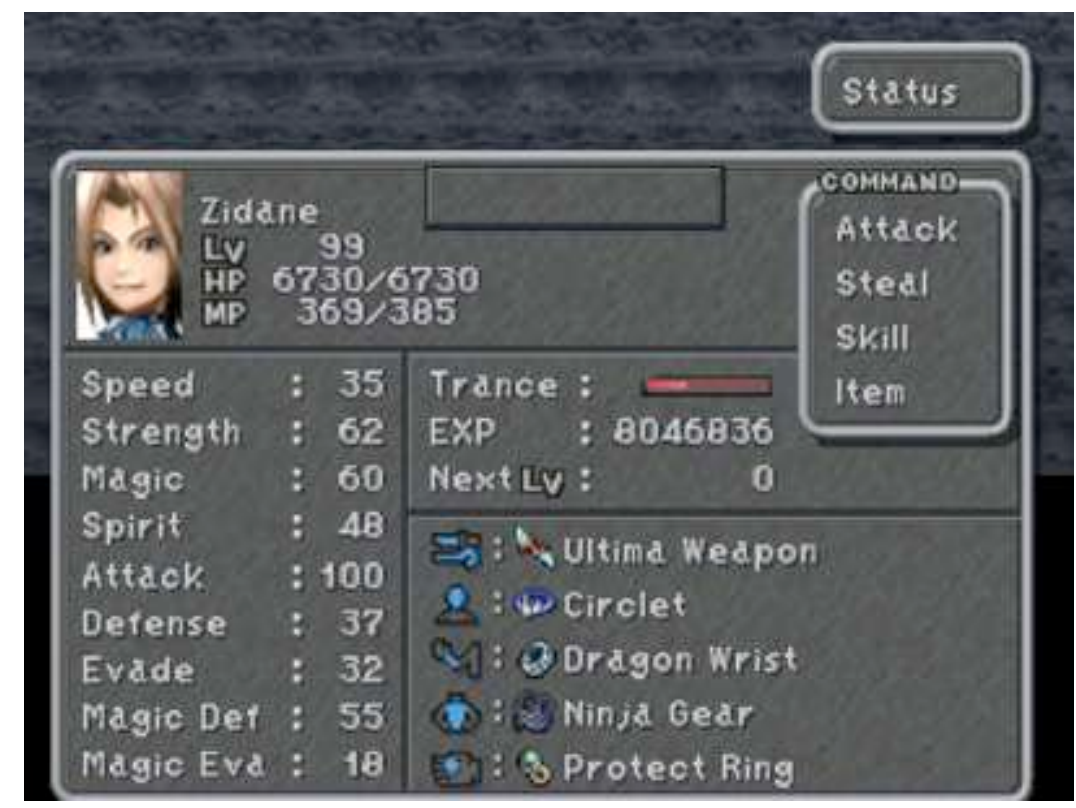

Imagem 3: Tela de atributos de Final Fantasy IX (Captura de tela)

Há, em um primeiro olhar, bastante liberdade no que diz respeito à jogabilidade: podendo escolher dentre diversas classes ou manusear um conjunto de personagens com habilidades distintas, cabe ao jogador formar sua estratégia pessoal, valendo-se da aparente diversidade para imprimir personalidade e individualidade ao jogo - alguém que escolhe jogar como Ladino terá uma experiência diferente de quem escolhe jogar como Mago. No entanto, muito embora essas decisões existam de fato e haja bastante espaço para que cada jogador se mova dentro dos limites propostos pelo jogo, o peso de cada escolha não é o mesmo.

A depender do jogo, é muito comum que determinadas escolhas criem problemas ao jogador e aumentem artificialmente o nível de dificuldade das missões. Apesar de muitas vezes isso ser intencional e jogadores decidirem conscientemente fazer com que o jogo fique mais desafiador, o que nos interessa é que os limites impostos a cada estratégia sejam inerentemente diferentes e alterem a mobilidade dos corpos no espaço lúdico.

Como nos exemplos analisados anteriormente, essas diferenças de jogabilidade e seus respectivos pesos no que diz respeito à dificuldade do jogo são acompanhadas de variações figurativas as mais diversas e de dispositivos narrativos que muitas vezes marginalizam determinadas personagens, representando-as de acordo com estereótipos altamente questionáveis. É essa intersecção de orientações que nos interessa prioritariamente neste momento: como variações mecânicas ao mesmo tempo refletem e 
são refletidas em representações figurativo-narrativas em RPGs analógicos, e de que modo isso cria novas restrições corporais aos jogadores.

\section{Theorycrafting e metajogo}

Antes de prosseguirmos, é importante desenvolver o motivo pelo qual RPGs são tão propensos a criar dificuldade artificial por meio de diferenças de performance entre as estratégias. Embora tenhamos citado apenas alguns exemplos, RPGs - sobretudo digitais - tendem a apresentar uma quantidade enorme de classes e ações disponíveis para seus jogadores.

Ter acesso a uma lista vasta pode ser bastante exaustivo em uma primeira abordagem, e muitas vezes não é possível fazer uso de tudo o que o jogo apresenta com a mesma frequência ou intensidade; em alguns casos, o jogador sequer pode acessar tudo em uma mesma sessão de jogo: é preciso treinar personagens e, ao atingir níveis pré-determinados, escolhas são impostas - por exemplo, uma personagem que escolha jogar como Ladino em um dado momento talvez tenha de optar por desenvolver habilidades com arco e flecha ou adagas, mas não poderá utilizar ambas as armas. Mesmo que possa, diversos jogos programam seus combates por meio de turnos, permitindo ao jogador utilizar apenas uma habilidade por vez, mesmo que várias delas estejam disponíveis; o campo de ação é, portanto, sempre bastante limitado e escolhas são impostas.

No caso de jogos de RPG com múltiplas personagens, as restrições também afetam a quantidade que poderá ser utilizada em combate; grupos (de três a cinco, geralmente) precisam ser formados, e consequentemente nem todas as classes ou ações estarão disponíveis ao mesmo tempo. Fora isso, há também questões de equipamentos e atributos: determinadas classes podem vestir roupas de couro ou armaduras leves, cada qual com atributos (força, destreza, vitalidade) diferentes. Normalmente, nem a composição de grupo ou os equipamentos podem ser alterados durante combates, 0 que impõe uma decisão um tanto quanto determinante, tendo em vista que as escolhas limitarão as estratégias possíveis e não poderão ser desfeitas a não ser que a sessão de jogo seja reiniciada. 

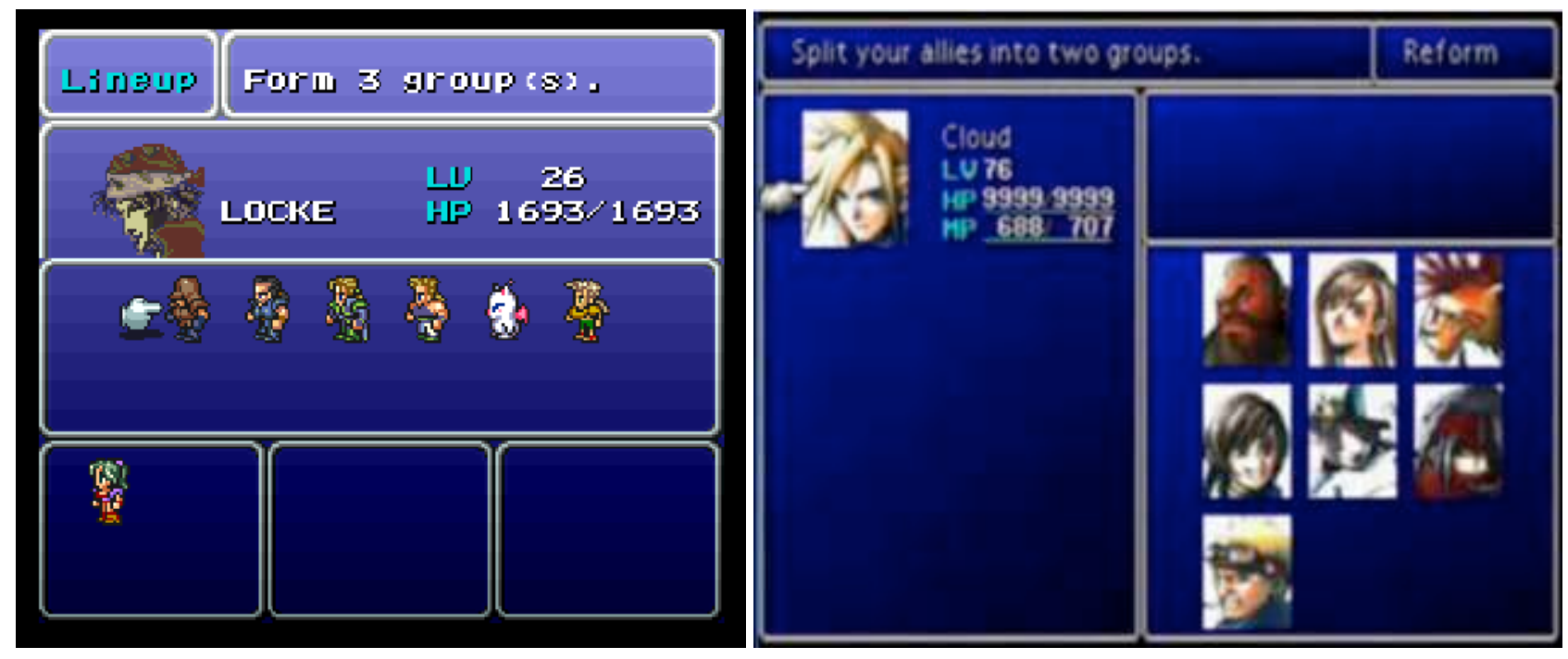

Imagem 4: Menus de formação de grupo em Final Fantasy VI e Final Fantasy VII (Captura de tela)

Essa característica inerente do gênero RPG faz com que jogadores dediquem bastante tempo ponderando acerca das estratégias de composição de grupo ou desenvolvimento das personagens; muitas vezes, testes com método são feitos e resultados registrados - por exemplo, um jogador pode questionar se feitiços de fogo são mais poderosos do que feitiços de trovão, ou querer determinar com precisão em que condições um feitiço de atordoamento é capaz de atingir certos inimigos. Essa prática é chamada pela comunidade de jogadores de theorycrafting e representa um dos pontos mais interessantes dos jogos digitais; trata-se, sob nosso ponto de vista, de uma atividade crítica, comparável à análise de poemas ou pinturas, em que se tenta desmembrar e entender quais são as características mais detalhadas do sistema de restrições e limites propostos por um jogo. Uma vez que consideramos jogos como limitações de movimentação de corpos no espaço, conhecer o teor dessas limitações é justamente o que permite ao jogador mover-se criticamente, entender o que está ali proposto - ideologicamente, inclusive. 


\begin{tabular}{|c|c|c|c|c|c|c|c|c|c|c|c|c|c|c|c|c|}
\hline & 4 & & 3 & c & in & \pm & $t$ & 3 & II & 1 & 1 & $*$ & L & $M$ & N & 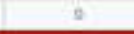 \\
\hline 1 & $N$ & & तT & $n$ & anth & Gation pount & DET & u & on & Entore pulnt & cerr & Rath & cound & $u$ & and & Gan per Polt \\
\hline 2 & & $\omega 0$ & & a,s & m & $\infty$ & 282 & t & 0.00000 & 0.00600 & se & 10.05 & 14 & 102 & 000000 & $0,0000 \mathrm{n}$ \\
\hline 3 & & 636 & & 0.02 & 10000000 & ก..3หn & 20 & 1091 & 0.96000 & 0.0059 & 235 & 0.055 & 1.481 & 1.05045? & 0.0425 & $0.0002 \pi$ \\
\hline * & & es : & & 0,00 & so 000094 & $25.0000 \mathrm{n}$ & 28 & 1.092 & $00400 \mathrm{~s}$ & 0.02554 & at & 0.052 & 1.492 & 1.000054 & 00448 & D.000/ \\
\hline 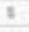 & & 670 & & 0.04 & 3323035 & 16.66 & 301 & 1003 & 0.0958 & 0.0055 & $3 n$ & 0.053 & 1.403 & 1.021350 & 0.0445 & 0.00412 \\
\hline * & & s? & $n$ & 0.05 & $250000 x$ & $12.5600 \mathrm{~s}$ & 254 & 1024 & Q.0\%5 & $0.00 \mathrm{es}$ & sat & 10.054 & 3.434 & 1.021816 & 0.0483 & Detors \\
\hline 7 & & $7 \pi$ & $n$ & 0.06 & $20 \cos x$ & 10.900001 & 20 & 1005 & $0.0506 x$ & 0.0055 & as & $0.05 s$ & 1.458 & 1.002025 & 0.0645s & 0.60418 \\
\hline 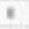 & & $n 7$ & 75 & 0.07 & $166667 \mathrm{x}$ & 83333 & mo & 1006 & 60005s & $\cos 5 x$ & so & 0.056 & 1,456 & 1.002736 & 0.04513 & Decosis \\
\hline ". & & 767 & & an & 1426573 & 4.76150 & 609 & 1087 & D.S500 & 0.00625 & $4 t$ & 0.057 & 1,458 & 1 t6rasiss & ocosss & Dooss \\
\hline in & & $78-8$ & & 0.09 & $12 \operatorname{secos} x$ & 6.25000 & est & 1028 & 0.04091 & 0.0058 & 45: & 0.058 & 1.458 & 1.023564 & 0.04543 & 0.00618 \\
\hline II & & to : & 2 & 0.1 & 11:mts & 5.55566 & 40 & 10006 & townst & 0.0055 & 42 & 0.059 & 1,450 & 1025131 & oosss & a.60015 \\
\hline 12 & & 50 & os & 0.11 & $10.0000 x$ & 3.3330 & 459 & 100 & 0.05918 & $0.0062 x$ & 4n & 1005 & 1.47 & 1.6245 & acossis & 0.00828 \\
\hline$\pi$ & & es: & 7 & 0.12 & 0.00005 & 4.54558 & as & 1011 & Daver & $0.005 x$ & 44 & 0.051 & 1411 & 1 tassen & 0.045: & 0.00025 \\
\hline 3 & & $n 8$ & & 0.13 & 833001 & 4.160 & $\omega$ & 1.912 & อง96\% & o.0osex & oss & 0.052 & 1.452 & 1.025544 & 0.0658 & 0.00425 \\
\hline$n$ & & no & & 0.4 & $8.6023 \pi$ & 256418 & 504 & 1.013 & o.ouess & $0.0062 \pi$ & 525 & 60.053 & 1443 & 1.606010 & 0.04537 & $0.0062 t$ \\
\hline * & & 92 & & a.15 & 7.16095 & 357148 & 525 & 1094 & 0.04En & 0.0054 & 516 & 10.084 & IAT & 1.026486 & 0.0055 & o.toess \\
\hline 77 & & 90 & & 0.16 & 6.666n & 3.33334 & ses & 1015 & $0.0986 \mathrm{~V}$ & o.00ses & 521 & 0.065 & 1.415 & 1.028975 & $0.0457 x$ & 0.0043 \\
\hline 11 & & n) & n & o.n & 62500 & $2003 x$ & we & 1016 & D.6963s & 0.0058 & sat & 1000 & 1416 & 1.027456 & Q o esestix & 0.00005 \\
\hline v & & 91 & 101 & 2.18 & 5.88251 & 294122 & 376 & I & Doses & $0.0012 x$ & 569 & 0.057 & 1417 & $1.02 \times 3915$ & 0.0478 & Detosin \\
\hline
\end{tabular}

Imagem 5: Reprodução de tabela comparativa de atributos secundários do jogo Final Fantasy XIV à época da expansão Stormblood ${ }^{61}$

Os resultados obtidos a partir dos testes e cálculos feitos pelos jogadores são, então, comparados de modo a verificar as diferenças entre cada elemento que compõe o sistema; com grande frequência - para não dizer sempre -, uma determinada amostra apresenta resultados mais consistentes ou numericamente mais vantajosos para a execução de determinada tarefa - por exemplo, atacar um inimigo utilizando uma magia de fogo ou uma de gelo, ou então atacar usando magias quaisquer que sejam ou com uma espada. Há, portanto, um certo tipo de "solução" para jogos de RPG, um conjunto de estratégias ou combinações de atributos e itens que é matematicamente superior aos demais no que diz respeito à eficácia; ou seja, muito embora o jogo possibilite múltiplas estratégias, uma será, do ponto de vista sistêmico, melhor. É o que chamamos de metajogo ou simplesmente meta.

Embora seguir o meta seja, evidentemente, opcional - estamos lidando com jogos comprados ou alugados por cada jogador, que irão usufruí-los individualmente -, ignorar a opção matematicamente superior aumenta artificialmente a dificuldade do jogo; em casos extremos, afastar-se demasiadamente do meta pode impossibilitar a vitória. É nesse sentido que as escolhas entre classes ou estratégias mencionadas no item anterior restringem o corpo.

Outra questão a respeito do meta é a troca de informações entre jogadores tender a ocorrer mesmo que os jogos sejam offline. Revistas especializadas, websites, foruns gerais de discussão: todos esses meios de comunicação são utilizados para que

\footnotetext{
${ }^{61}$ Disponível em: https://www.reddit.com/r/ffxiv/comments/6nzdnd/level_70_secondary_stats_compared/ (Acesso em Julho de 2019)
} 
jogadores debatam suas estratégias e construam, coletivamente, o meta. Não se trata apenas de jogar um jogo qualquer, mas de jogá-lo bem: há um aspecto, senão competitivo, ao menos social no que toca à qualidade, eficiência ou elegância do ato de jogar; quando a vitória já é garantida, um dos atrativos de um jogo - sua condição de replay - é vencê-lo novamente com melhores resultados.

O afastamento do meta - seja por vontade própria ou involuntariamente (sentir-se desconfortável ou ser discriminado por suas escolhas) - é uma forma de isolamento em relação à comunidade e, consequentemente, também é uma forma de marginalização $e$ restrição do corpo. É, dito de outro modo, um ostracismo daqueles que não querem ou não estão aptos a seguir o meta, seja por quais motivos forem. Ser rotulado como "mau jogador" causa solidão.

Os jogos selecionados para análise neste capítulo são relevantes nesse aspecto uma vez que, por serem RPGs, estão sujeitos à prática do theorycrafting. Além disso, por terem sido lançados em uma época já avançada do desenvolvimento do meio ludodigital, geraram bastante debate na comunidade; tanto na mídia impressa quanto na internet é possível achar discussões a respeito do meta de cada jogo. por questão de conveniência e de interesse geral para a discussão aqui apresentada, nossos exemplos estão concentrados nas discussões que podem ser encontradas online. É importante ressaltar que, mesmo no caso de Final Fantasy IX, desenvolvido há quase duas décadas, a discussão a respeito do meta ainda prossegue, atingindo até mesmo novos jogadores que muitas vezes sequer haviam nascido na ocasião do lançamento.

\section{A série Final Fantasy}

Os RPGs escolhidos para o corpus pertencem à série Final Fantasy, e, para finalizar esta seção, é importante esclarecer alguns pontos a respeito desses jogos, e justificar a seleção deles na composição do corpus. Em primeiro lugar, muito embora sejam intitulados "Final Fantasy", os jogos desta série não são, necessariamente, sequenciais. Final Fantasy $I X$ e Final Fantasy $X$ possuem enredo, personagens e jogabilidade completamente distintas um do outro, além de serem desenvolvidos por equipes muito ou totalmente diferentes, constituindo-se, portanto, como títulos separados. Nesse sentido, o nome Final Fantasy seria melhor descrito como o rótulo de uma franquia. 
O que define o pertencimento - ou não - de um jogo a essa franquia é a recorrência de alguns nomes de personagens, feitiços e temáticas - por exemplo, a partir de Final Fantasy IV, é comum em jogos da série haver uma personagem chamada Cid que desempenha alguma função (central) no enredo ligada à aviação e/ou mecânica: em Final Fantasy VII (Squaresoft, 1997), Cid Highwind é uma das personagens controláveis pelo jogador, um cientista aeronáutico que sonha em levar um foguete à lua; em Final Fantasy XV (Square-Enix, 2016), Cid Sophiar é uma das personagens não-controláveis, um velho mecânico que comanda o posto de gasolina e mecânica de Hammerhead, e ajuda o jovem príncipe Noctis (a personagem principal) em sua jornada, seja construindo armamentos, seja auxiliando sua neta, Cindy, a aprimorar o veículo Regalia, utilizado pelo jogador para se locomover pelo jogo. Por esses motivos, Final Fantasy IX e Final Fantasy $X$ podem ser analisados como jogos completamente diferentes.

A seleção desses títulos da série para o corpus não foi aleatória. Ambos foram publicados no início da década passada (em 2000 e 2001, respectivamente), e representam um estado de "maturidade" do gênero em sua modalidade offline: há mecânicas de jogo consolidadas e que representam padrões não só da série, mas do gênero como um todo, e que posteriormente tornaram-se menos comuns na indústria em decorrência do surgimento e aprimoramento dos RPGs online - a possibilidade de jogar em rede alterou significativamente os jogos offline, cuja jogabilidade tornou-se (ainda) mais experimental.

Além disso, Final Fantasy IX e $X$ são os títulos offline da série mais recentes a adotar, em maior ou menor grau, o sistema de classes de personagens que comentamos ao longo deste capítulo; sendo esse sistema essencial para a hipótese desenvolvida nesta Tese - uma vez que os jogos online atuais fazem uso exaustivo dele - a escolha desses títulos se justifica.

\section{Final Fantasy IX}

Este jogo tem como centro uma trama política densa envolvendo os três reinos do Continente da Bruma - Alexandria, Lindblum e Burmecia -, um dos continentes do planeta Gaia. O jogador controla um grupo de personagens que, direta ou indiretamente, se veem implicadas nos planos de dominação da Rainha Brahne de Alexandria, iniciados após o aparecimento de um homem misterioso chamado Kuja. Para impedi-la de atingir 
seus objetivos, cada personagem terá de confrontar seu passado e seus temores, ao mesmo tempo em que desvendam os mistérios dos continentes perdidos de Gaia e descobrem o que há por trás das intenções de Kuja.

Analisar em detalhe cada ponto da trama de Final Fantasy IX requereria uma tese em si mesma, portanto limitaremos nossa abordagem a alguns pontos que consideramos essenciais para os objetivos de nosso trabalho, a saber: as diferenças básicas de jogabilidade entre personagens masculinas e femininas; a temática da "donzela em apuros"; e, por fim, as diferenças linguísticas e culturais entre os povos "avançados" do Continente da Bruma e os "primitivos" do Continente Exterior.

\section{O sistema de batalha}

Final Fantasy IX é o que poderíamos chamar de "RPG tradicional", e sua jogabilidade consiste basicamente na movimentação do grupo pelo cenário, indo de um ponto a outro até encontrar a via que leva à continuidade do enredo; o tempo narrativo, como é comum em jogos digitais, está atrelado à exploração do espaço - a história avança quando o caminho "correto" é percorrido. No que toca à movimentação, não há diferença alguma entre as personagens controladas; uma das personagens do grupo (geralmente Zidane ou a princesa Garnet) será visível e o grupo como um todo será por ela representado.

Eventualmente, combates ocorrerão enquanto o jogador explora o cenário; é o sistema de encontros aleatórios, em que os inimigos não são visíveis e o sistema do jogo gera batalhas randômicas com base em parâmetros pré-determinados. Quando isso ocorre, há uma transição cênica e a tela de batalha é exibida; nela, os inimigos aparecerão alinhados de um lado, e todas as personagens do grupo aparecerão alinhadas de outro e divididas em duas fileiras; o jogador poderá também visualizar dados relevantes para a batalha - a força vital, força mágica e barra de ATB (Active Time Battle) de cada personagem.

O sistema ATB, bastante utilizado na série Final Fantasy, consiste em uma pequena barra que é gradualmente preenchida; quando cheia, a personagem em questão poderá realizar uma ação dentre aquelas disponíveis para ela. $\mathrm{O}$ atributo de velocidade determina a rapidez em que a barra é preenchida, e caso mais de uma personagem possa agir ao mesmo tempo, o jogador poderá escolher qual agirá primeiro. 
Após a decisão ser tomada e a personagem executar o comando, a barra de ATB será esvaziada e o processo de preenchimento se reiniciará.

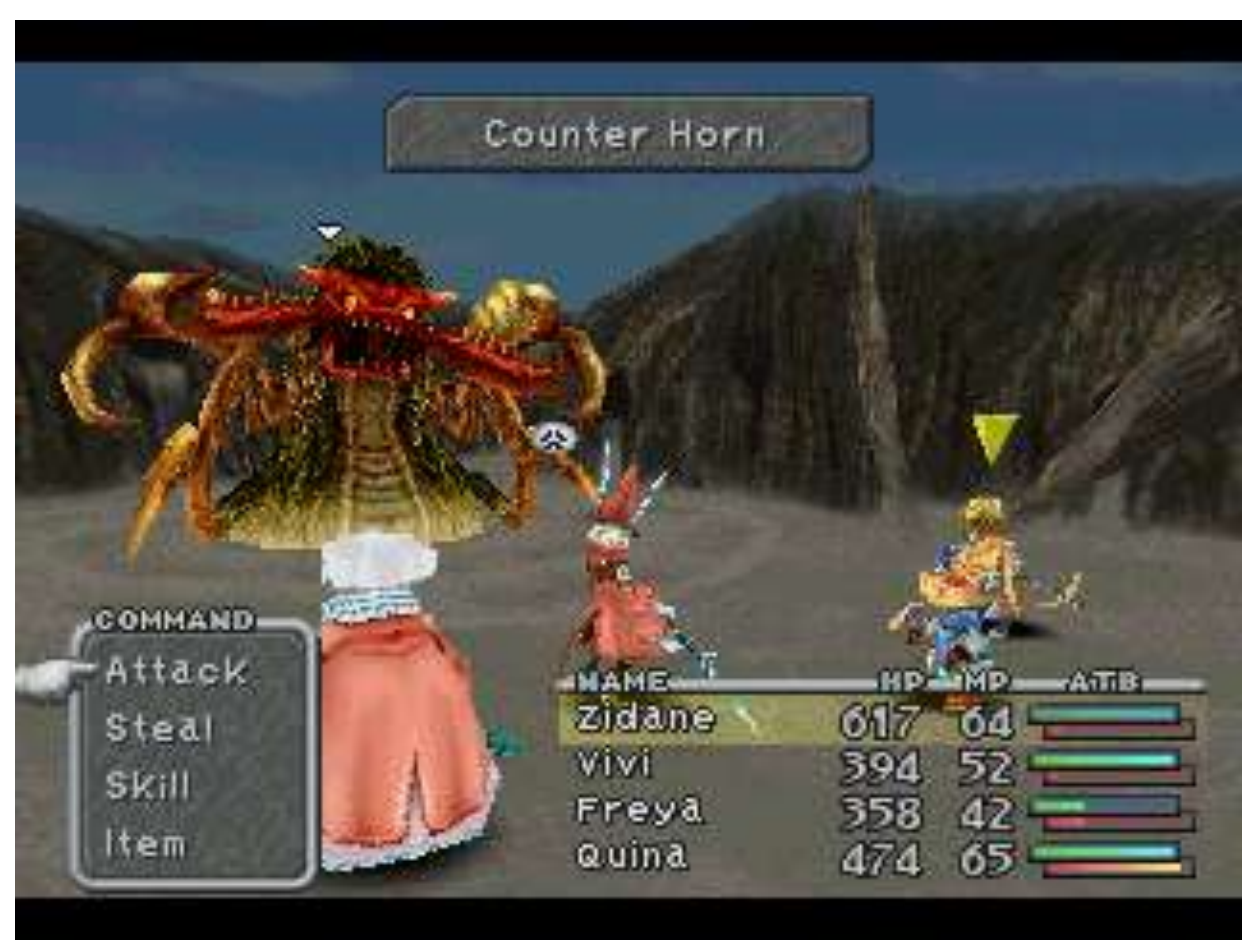

Imagem 6: Tela de batalha de Final Fantasy IX (Captura de tela)

A ordem das personagens no campo de batalha não tem, em Final Fantasy IX, influência alguma sobre a barra de ATB ou sobre qualquer outro aspecto da batalha; a distância entre cada personagem e os inimigos, no entanto, é crucial. Há, como pode ser visto na imagem acima, dois alinhamentos possíveis: a fileira $A$ e a fileira $B$. Personagens alocadas na fileira $A$ encontram-se mais próximos dos inimigos e podem atacá-los diretamente com mais força; há, porém, a desvantagem de estarem mais vulneráveis a ataques diretos inimigos. As personagens da fileira B, por sua vez, encontram-se mais distantes e seus ataques diretos são menos poderosos; há, em contrapartida, a vantagem de que ataques diretos inimigos também o são. Formas de ataques alternativos (como feitiços) ou ataques diretos feitos com armas de longa distância têm o mesmo poder em qualquer uma das fileiras. 


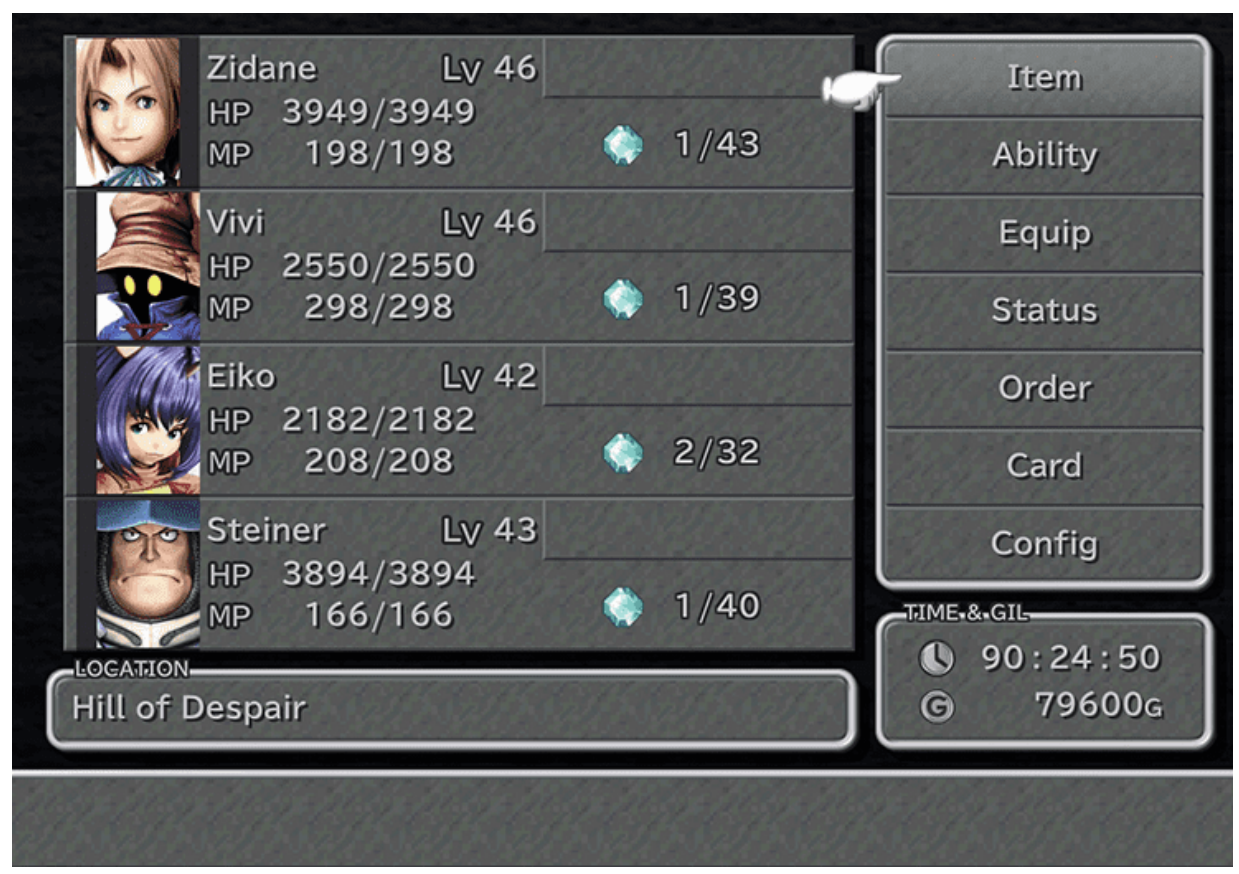

Imagem 7: Tela de menu de Final Fantasy IX. É possível ver Zidane na fileira A, enquanto Vivi, Eiko e Steiner (surpreendentemente) encontram-se na fileira B. (Captura de tela)

Todo o sistema de jogabilidade de Final Fantasy IX, portanto, gira em torno do arranjo das personagens nas batalhas: cada uma delas é única na medida em que dispõe de uma lista finita e específica de habilidades, e de equipamentos a utilizar, os quais determinarão a melhor estratégia - certas personagens precisam ficar na fileira $A$, enquanto outras têm melhor desempenho na fileira B. Como Final Fantasy IX é um jogo em que cada personagem tem uma classe específica e não há maneira alguma de modificar quais equipamentos podem ou não ser utilizados, as estratégias são, em certa medida, bastante óbvias e, muitas vezes, já sugeridas para o jogador.

A personagem Freya, por exemplo, já se encontra alocada na fileira B ao entrar no grupo, enquanto Steiner é pré-designado na fileira A, muito embora ambos partilhem dos mesmos tipos de armaduras. O que determina essa pré-disposição de Freya para a fileira B é o seu conjunto de habilidades: ela é capaz de utilizar o comando de Salto (Jump), característico da classe Dragoneiro (Dragoon) na série Final Fantasy.

O comando de Salto faz com que Freya literalmente salte para longe do campo de batalha e fique invulnerável por certo período de tempo, durante o qual o jogador também será impedido de designar a ela qualquer outro comando; após esse intervalo de "ócio", Freya aterrissará em cima do inimigo cravando sua lança nele, ataque que ignora o quesito de distância entre as fileiras das personagens e a dos inimigos - ou seja, ela causará a mesma quantidade de dano ao inimigo estando posicionada na fileira A ou 
B. Steiner, por sua vez, não possui nenhum tipo de comando direto que the permita evadir-se dessa característica do sistema, fazendo com que a fileira à qual ele é designado afete diretamente sua performance ofensiva.

Nossa análise de Final Fantasy IX no que diz respeito às intersecções entre mecânica de jogo e gênero atribuído as personagens no campo figurativo e narrativo será centrada nesse tipo de diferença, tendo em vista que há uma tendência à pré-disposição de personagens femininas à fileira $B$ enquanto personagens masculinas são designadas à $A$. Isso se dá devido a diversos fatores, sobretudo à sua suposta fragilidade inerente e ao fato de que elas são capazes de se valer de meios furtivos para tornar nulas a penalidade ofensiva da fileira anterior - como Freya o faz, ao esquivar-se da batalha para surpreender os inimigos.

\section{Papeis de gênero}

A intersecção temática entre papéis de gênero e papéis desempenhados por jogadores em jogos de RPG não é simples coincidência; há um direcionamento bastante claro e recorrente que demonstraremos ao longo das análises desta Tese, o qual tem sua base no conceito de isotopia. No Dicionário de Semiótica (Greimas e Courtés, 2012, pp. 275-8), isotopia é definida como uma iteração ou recorrência de traços, sejam eles temáticos, figurativos ou de outra ordem, a qual garantem a um discurso qualquer sua homogeneidade - ou, em nosso caso, uma suposta coerência.

A ideia é a de que o traço de feminilidade precise existir em todos os aspectos da constituição de uma personagem para que ela seja verossímil dentro do universo de um jogo; tendo em vista que a feminilidade é frequentemente associada à fragilidade, à manipulação e à furtividade, torna-se quase um padrão da indústria de jogos digitais desenvolver personagens femininas que tenham jogabilidade forte ou totalmente direcionada a estratégias coerentes com esses traços. Sendo assim, enquanto homens desempenham papéis de guerreiros, mulheres são magas ou assassinas; normalmente, curandeiras ou especialistas em venenos.

No caso de Final Fantasy IX, os traços de feminilidade são bastante aproximados da infantilidade: há duas personagens-criança, Vivi, um mago de nove anos de idade, e Eiko, uma evocadora e curandeira de seis anos. Ambos, evidentemente, são alocados na fileira B e dependem exclusivamente de poderes mágicos para serem eficientes; no 
entanto, enquanto Vivi tem um aspecto altamente ofensivo em seu arsenal, Eiko é a personagem mais versada em habilidades curativas disponível no jogo. Toda a capacidade ofensiva de Eiko é limitada a um feitiço, que concentra energia sagrada e é aprendido quase no fim do jogo (Holy, um dos nomes recorrentes na série), ou à evocação de entidades conhecidas como Eidolons, as quais entram na luta para desferir um golpe devastador.

Trata-se, em suma, de um conjunto de dinâmicas de jogabilidade que relegam à personagem masculina os traços de agressividade e autossuficiência, enquanto a personagem feminina tem seu valor indireto, determinado por sua capacidade de dar suporte às demais personagens ou por trazer ao campo de batalha alguém que lute em seu lugar. No caso de Eiko, seus Eidolons têm diversos traços de suporte e não necessariamente de ataque, e seu feitiço ofensivo só funciona bem contra inimigos vulneráveis ao elemento sagrado, o que limita claramente sua ação.

Seria exaustivo - e desnecessário - analisar cada ponto de todas as personagens femininas do jogo. Por isso, iremos nos limitar às personagens que parecem quebrar o estereótipo feminino, porém não o fazem; são elas: Freya, a Dragoneira já mencionada, e Beatrix, uma das antagonistas que, em determinado ponto da história, muda de lado e torna-se controlável por um curto período de tempo. Ambas são personagens cuja força física e proezas marciais são exaltadas narrativamente, porém sua jogabilidade entra em desacordo com essa informação uma vez que todas as personagens masculinas nãoinfantis são capazes de superá-las fisicamente; além disso, o meta-jogo de Freya não envolve nenhuma habilidade física e sim um tipo especial de feitiçaria bastante similar às evocações.

A hipótese que defenderemos aqui é a de que, muito embora a superfície da narrativa diga o contrário, as isotopias referentes à fragilidade e furtividade são mais presentes no modo como o jogador vive a experiência narrativa enquanto controla essas personagens; esse aspecto em um jogo é, como defendemos ao longo desta Tese, o cerne da atividade lúdica e o epicentro de seu conteúdo narrativo.

\section{Lute como uma garota}

Freya tem um desenvolvimento narrativo bastante acidental em Final Fantasy IX. Assim como Amarant e Quina, não há nenhuma ligação direta forte entre ela e a trama 
central do jogo; Freya simplesmente é uma velha amiga de Zidane que, por estar no mesmo lugar em determinado ponto da narrativa, junta-se ao grupo para um jantar. Lá descobre que sua terra natal (o Reino de Burmecia) está sendo atacada pela Rainha Brahne e parte junto com os demais para averiguar a situação e tentar salvar seu rei. Após as batalhas, esse arco da história se fecha com a derrota de Burmecia, porém Freya continua no grupo protegendo a princesa Garnet. Seus motivos não ficam explícitos, embora possam ser explicados por um desejo de vingança ou de impedir que o desastre em Burmecia se repita, e não há mais nenhum envolvimento direto entre Freya e o restante da trama - diferente de Zidane, Garnet, Vivi e Eiko, cujas histórias de base são fundamentais para o acontecimento, e até mesmo de Steiner, que tem uma ligação forte com a princesa por ser membro da guarda de Alexandria. Nesse sentido, Freya é uma personagem secundária, embora esteja entre as principais.

A história de base de Freya é bastante peculiar e interessante ao nosso estudo: ela era uma Dragoneira de Burmecia que abandona sua terra natal em busca de Sir Fratley, seu mentor e amante que partiu em uma jornada pelo Continente da Bruma e desapareceu. Vê-se aqui que, muito embora seja descrita como uma mulher forte e independente, membro de uma força militar de renome, Freya abandona tudo em busca de seu amor; seu propósito e sua inclusão praticamente acidental nos eventos da narrativa giram em torno de um homem, que, quando encontrado, está amnésico. O novo propósito de Freya passa, então, a ser o de impedir a Rainha Brahne - e posteriormente Kuja - de concluir seu plano de dominação, porém, como dito acima, não há mais ligação direta alguma entre sua história de base e os eventos; o que torna Freya única é sua relação amorosa e sua devoção ao amante/mestre. Além disso, há um consenso latente de que Sir Fratley é o Dragoneiro mais poderoso, o que coloca Freya como uma espécie de "prêmio de consolação" na narrativa: estando Sir Fratley amnésico, ela se torna a única de Burmecia capaz de tomar parte na luta contra o mal. Sendo assim, Freya é indiretamente caracterizada como uma personagem "menor": alguém que está hierarquicamente abaixo de seu mentor/amante e, portanto, precisa embarcar numa jornada de superação. 

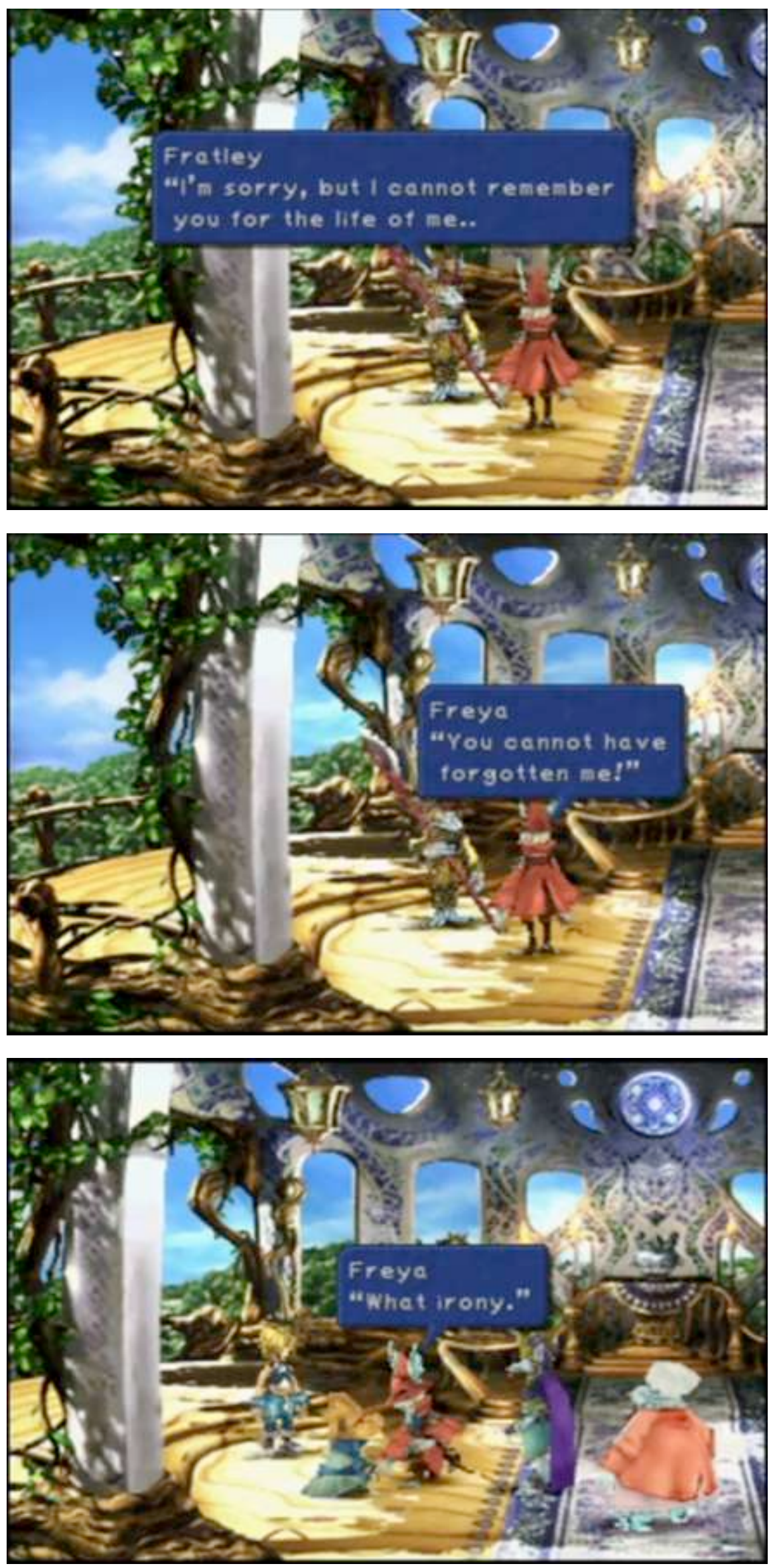

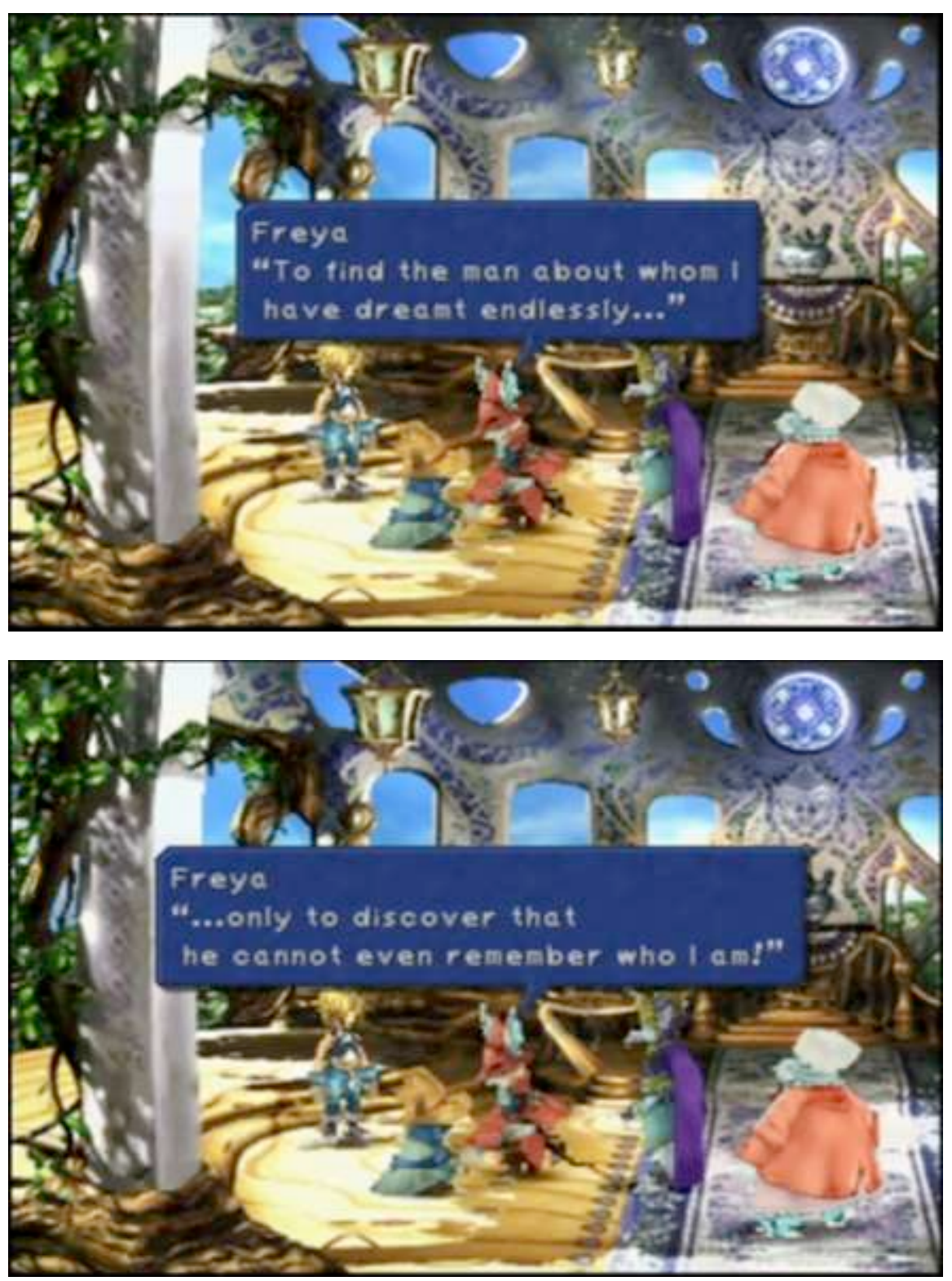

Imagens 8 a 12: O reencontro de Freya e Sir Fratley. (Captura de tela)

No que diz respeito à jogabilidade, a posição de Freya no meta-jogo corrobora essa leitura. Enquanto Dragoneira, Freya possui atributos comparados ao de Steiner, um Guerreiro: sua defesa e ataque são altos, e ela pode fazer uso de armaduras pesadas couraças, capacetes, grevas. Isso normalmente a caracterizaria como uma personagem apropriada para a linha de frente, localizada na coluna posterior; no entanto, seu metajogo difere consideravelmente desse perfil. Muito embora seu ataque seja relativamente alto em relação a todas as personagens do jogo, quando comparado apenas com as personagens adequadas à linha de frente, o ataque de Freya é, na verdade, o mais fraco: sua arma suprema, obtida em uma missão paralela e opcional, é a que tem pior 
desempenho em ataques físicos diretos, e o maior incentivo para obtê-la é o fato de permitir que Freya aprenda a técnica Dragon Crest.

Dragon Crest é a técnica de Dragoneira mais forte do jogo, capaz de atingir o teto de dano (9999 pontos). Para que isso ocorra, é preciso que o grupo mate monstros do tipo Dragão - quanto mais monstros desse tipo forem mortos, maior o dano; o que coloca

Freya num ponto mais próximo de personagens não-atacantes no meta jogo. Comparável a Eiko, sua força não vem de si mesma, mas dos dragões mortos pelo jogador durante todo o jogo - é, tematicamente, uma forma de evocação. Em termos de jogabilidade, fortalecer Freya torna-se uma tarefa repetitiva e entediante, uma vez que monstros do tipo dragão não são comuns no jogo e é preciso que o jogador derrote 100 deles para atingir o máximo de potência com Dragon Crest. Usando Steiner em vez de Freya, o jogador será capaz de atingir essa potência com muito menos trabalho.

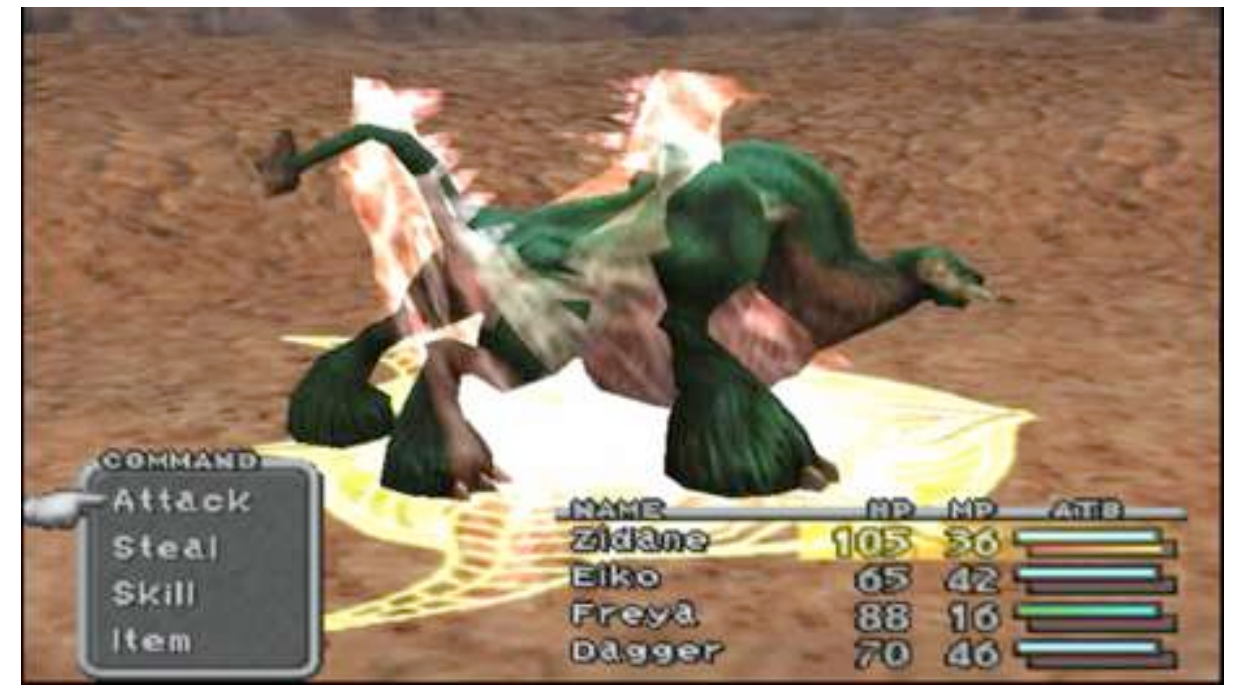

Imagem 13: Dragon Crest de Freya (Captura de tela)

Sendo assim, o verdadeiro valor de Freya pode ser medido em outros aspectos, como o de suporte: as demais técnicas de Dragoneiro têm em sua maioria a função de recuperar pontos de vida, recuperar pontos de magia ou causar efeitos negativos nos inimigos; as técnicas de combate são inferiores a Dragon Crest, e mesmo quando utilizadas são mais eficazes quando usadas na fileira anterior, caracterizando Freya como uma personagem não adequada à linha de frente no campo de batalha.

Se analisados isoladamente, esses aspectos de jogabilidade não trazem, em si, problema algum: é bastante comum em jogos de RPG haver personagens mais simples e 
diretas - como Steiner - e personagens mais complexas, cuja eficácia depende de estudo mais atento dos detalhes e finezas de cada componente. E, de fato, Freya é sob muitos pontos de vista uma personagem melhor que Steiner, uma vez que ela é capaz de desempenhar diversos papéis a que ele não tem acesso e também, com um pouco de trabalho e dedicação, causar tanto dano quanto ele. Todavia, quando os aspectos narrativo e temático são analisados em conjunto com os aspectos de mecânica de jogo, nota-se um reforço de estereótipos de gênero que colocam Freya no grupo de personagens que se valem de subterfúgios para vencer - sua força vem de magia ou furtividade, não de algo a ela inerente.

Isso fica claro quando analisamos outra personagem, Beatrix, que tem um desenvolvimento narrativo muito diferente do de Freya, mas que, por causa de sua jogabilidade, é dela bastante próxima. Beatrix é, assim como Steiner, membro da força militar de Alexandria, mas diferente dele ela angariou para si bastante prestígio no Continente da Bruma: Beatrix é considerada a melhor e mais forte espadachim de todo o mundo, incomparável em sua técnica. Na primeira metade do jogo, Beatrix se coloca como um dos mais fortes oponentes; há três confrontos entre ela e o jogador, e em todos eles há uma mecânica similar: é impossível derrotá-la. O jogador deve simplesmente sobreviver por um determinado período de tempo, que pode ser maior ou menor dependendo de quanto dano ele é capaz de causar a ela; quando qualquer uma das condições for satisfeitas - o dano causado é suficiente ou o tempo pré-determinado passa -, Beatrix irá desferir um golpe fatal para encerrar a batalha.

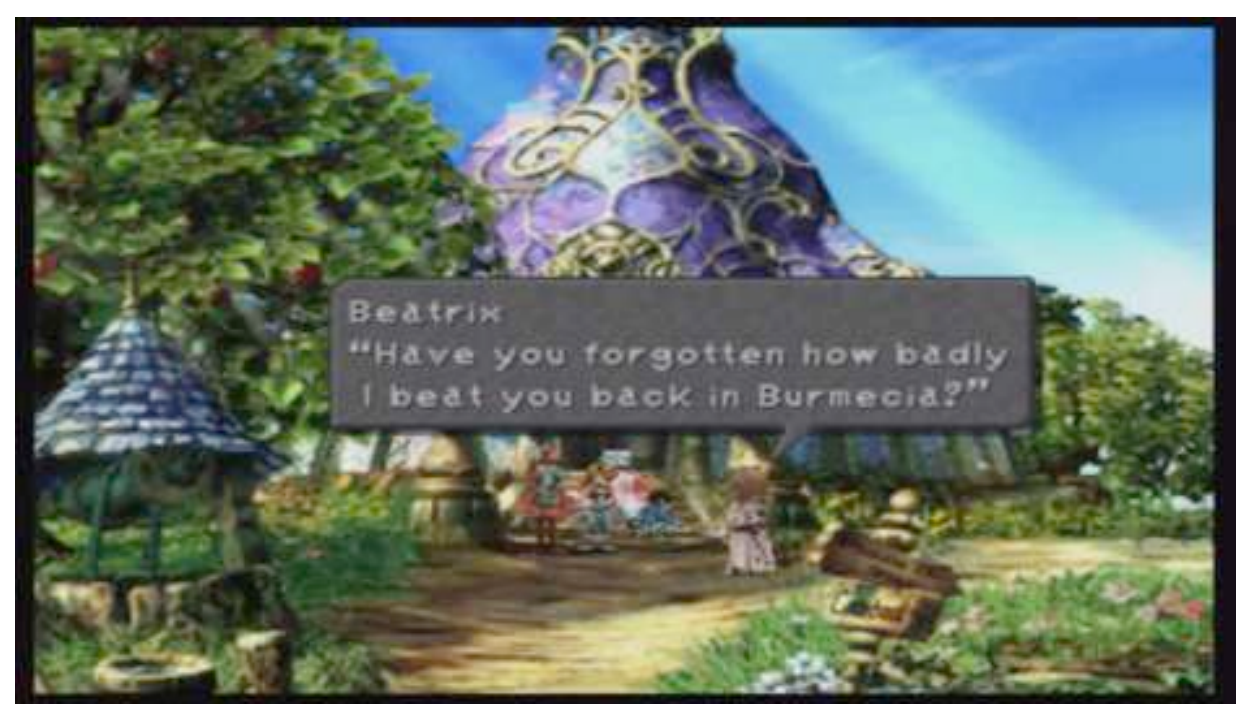



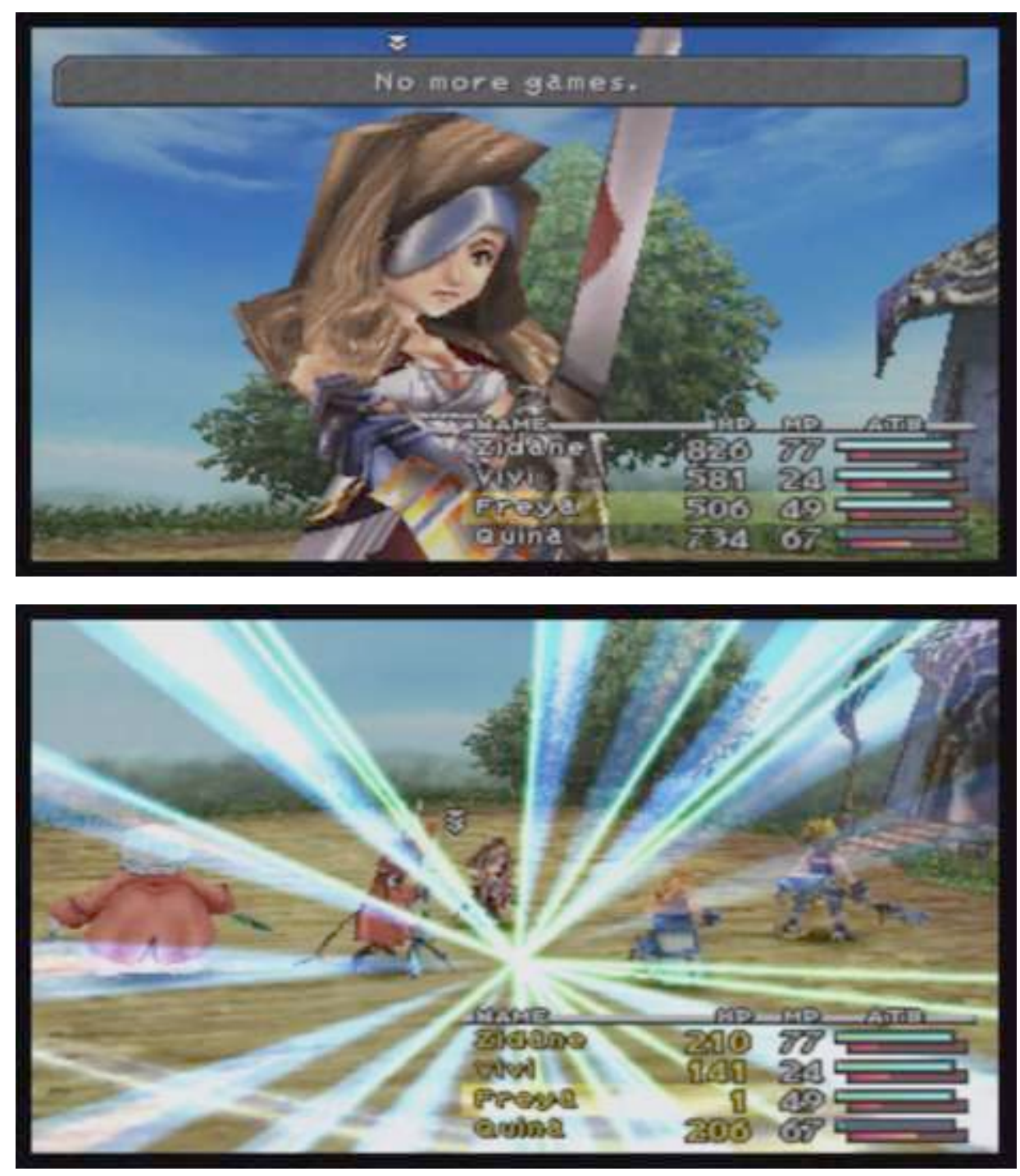

Imagens 14 a 16: Luta contra Beatrix na cidade de Cleyra, finalizada com um golpe fatal que reduz os Pontos de Vida do grupo a 1. (Captura de tela)

Essa mecânica de jogo corrobora a história de base de Beatrix, tornando-a um oponente formidável e lendário; no entanto, a ilusão é quebrada na ocasião em que a personagem muda de lado na história. Ao perceber que as intenções e ações da Rainha Brahne não são justificáveis, Beatrix se volta contra ela e passa a defender Garnet, entrando temporariamente no grupo; o jogador passa a controlá-la junto com Steiner e Freya, o que coloca os atributos de Beatrix em comparação direta com o de seus dois competidores diretos - uma vez que ela faz uso do mesmo tipo de armadura e tem atributos similares, muito embora mais fracos. Ao atacar diretamente o inimigo, o jogador irá causar mais dano com Steiner ou Freya do que com Beatrix; o único momento em que ela é mais forte que os demais é quando se faz uso de técnicas aos quais Steiner ainda não tem acesso - porém, caso isso fosse possível, ele seria matematicamente mais forte. 
Assim como ocorre com Freya, o diferencial de Beatrix vem de suas magias de cura e suporte, inacessíveis a Steiner. Com isso, verifica-se que todas as personagens femininas de Final Fantasy IX têm alguma forma de cura e suporte, o que não ocorre com as personagens masculinas: apenas Amarant tem acesso a esse tipo de habilidade - e ainda assim seus atributos de ataque físico são mais fortes do que os de Freya e Beatrix.

É importante salientar novamente que, de um ponto de vista puramente estrutural, não há problema algum na variação de estilos de jogabilidade ou em um jogo apresentar variação nos pontos fortes e fracos de cada personagem; porém é bastante significativo o fato de que todas as personagens femininas estão alinhadas com estilos mais furtivos e de suporte, enquanto as personagens masculinas - mesmo enquanto suportes - são ofensivamente fortes. Isso fica evidente quando se nota que Vivi é a única personagem masculina que não tem atributos físicos fortes, uma vez que é um Mago Negro geneticamente desenvolvido para isso e tem apenas nove anos de idade.

\section{Donzelas em apuros}

As demais personagens femininas do jogo, Garnet e Eiko, ocupam prioritariamente a posição de suporte em combate - são o que em outros jogos da série se caracteriza como Mago Branco, um especialista em cura; ofensivamente, são capazes de evocar entidades chamadas Eidolons, no entanto, o custo de Pontos de Magia cria uma pequena barreira ao jogador: não é viável realizar tantas evocações em sequência como Garnet ou Eiko sem correr o risco de se gastarem todos os Pontos de Magia disponíveis e ter de se recorrer a itens de restauração. Em contrapartida, o comando de Magia Negra de Vivi apresenta um custo menor para magias ofensivas, além de ter em seu arsenal a magia Osmose, que recupera Pontos de Magia, e um atributo passivo opcional que reduz o custo de cada Magia Negra. Em suma, muito embora haja a possibilidade de jogar ofensivamente como Garnet ou Eiko, há muito mais restrições.

No que diz respeito à mecânica de jogo, essa diferença é justificada dado o alto poder destrutivo de um Eidolon, capaz de atingir diversos inimigos no campo de batalha; o jogo ficaria menos desafiador caso o jogador pudesse recorrer a esse tipo de técnica constantemente. No entanto, quando a narrativa entra em cena, nota-se a reiteração do estereótipo já mencionado na seção anterior: mecânicas de restrição ofensiva são invariavelmente associadas a personagens femininas. No caso de Garnet e Eiko, isso é 
ainda mais salientado pelo desenvolvimento de enredo: ambas precisam ser salvas mais de uma vez por Zidane, o protagonista masculino.
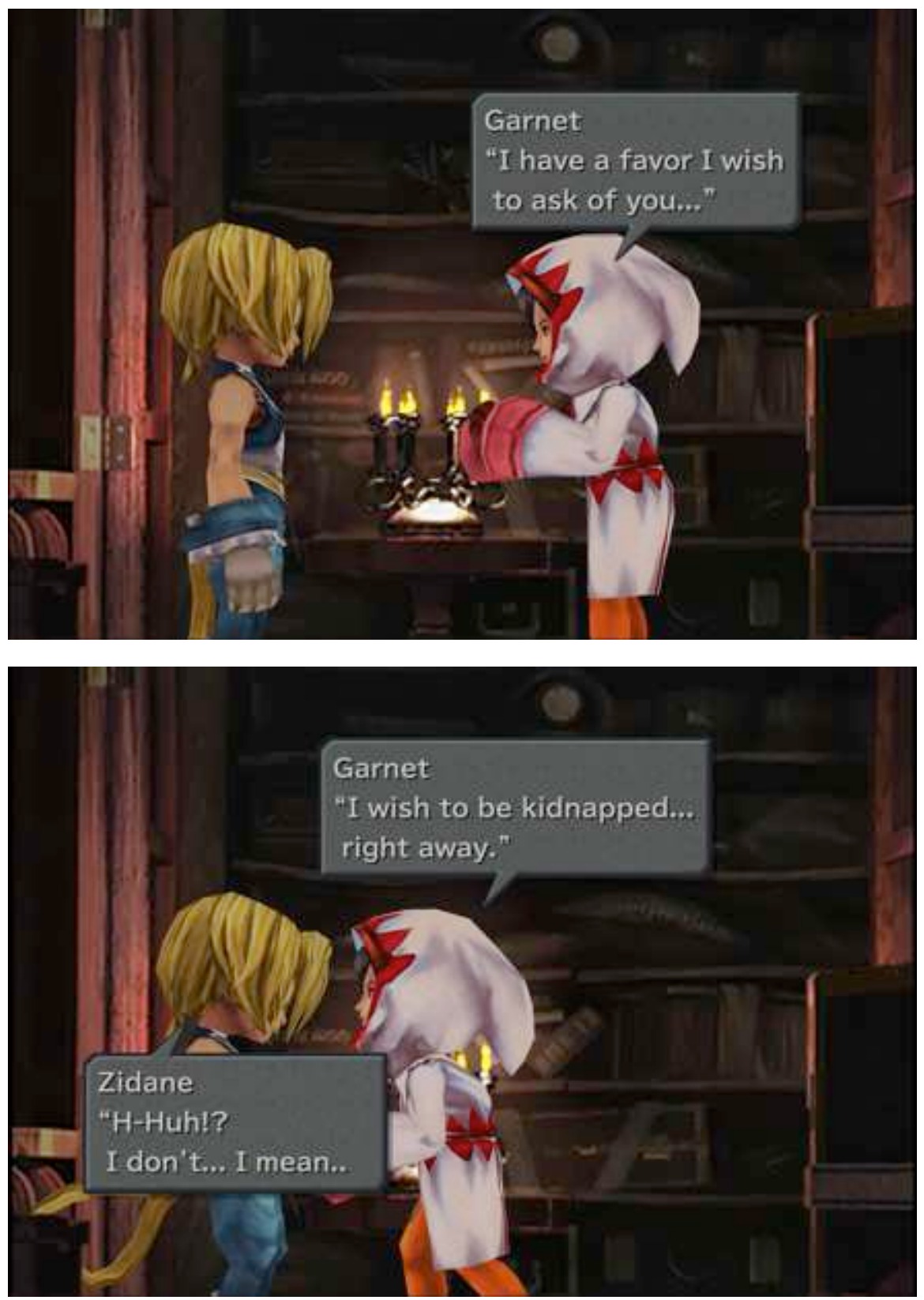


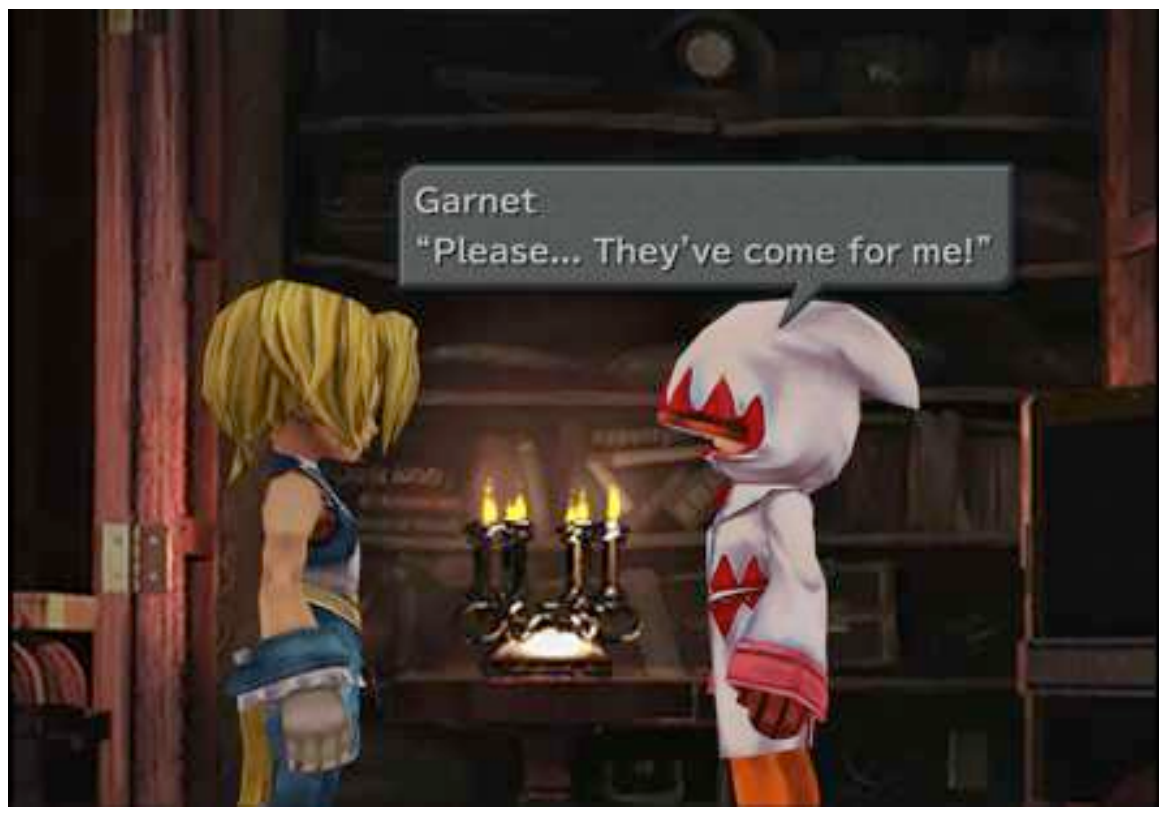

Imagens 17 a 19: Garnet implora a Zidane para que a sequestre de Alexandria e a leve a Lindblum.

(Captura de tela)

Desde o início, Garnet é colocada como a princesa em apuros que precisa ser resgatada, e permanece no grupo como alguém a ser escoltado: enquanto Zidane quer levá-la ao reino de Lindblum a pedido do regente Cid, o governador, Steiner deseja levála de volta a Alexandria; seja como for, a segurança da princesa é sempre vinculada a uma figura masculina. Isso é reforçado pelo fato de que, nesse ponto do jogo, Garnet não tem acesso a nenhum de seus Eidolons: todos eles têm um custo de Pontos de Magia maior do que o total de que Garnet dispõe, o que inviabiliza matematicamente sua evocação e faz com que curar seja a única ação eficiente disponível para ela.

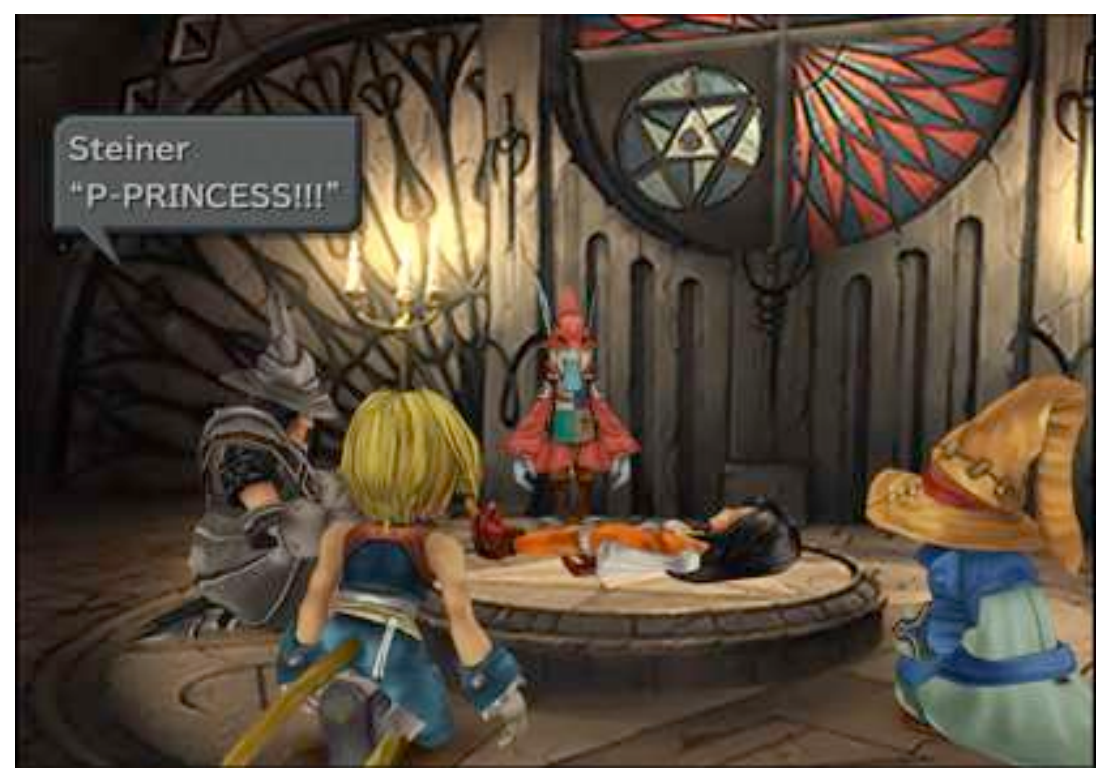




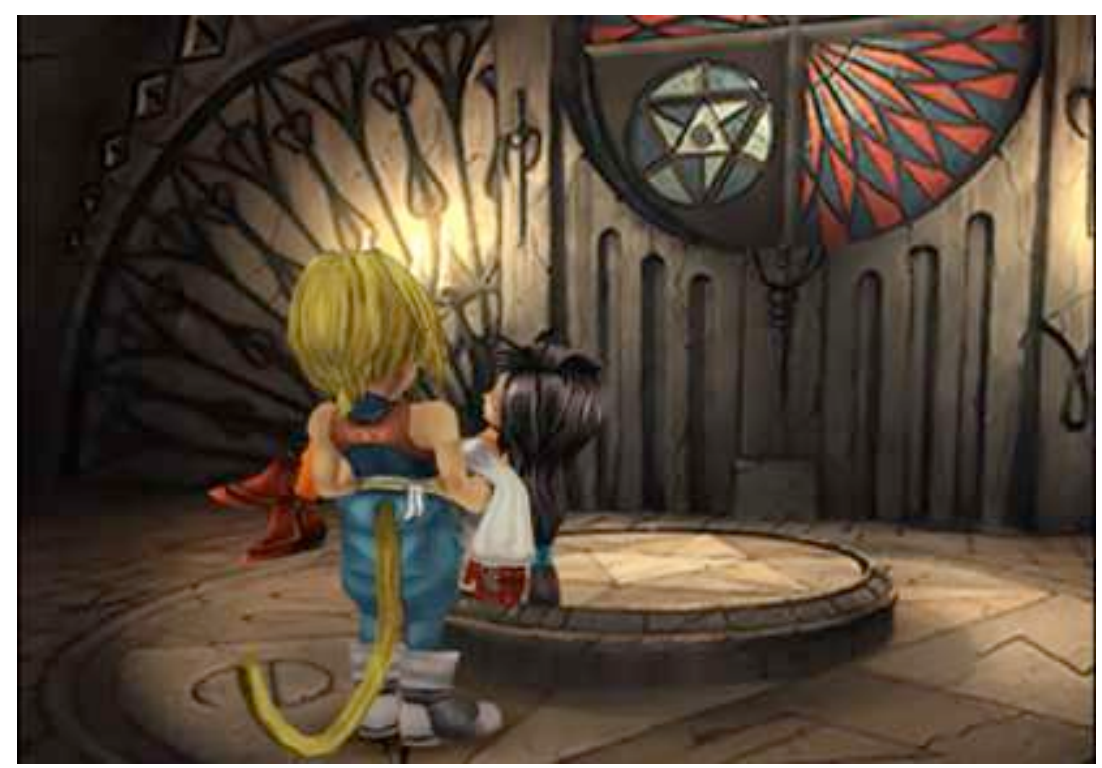

Imagens 20 e 21: Garnet é resgatada pelo grupo após ser capturada pela Rainha Brahne. (Captura de tela)

A falta de eficiência ofensiva de Garnet em combate é mecânica e tematicamente reiterada por um grande período no jogo, e sua jornada é, em grande parte, um percurso lento de crescimento pessoal e busca de autossuficiência. Há, inclusive, uma porção do jogo em que ter Garnet no grupo é prejudicial; devido a um trauma pessoal, a princesa fica incapaz de falar, e durante o combate qualquer uma de suas ações pode ser interrompida aleatoriamente - é como se ela "engasgasse". É apenas nos estágios finais da narrativa que Garnet se torna uma personagem mais interessante do ponto de vista da jogabilidade e atinge o grau de versatilidade que mencionamos anteriormente, muito embora ainda assim ofensivamente inferior a todos os demais com exceção de Eiko que funciona muito melhor como suporte desde sua inclusão no grupo.

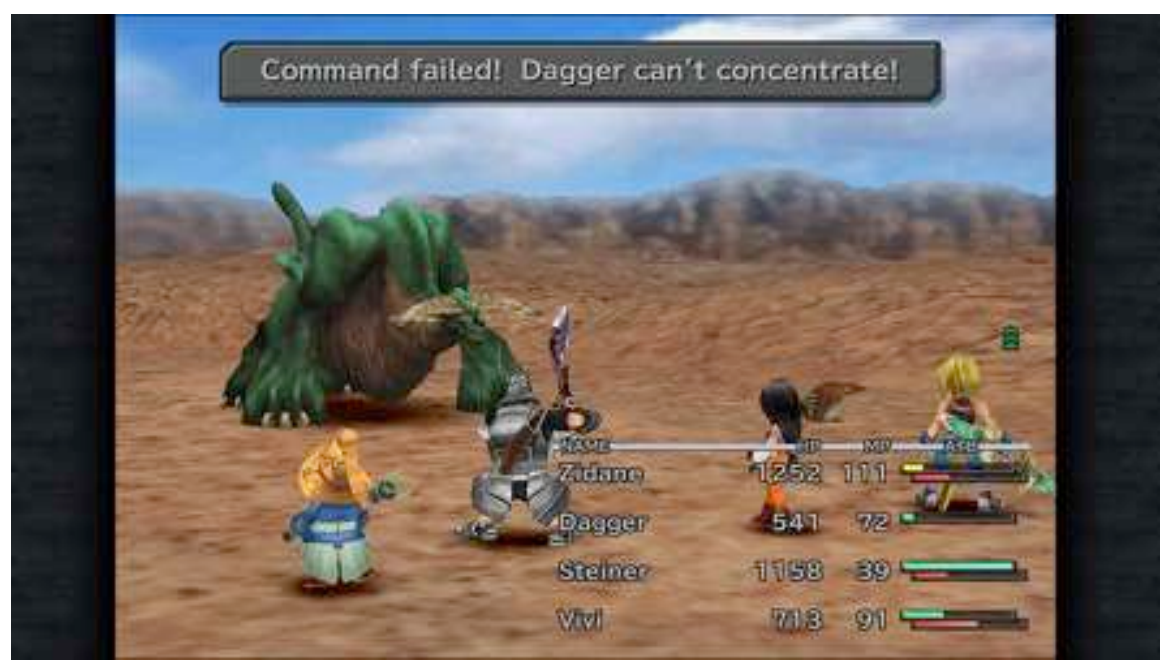

Imagem 22: Garnet (Dagger) não consegue agir em combate devido a seu trauma. (Captura de tela) 
O percurso de Eiko é bastante relacionado com o de Garnet, uma vez que são Evocadoras e têm como local de nascimento a tribo de Madain Sari, no Continente Exterior $^{62}$. Sendo as últimas sobreviventes do clã dos Evocadores, ambas são alvo das intensões de Brahne e Kuja - que desejam controlar os Eidolons para fins de conquista militar - e devem ser protegidas por Zidane. No caso de Eiko, que é uma criança de seis anos, a incapacidade de se defender sozinha é evidente - muito embora ela tenha sobrevivido isolada na vila de Madain Sari por um longo tempo apenas com a ajuda de Moogles $^{63}$, sem nenhum adulto, já que todos os demais evocadores estão mortos. 0 aspecto mais interessante da relação entre Eiko e Garnet, no entanto, é a temática estereotipada da rivalidade feminina e do ciúme: impressionada com Zidane e grata por ter sido por ele salva na vila de Conde Petie, Eiko desenvolve uma "paixonite" pelo herói e, em consequência, um leve sentimento de animosidade por Garnet, que, em sua opinião, não é boa o suficiente para o seu amor.

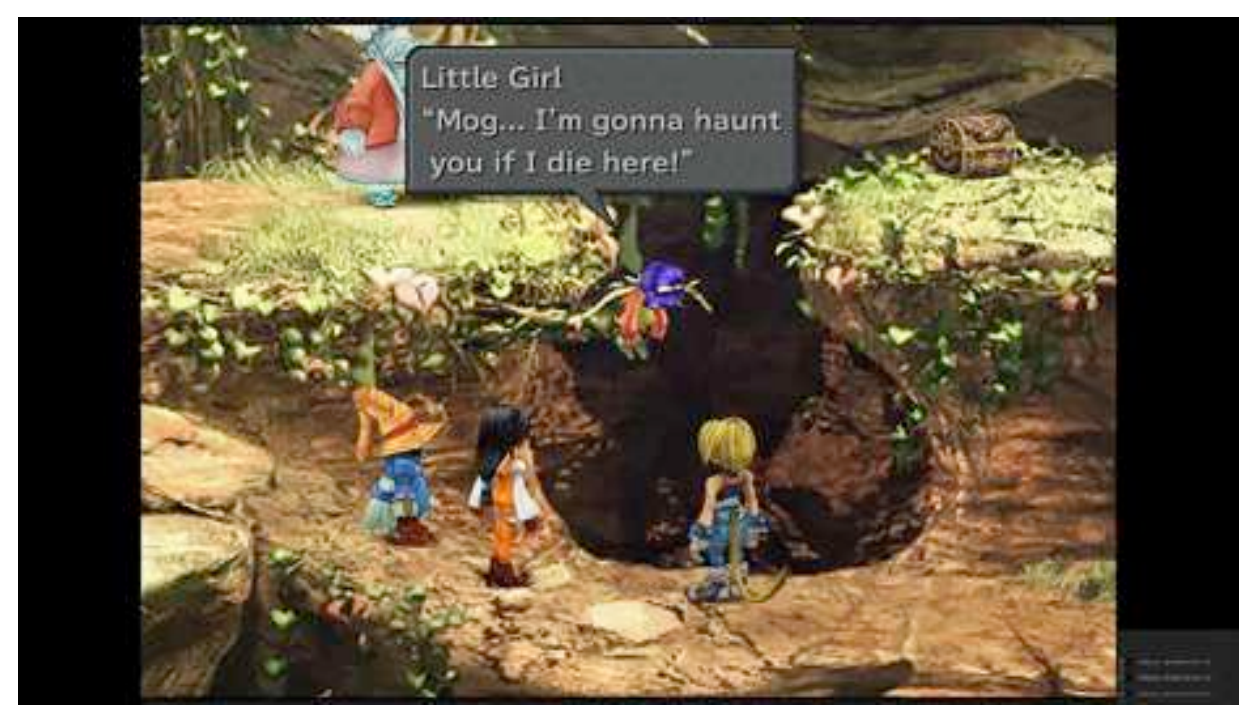

Imagem 23: Eiko é salva por Zidane e os demais membros do grupo após ficar presa em um galho.

(Captura de tela)

As peripécias da narrativa fazem com que esse pequeno evento perca importância, porém é, em nossa análise, crucial para o desenvolvimento dos estereótipos femininos em Final Fantasy IX na medida em que introduz a personagem por meio de um

\footnotetext{
${ }^{62}$ Ao encontrar Eiko, descobre-se que Garnet não é filha biológica da Rainha Brahne, tendo sido adotada pelo falecido Rei após aparecer à deriva em um pequeno barco.

${ }^{63}$ Moogles são criaturas mágicas recorrentes na série Final Fantasy. São conhecidos por sua graciosidade e por gostarem de pregar peças.
} 
clichê frequentemente usado para inferiorizar mulheres e vincular sua existência a uma figura masculina qualquer; no caso em questão, há tom satírico, uma vez que Eiko é apenas uma criança de seis anos, no entanto a necessidade de introduzi-la dessa forma nos chama a atenção - todas as personagens femininas em Final Fantasy IX têm algum tipo de figura masculina às quais estão ligadas: Garnet e Eiko são rivais em sua relação com Zidane; Freya baseia toda sua jornada em sua busca por Sir Fratley (até o encontro com o grupo, pelo menos); e até mesmo Beatrix que, muito embora seja considerada superior a Steiner no início do enredo, com ele se relaciona amorosamente a partir da segunda metade do jogo (além da já mencionada inferioridade em termos de jogabilidade).
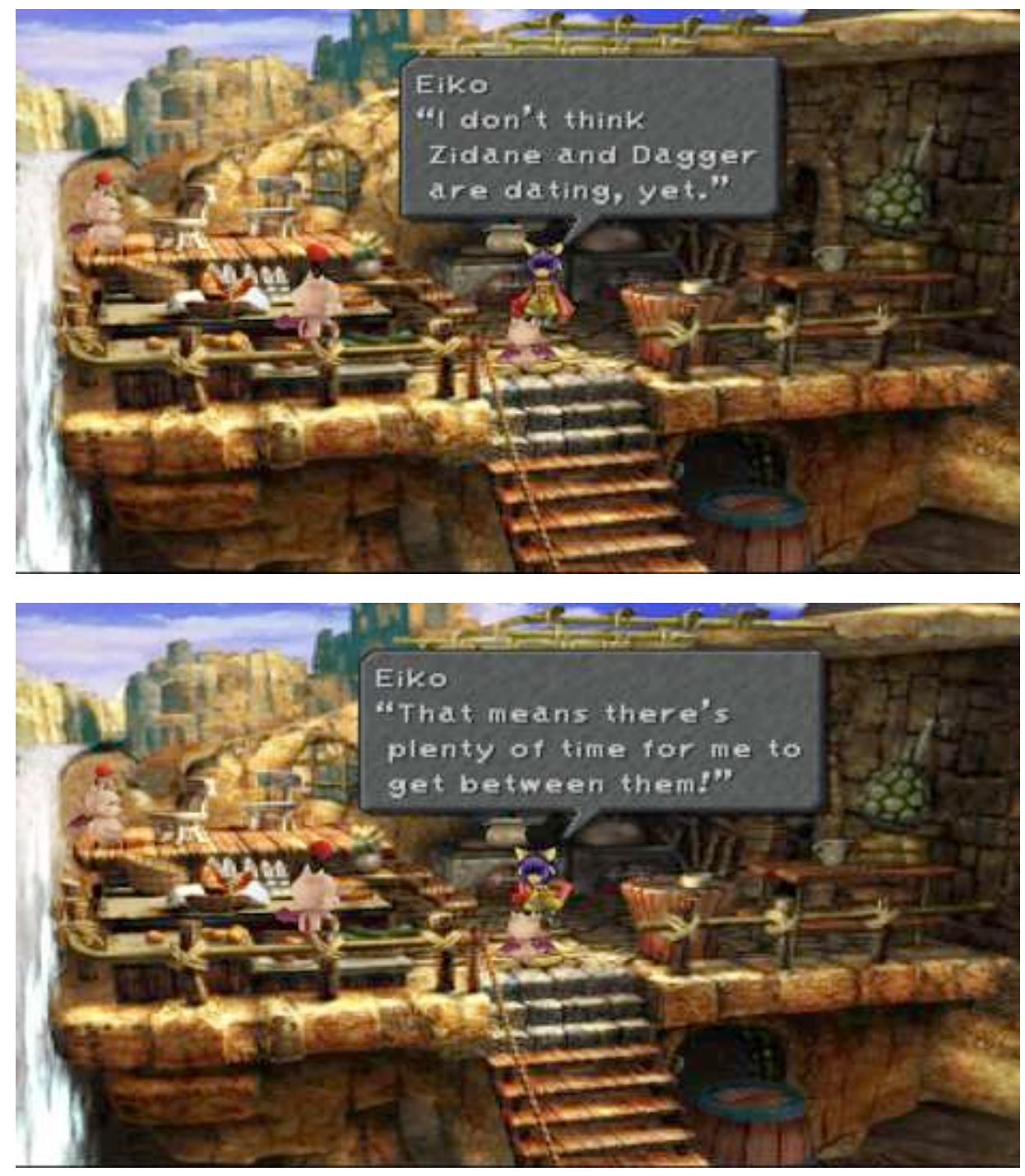


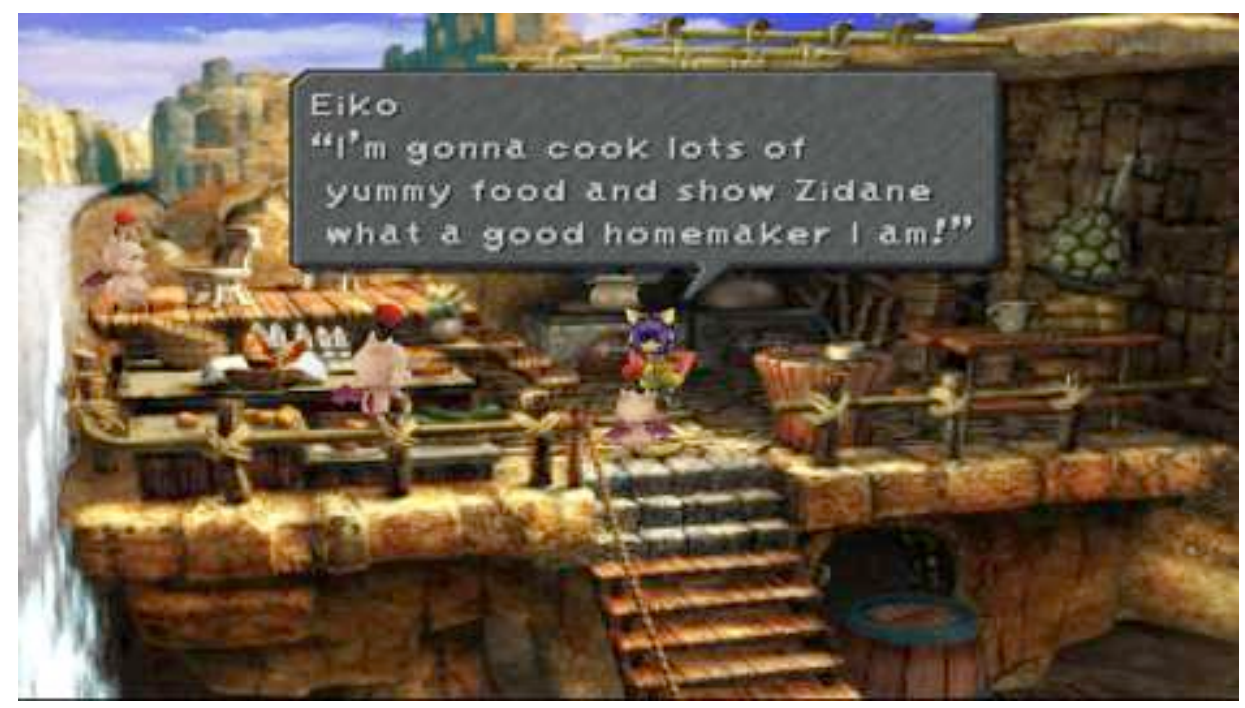

Imagens 23 a 25: Eiko arquiteta um plano para roubar Zidane de Garnet (Dagger). (Captura de tela)

Vê-se, portanto, que, apesar de diversos eventos e temáticas com intuito de tornar as personagens femininas fortes, demonstrando seu crescimento pessoal e sua força de combate, essas tentativas de fortalecimento acabam, ao fim e ao cabo, falhando em consequência de percursos temáticos conflitantes que retomam os clichês narrativos da donzela em perigo: não importa a força que tenham, as mulheres de Final Fantasy IX ainda precisam ser salvas por um homem.

\section{A bestialidade do Outro}

Além da construção problemática do feminino, Final Fantasy IX apresenta um outro aspecto que nos interessa: a construção bestial daquele que não se conforma, tal qual representada no tratamento da personagem Quina. Sem gênero definido, ela é tratada de modo bastante idiossincrático na narrativa, uma vez que não aparenta ter qualquer tipo de noção a respeito dos eventos que a cercam e sua única motivação para seguir com o grupo é comer: membro do clã dos Qu - uma espécie bastante peculiar de criaturas que vivem em pântanos e se alimentam de sapos -, Quina decide expandir seus horizontes gustativos e saborear o maior número de coisas que puder ao redor do mundo.

Essa característica da personagem se reflete em sua mecânica de jogo, uma vez que Quina é classificada como um Mago Azul, uma classe recorrente na série Final Fantasy cujo diferencial se baseia no aprendizado de técnicas dos inimigos: em alguns 
jogos da série, Magos Azuis aprendem magias ao serem atingidos; em outros, basta que o oponente faça uso da técnica enquanto o Mago Azul estiver no grupo; no caso de Quina, ela deve comê-los.

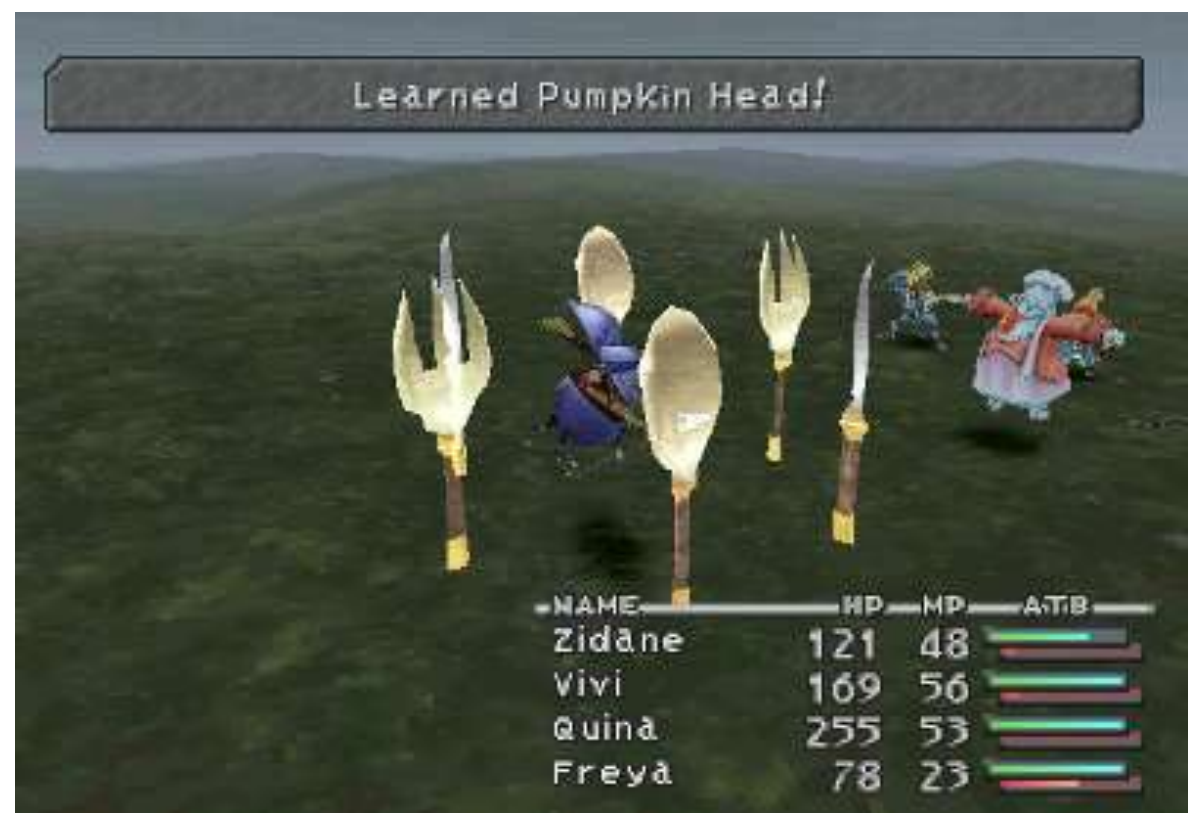

Imagem 26: Quina come um inimigo para absorver a habilidade Pumpkin Head. (Captura de tela)

Isso a torna uma personagem bastante versátil em combate, capaz de causar dano, curar, dar suporte aos aliados e atrapalhar os inimigos; além disso, Quina é uma das personagens mais resistentes do jogo devido ao seu alto número de Pontos de Vida. Seu ataque mais poderoso, chamado Frog Drop, é uma das técnicas capazes de atingir o teto de dano (9999), porém para chegar a esse número é preciso participar diversas vezes de um minigame opcional nos diversos pântanos dos Qu espalhados pelo mundo, o qual consiste em capturar sapos para Quina comer; quanto mais sapos, maior o dano de Frog Drop.

Embora não seja mecanicamente muito diferente do que ocorre com Freya e a caça aos dragões, tematicamente, o processo de fortalecimento de Quina envereda pela comicidade - a personagem como um todo é, em muitos pontos, um dos alívios cômicos do jogo. Um dos únicos momentos em que há uma necessidade narrativa para Quina é quando o grupo precisa se deslocar do Continente da Bruma para o Continente Exterior e não é capaz de localizar o túnel subterrâneo oculto capaz de levá-los até lá; Quina o encontra por acidente ao desembestar atrás de um sapo no pântano dos Qu localizado 
no Continente da Bruma. Após esse momento, não há mais qualquer justificativa para a personagem e ela permanece no grupo apenas por seus objetivos próprios já mencionados, funciona de fato como alívio cômico. O que nos interessa a esse respeito é o fato de que Quina não é simplesmente grande e desajeitada, mas é também incapaz de "falar direito": como demonstrado nas imagens abaixo, o inglês de Quina está em desacordo com diversas regras básicas da norma padrão da língua inglesa.
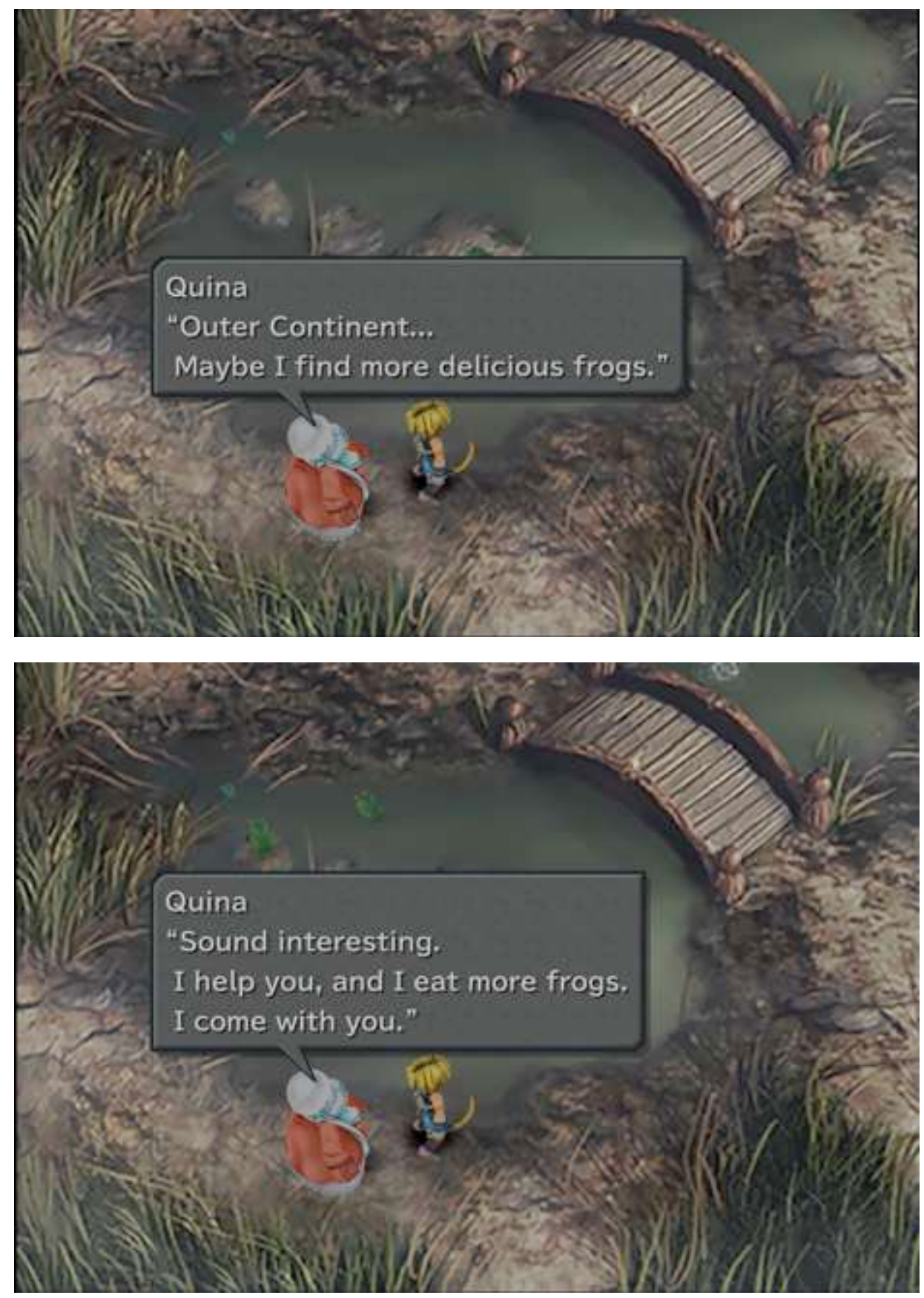


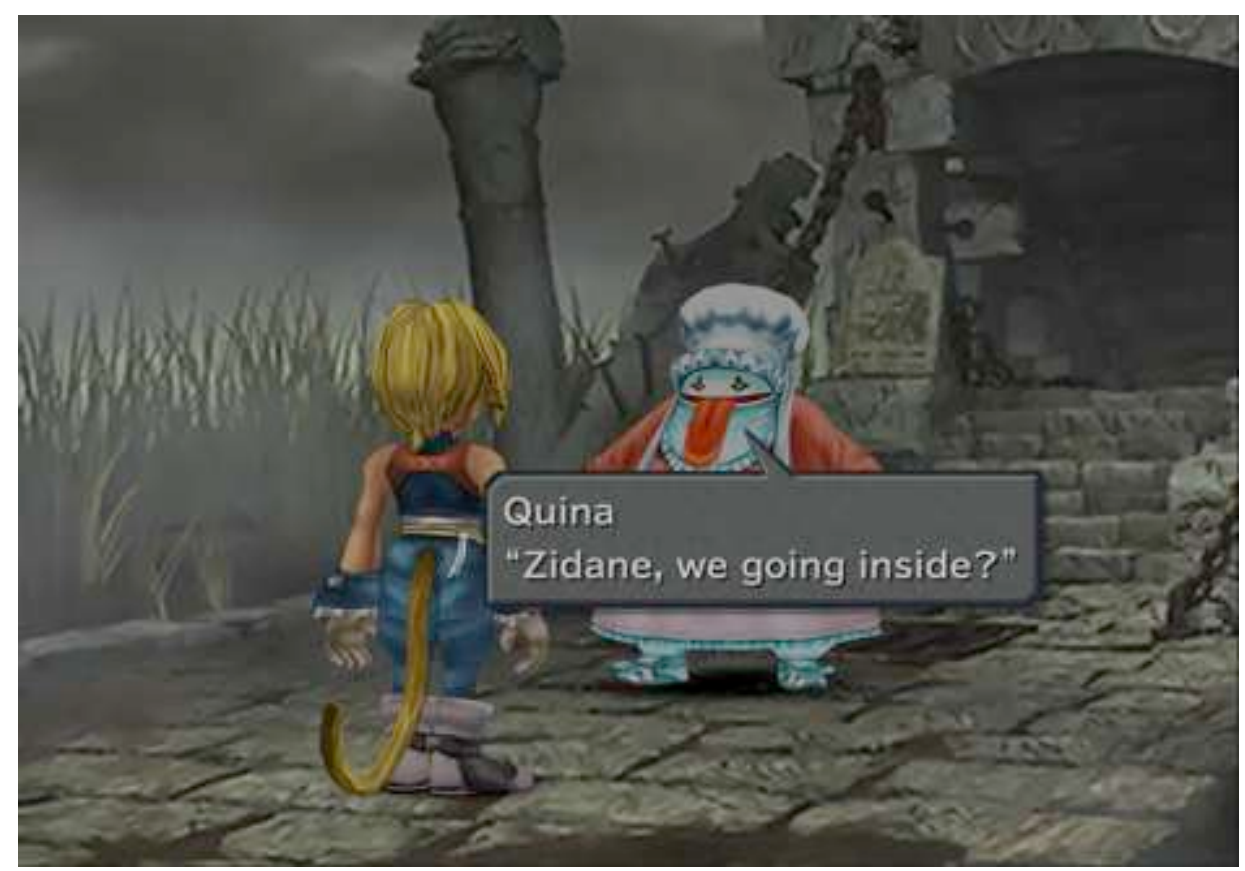

Imagens 27 a 29: O inglês "quebrado" de Quina (Captura de tela)

A marcação de origens ou classes sociais distintas por meio de diversas variantes linguísticas é bastante comum em jogos. Personagens mais pobres em geral apresentam uma versão "mais tosca" do idioma, piratas falam de acordo com o que se concebe como "pirate English" e tipos esnobes são pomposos em seus usos linguísticos. No entanto, a fala de Quina chama a atenção em particular no que toca o nosso estudo uma vez que coloca como marca de bestialidade a incapacidade de articular-se apropriadamente em inglês, o que é bastante associado ao modo como não falantes de inglês se comunicam no mundo real: em interações linguísticas, não é incomum que pessoas da América Latina, por exemplo, façam uso de uma versão extremamente simplificada da língua inglesa - uma espécie de "Spanglish" - com o intuito de comunicar suas necessidades mais básicas. A associação desse tipo de uso linguístico aos traços de comicidade e bestialidade é, sob nosso ponto de vista, uma espécie de analogia do Outro como não-humano, e é uma das formas de exclusão que veremos quando analisarmos jogos online. No caso de Final Fantasy $I X$, as consequências internas da narrativa são praticamente nulas, porém uma parcela considerável de jogadores não pertencentes aos centros de produção e recepção de jogos estão muito mais próximos de Quina que das demais personagens do jogo; esse tipo de associação, como veremos mais adiante, é extremamente problemática em jogos online. 


\section{Final Fantasy $X$}

Final Fantasy X, lançado em 2001 também pela Squaresoft, apresenta um desenvolvimento das personagens femininas e bestiais ${ }^{64}$ bastante similar ao de Final Fantasy IX, muito embora pareça em superfície distinto. Isso ocorre por uma diferença crucial no sistema de evolução de personagens, que à primeira vista caminha para uma personalização grande, mas é em profundidade bastante similar ao modelo de classes fixas presente no jogo anterior. Essa contradição é o que nos interessa aqui e o que justifica a análise de Final Fantasy $X$ nesta tese.

\section{O Sphere Grid}

Em jogos de RPG como os da série Final Fantasy, personagens evoluem à medida que vão participando de batalhas; vitórias garantem ao jogador um acúmulo de Espólios e também de Pontos de Experiência, os quais são distribuídos às personagens. Quando uma determinada quantia de Pontos de Experiência é acumulada, a personagem evolui e sobe de Nível, garantindo-Ihe melhores Atributos, Pontos de Vida e Pontos de Magia; em geral, personagens podem chegar até o Nível 99 e iniciam sua jornada em um Nível que varia conforme o ponto da narrativa em que entram no grupo: se a personagem está disponível desde o início, ela começará no Nível 1 ou algo próximo disso; caso entre em cena posteriormente, o Nível inicial será ajustado para corresponder aos desafios daquele estágio do jogo.

Em Final Fantasy $X$, esse sistema é radicalmente diferente. Em vez de personagens acumularem Pontos de Experiência e subirem de Nível de acordo com valores pré-determinados, cada personagem ganha a oportunidade de avançar em um tabuleiro e ativar casas para receber acréscimos em seus atributos ou aprender habilidades novas. Há bifurcações que requerem que o jogador avance cada personagem e depois retroceda, e também a possibilidade de sair de um caminho para seguir por outro ao se abrir trancas que criam becos sem saída; mudando radicalmente o

\footnotetext{
${ }^{64}$ Para tornar mais clara a exposição, as personagens masculinas de Final Fantasy $X$ são: Tidus, Wakka, Auron e Kimahri; as femininas são: Yuna, Lulu e Rikku. Kimahri é a única personagem não humana do grupo.
} 
tipo, a frequência e/ou a quantidade de atributos e habilidades encontradas. Essa diferença cria um aspecto de personalização: qualquer personagem pode ser qualquer coisa, desde que o jogador opte por fazer com que determinados caminhos sejam seguidos e outros sejam abandonados, de acordo com o objetivo final.
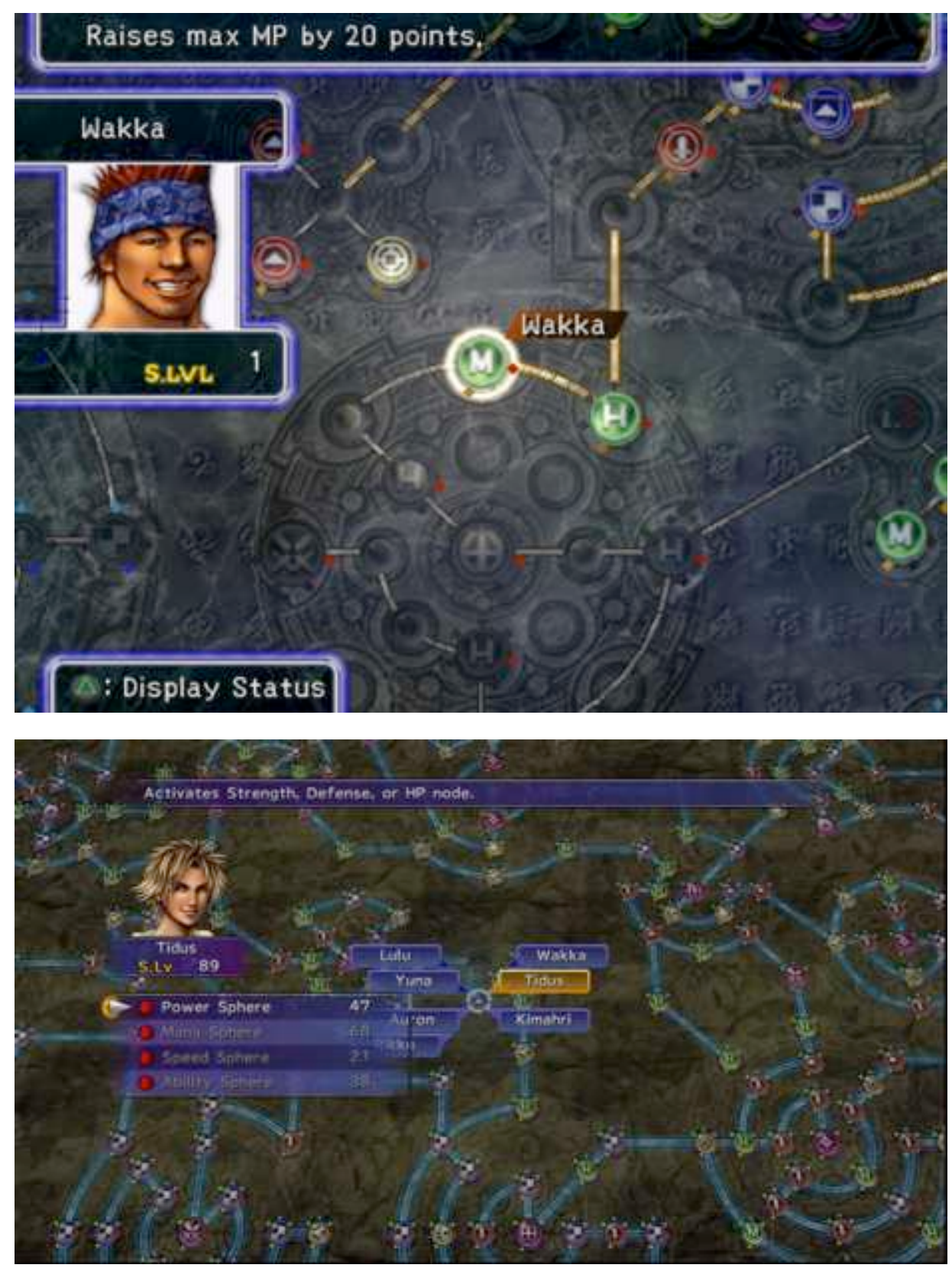

Imagens 30 e 31: O Sphere Grid, em que se pode ver as telas de edição de Wakka e Tidus, com os caminhos percorridos iluminados. (Captura de tela)

À primeira vista, isso cria uma aparência muito grande de variedade e de igualdade entre gêneros, uma vez que personagens femininas ou masculinas dispõem das mesmas casas e podem ser construídas de acordo com o desejo de cada jogador. 
Há, no entanto, diversas restrições importantes que acabam por contradizer a variedade aparente.

A mais evidente delas é a posição inicial de cada personagem no tabuleiro: muito embora haja a possibilidade de que qualquer casa seja atribuída a todas as personagens, cada uma delas começa em um ponto diferente e deve seguir por caminhos distintos para chegar em um mesmo ponto. Yuna inicia seu percurso na rota de curandeira, sem acesso abundante a casas que aumentam atributos de força, ao mesmo tempo em que Auron está próximo de casas cujo foco é o de ataques físicos poderosos, tornando-o um guerreiro apto a golpes diretos; as duas rotas distintas estão em lados opostos do tabuleiro, e para que o jogador consiga inverter os papéis é preciso que vários itens sejam coletados para abrir todas as trancas existentes entre as rotas, além de exigir que várias batalhas extras sejam travadas para aumentar o número de casas percorridas por parte de cada personagem.

Mesmo que o jogador compre a versão atualizada do jogo e ganhe a opção extra de alocar todas as personagens no centro do tabuleiro no início do jogo, ainda assim haverá empecilhos de outra ordem, como a distribuição inicial de atributos e a oferta de equipamentos ao longo do jogo. Yuna tem sua força física e precisão de ataques extremamente reduzidas, embora seja rápida e apta a usar magias; Auron, por sua vez, é o oposto: lento e inepto em termos mágicos, porém forte fisicamente e capaz de atingir seus inimigos com sua espada. Além disso, as armas inicialmente disponíveis para Yuna (cetros) não contêm em sua descrição a característica de Perfuração (Piercing), presente em todas as armas de Auron; isso faz com que ele seja naturalmente capaz de derrotar inimigos encouraçados, enquanto ela se torna inadequada para a tarefa mesmo que 0 jogador faça uso do tabuleiro para aumentar sua força física.

Outro fator que contribui para que jogadores se sintam desmotivados a personalizar as personagens é o fato de o sistema de batalha lembrar bastante o jogo de Pedra, Papel e Tesoura; cada monstro tem um comportamento específico e requer um tipo de estratégia diferente para ser derrotado: lobos são extremamente ágeis e não podem ser atingidos por personagens lentas, o que exclui primariamente Auron, Kimahri e Lulu (a não ser que ela use alguma magia ofensiva); inimigos voadores requerem ataques mágicos ou acertos precisos com armas de longa distância, o que faz com que inicialmente apenas Wakka e Lulu possam atingi-los; inimigos couraçados, como dito, só podem ser atingidos por armas com Perfuração, disponíveis apenas para Auron e 
Kimahri no início do jogo. A lista poderia continuar, mas o sistema é bem claro: é preciso que o jogador se adapte de acordo com cada batalha, substituindo personagens durante o combate de modo a alinhar as especialidades do grupo com o tipo de ataque requerido para enfrentar cada monstro.
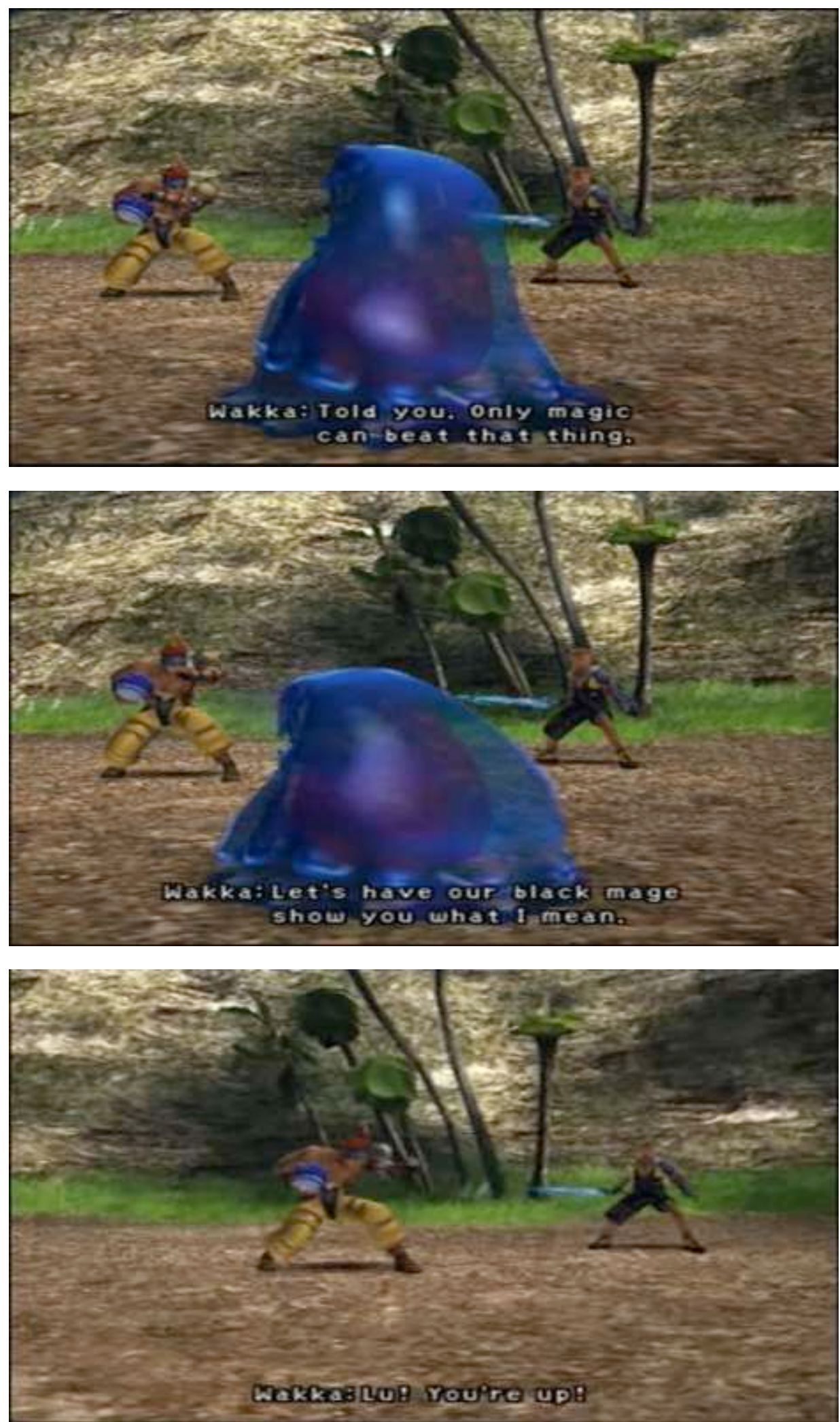


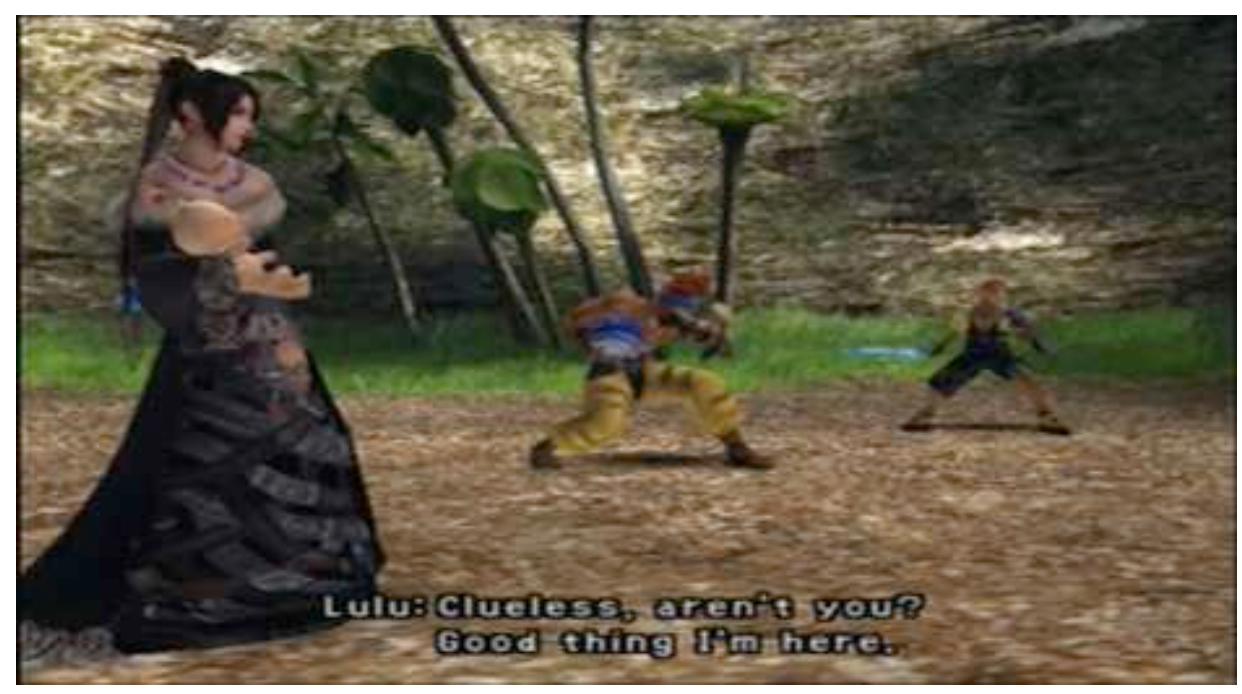

Imagens 32 a 35: Trecho de batalha introdutória em que Lulu é identificada como Maga Negra e o jogador é ensinado a escolher as personagens adequadas para eliminar cada tipo de inimigo. (Captura de tela)

Essa característica gera uma barreira de dificuldade caso o jogador decida personalizar o modo como cada personagem é construída em vez de seguir pelos caminhos pré-determinados, uma vez que há chances de o jogador encontrar uma configuração de batalha que seu grupo não tem como superar sem fazer uso das Evocações de Yuna - as quais substituem o grupo por um dos Aeons disponíveis. O uso dessa estratégia torna o processo de evolução das personagens enfraquecidas mais lento, uma vez que personagens que não agem em batalhas não conseguem avançar no tabuleiro; para forçar a evolução, o jogador teria que selecionar alguma ação tecnicamente inútil com cada uma das personagens enfraquecidas antes de trazer Yuna para o campo de batalha e evocar um Aeon para suprir as falhas estratégicas. Isso torna as batalhas extremamente repetitivas e lentas quando comparadas ao modelo tradicional, em que cada personagem pode ser rapidamente substituída por outra capaz de eliminar inimigos com poucos recursos.

A personalização é, portanto, claramente desencorajada pelas mecânicas de jogo, e faz com que a opção por seguir pelos caminhos pré-determinados do tabuleiro sejam o modelo mais eficaz de jogar. $E$ nesse caso, vemos como os papeis de gênero presentes em Final Fantasy IX aparecem repetidos em Final Fantasy $X$. 


\section{A santa, a sombria e a saliente}

Há três estereótipos básicos em Final Fantasy $X$ representados pelas três personagens femininas. Yuna é contida e doce, como apropriado para uma Maga Branca; Lulu, a Maga Negra, é soturna e ácida; e Rikku, por sua vez, é alegre e tagarela, muito embora seja a Ladra do grupo - especialista em uso de itens especiais e em desativar inimigos mecânicos roubando suas partes.

Suas vestimentas, como visto nas imagens abaixo, refletem suas personalidades, e em diversos pontos do jogo podemos perceber uma espécie de apelo ao lado erótico de cada estereótipo - ou fetiche - representado. Yuna, em sua primeira aparição, está exausta pelo esforço de comunhão com a Fayth - entidades responsáveis pela conexão espiritual de um Evocador com os Aeons - e deve ser amparada por Kimahri para não cair da escada; suas roupas e atitude reforçam sua pureza, força espiritual (em detrimento da física) e gentileza, e a personagem é apresentada em close com a câmera indo dos pés à cabeça.

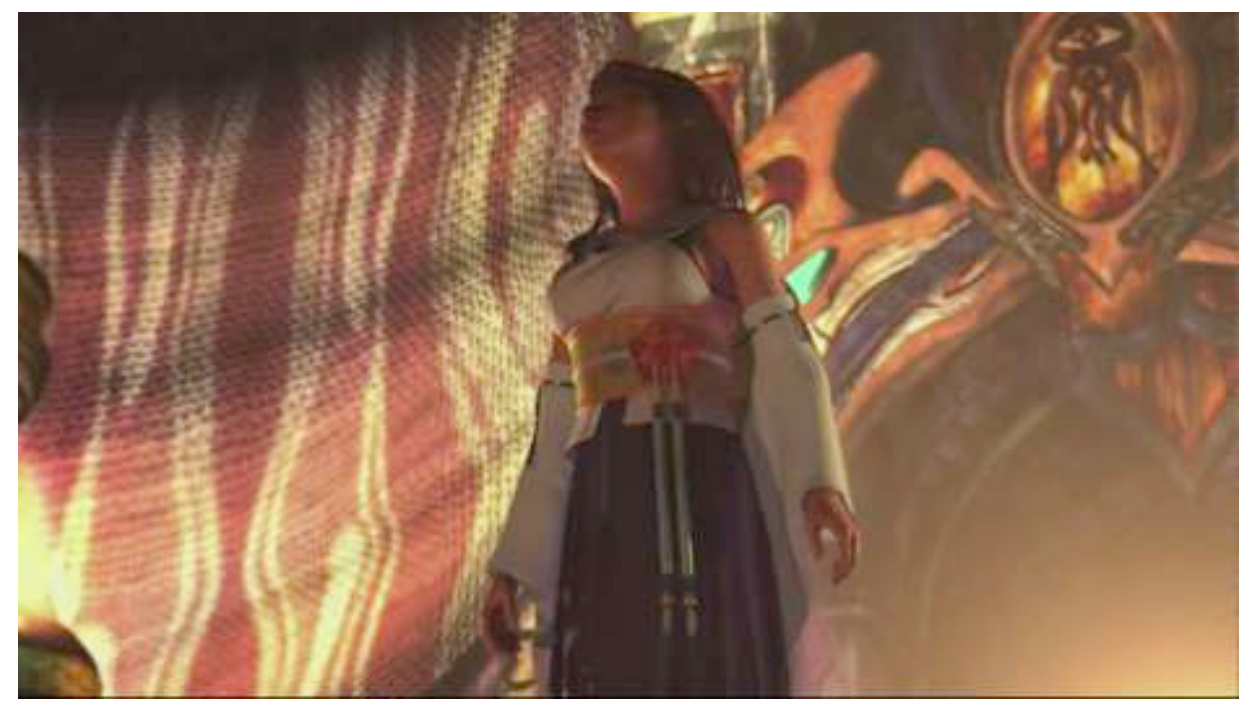

Imagem 36: Yuna em sua primeira cena, exausta e prestes a desmaiar. (Captura de tela) 


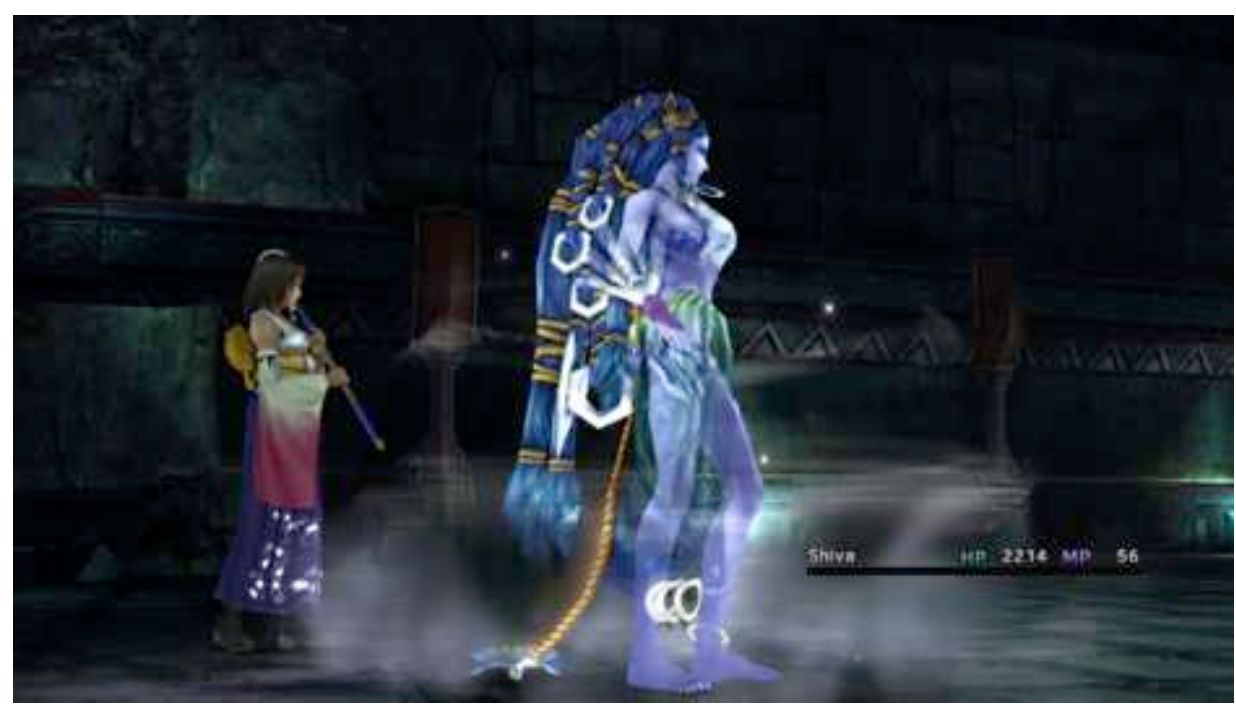

Imagem 37: Yuna em combate, após evocar Shiva. (Captura de tela)

Lulu, por sua vez, é fria, séria e extremamente irritável. Logo no início da jornada, o jogador, sob o ponto de vista de Tidus, presencia uma discussão entre Lulu e Wakka, em que ela o admoesta por trazer Tidus à vila - o que a coloca como a figura materna severa, pronta para colocar os demais na linha, um papel que ela executará ao longo do jogo em diversos pontos da narrativa. A apresentação da personagem feminina segue os moldes anteriores: novamente a câmera em close vai dos pés à cabeça, mostrando os detalhes de sua vestimenta, a qual destoa completamente de todas as demais personagens do jogo e parece extremamente inadequada quando se considera 0 contexto em que ela vive: em uma ilha aparentemente tropical, Lulu usa um vestido preto com tiras de couro cobrindo a abertura na saia - larga o suficiente para mostrar as pernas - e uma espécie de penugem na altura dos ombros. O decote, bastante pronunciado, é também destacado na cena, e reforçado ao longo de todo o jogo na posição de vitória de Lulu após uma batalha: ela se inclina para a frente de modo a mostrar o máximo possível. 


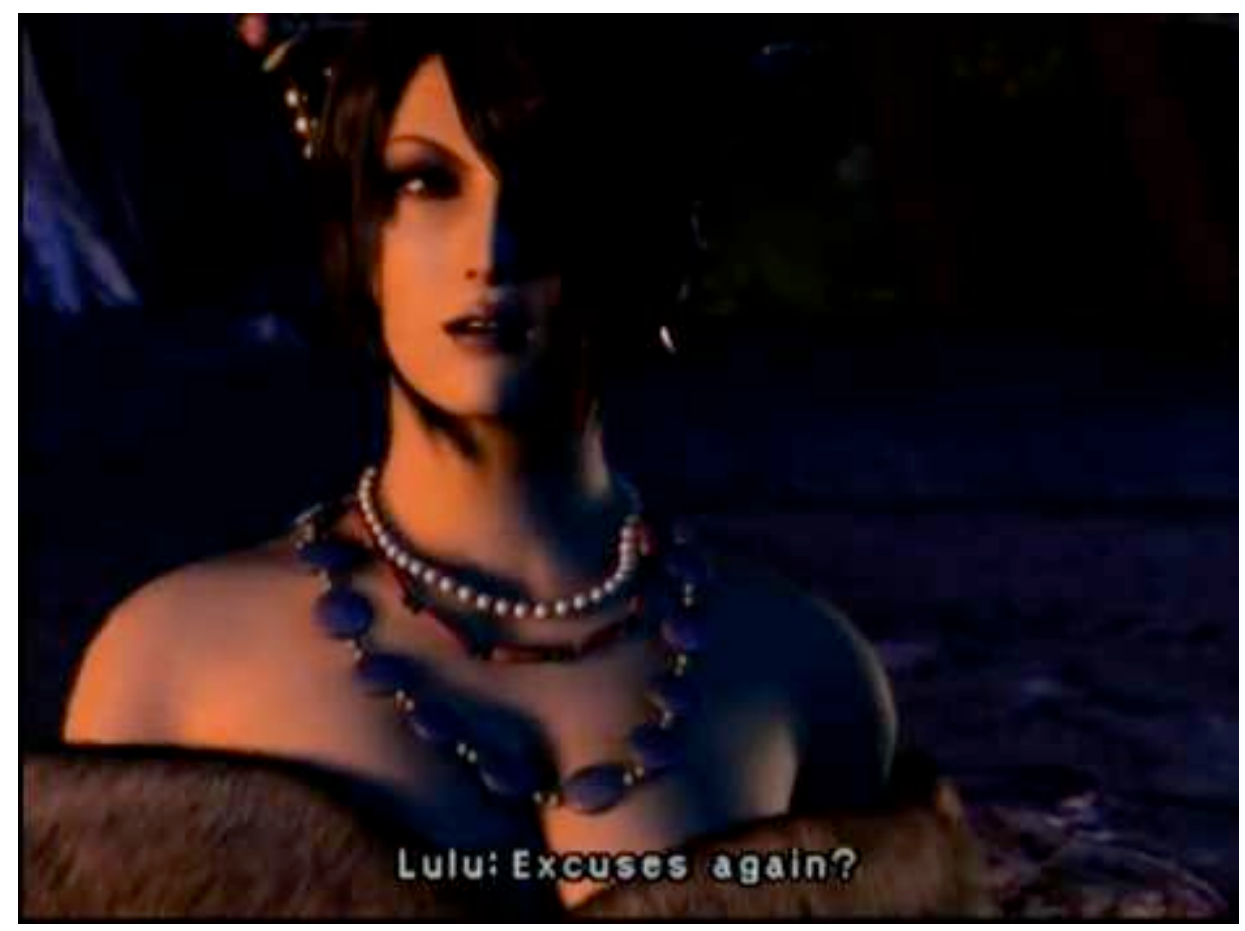

Imagem 38: Lulu em sua primeira cena, discutindo com Wakka. (Captura de tela)

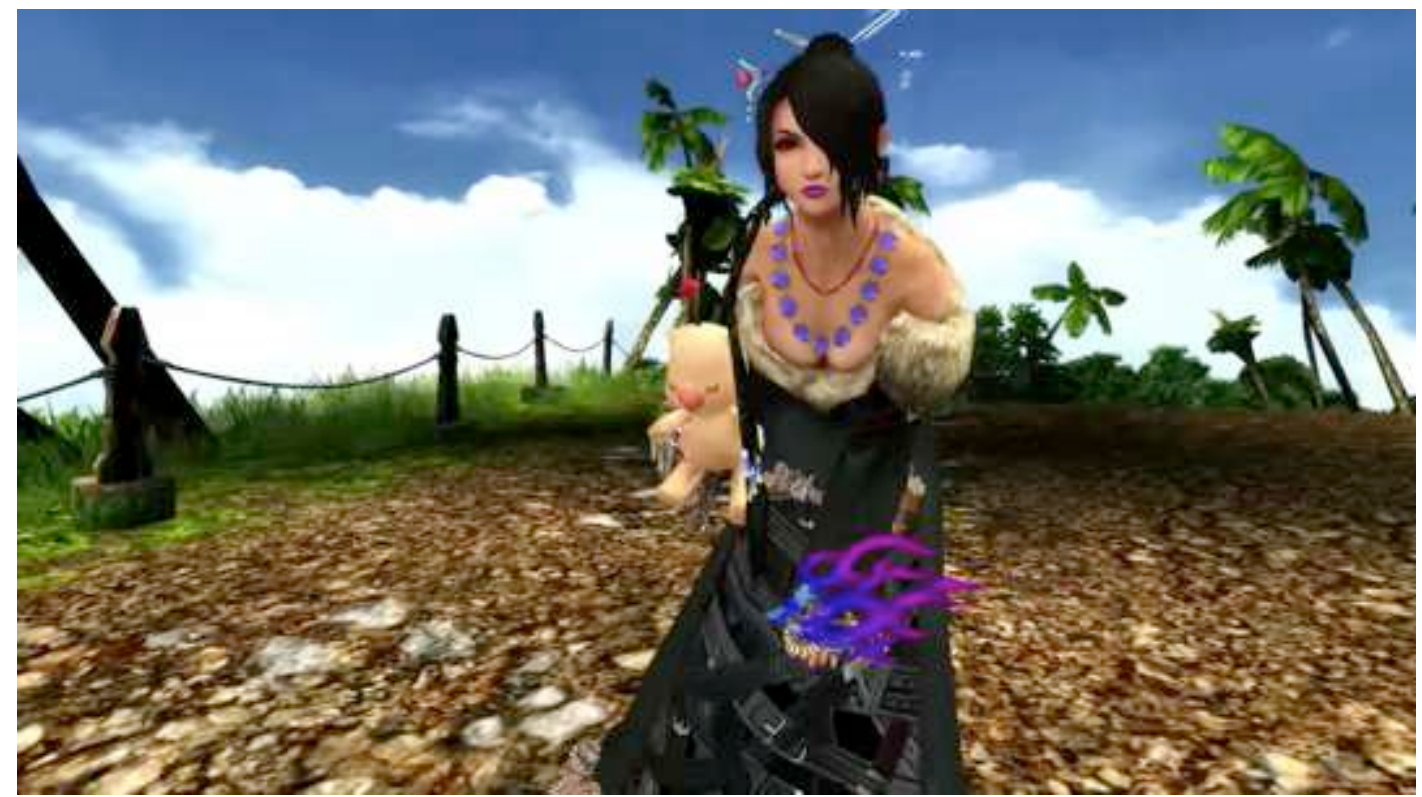

Imagem 39: Pose de vitória de Lulu após combates. (Captura de tela)

Por fim, Rikku usa roupas com cores mais vibrantes e mostra o máximo possível do corpo. Sua cena de introdução, como ocorre com Yuna e Lulu, é feita em close, mas, diferente do que ocorre com as personagens mais "contidas", é baseada em stripping: Rikku aparece se desvencilhando de um traje de mergulho que a recobre, e revela a vestimenta que usará ao longo do jogo - uma camiseta sem mangas, shorts curtos e uma bota que vai até a metade da canela. O traseiro da personagem é destacado na cena, o que vai ao encontro do tratamento dado a Lulu, cujo foco recai nos seios. 

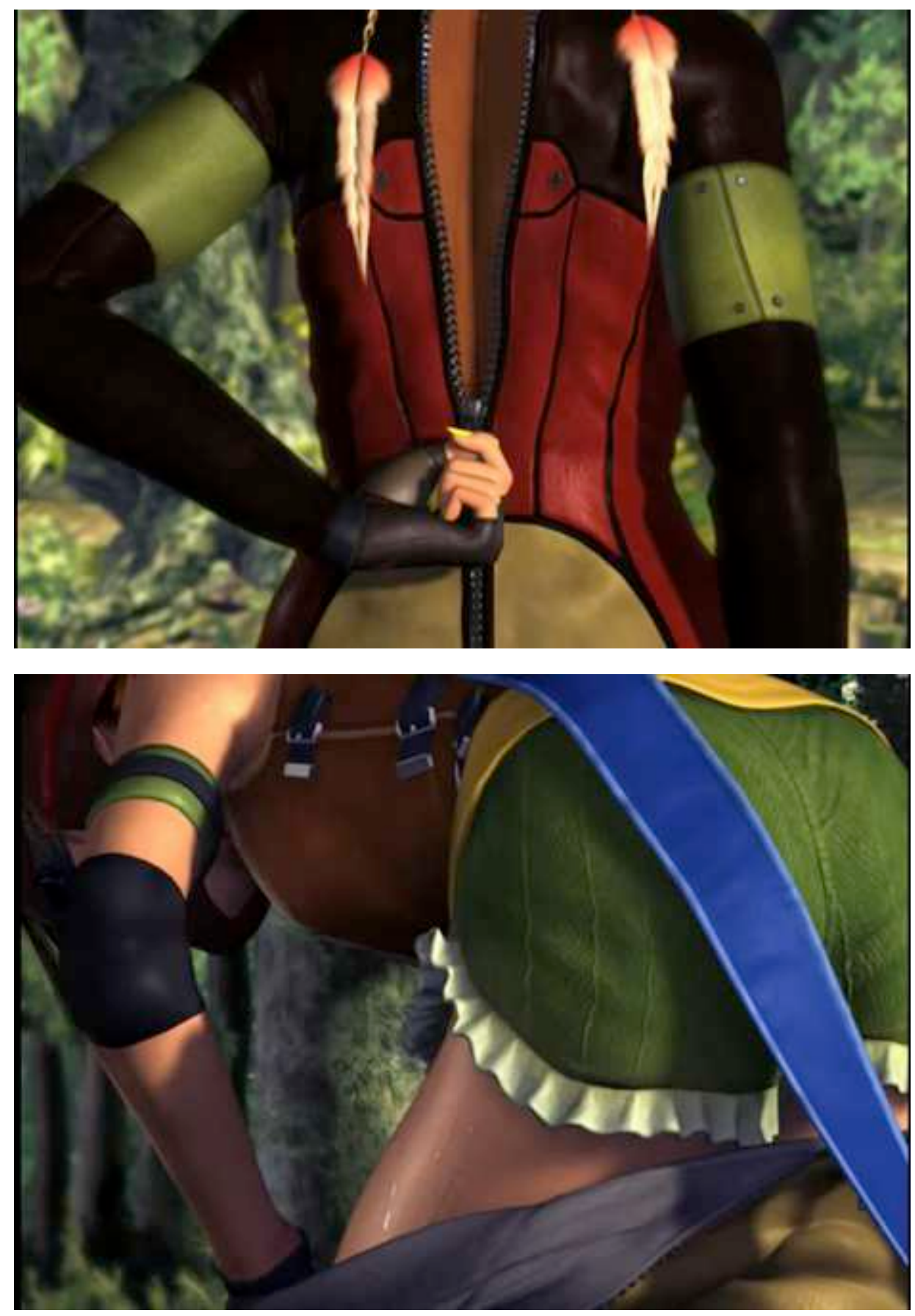

Imagens 40 e 41: Rikku despindo-se de seu traje de mergulho. (Captura de tela)

O contraste entre a apresentação das personagens femininas e masculinas é evidente quando observamos a cena introdutória de Kimahri: ele surge repentinamente, saltando de um pilar ao outro, em posição de combate, rosnando para Tidus; seus músculos tremem e ficam tensos enquanto ele arranha o chão e em seguida o esmurra. Não há foco nos glúteos ou em qualquer outra parte do corpo que possa ser alvo de um fetiche; apenas uma demonstração de força bruta e instinto protetor, uma vez que o jogador é forçado a combatê-lo logo em seguida e, ao fim da batalha, descobre que se 
trata apenas de uma estratégia de intimidação: como protetor de Yuna, Kimahri quer mostrar a Tidus que não irá tolerar qualquer ameaça a ela.

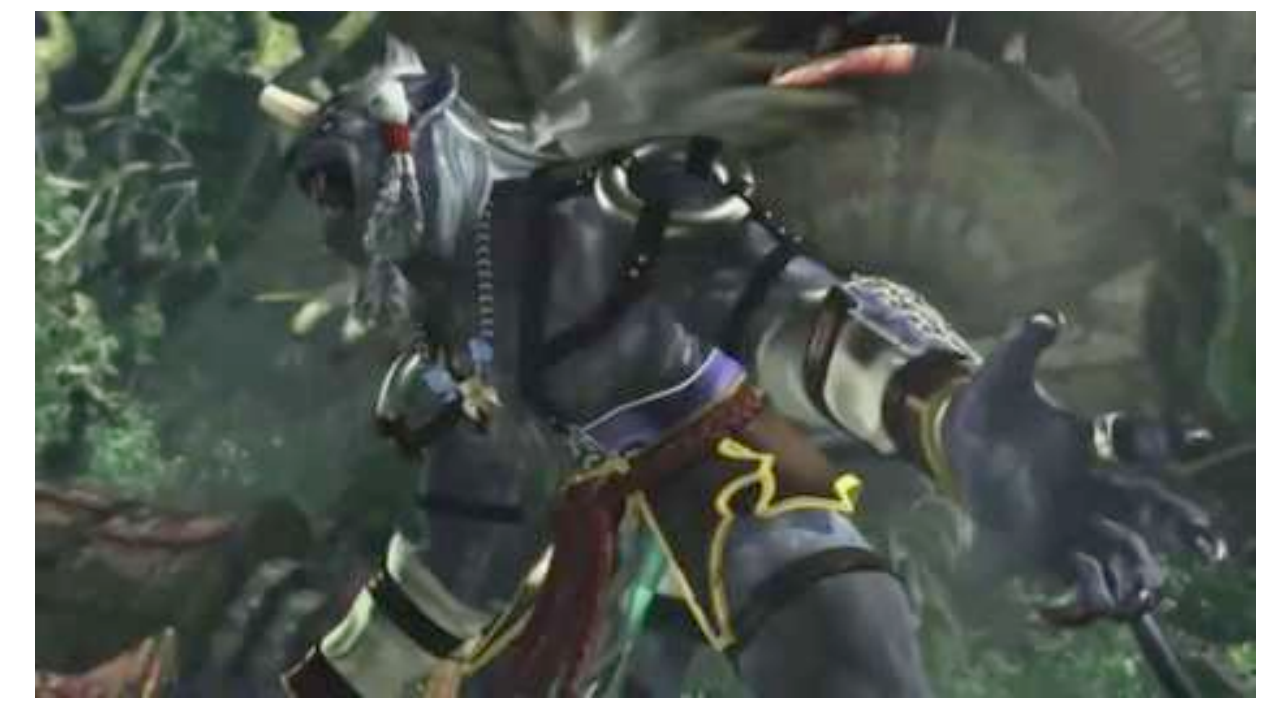

Imagem 42: Kimahri em pose intimidatória durante sua introdutória. (Captura de tela)

Nota-se, portanto, que há uma clara distinção entre o tratamento dado a personagens: as masculinas têm sua força e vigor exaltados tanto nas cenas introdutórias quanto nas mecânicas de jogo; as femininas são apresentadas como frágeis, delicadas e sexy, dotadas seja de uma grande força interior, seja de destreza e agilidade superiores. O padrão de Final Fantasy IX é aqui repetido, e o modo como os estereótipos se encaixam coloca em xeque a ideia de que se trata de mera coincidência.

\section{Hierarquias linguísticas}

A repetição de padrões também pode ser notada no tratamento linguístico das personagens, para além do que é colocado de modo aparente no enredo. Em Final Fantasy $X$, um dos conflitos principais se desenvolve entre os seguidores de Yevon, o grupo religioso dominante, e os Al Bhed, um povo que considera as tradições de Yevon abomináveis e faz uso de maquinário proibido pela liturgia; ambos têm como objetivo a destruição de Sin, o monstro que assola o mundo de Spira, mas enquanto Yevon perpetua os rituais de sacrifício de Evocadores, os Al Bhed acreditam que há outras maneiras. Por não seguirem as tradições, os Al Bhed são um povo que vive no 
ostracismo e é alvo constante de preconceitos e ataques por parte de Yevon - no decorrer do jogo, a ilha onde vivem é destruída.

No jogo, um Al Bhed é reconhecido por duas características: os olhos verdes e o idioma Al Bhed, que consiste basicamente em uma versão embaralhada da língua inglesa; letras e sons são simplesmente trocados de lugar, mantendo sintaxe e semântica intactas. O jogador "aprende" Al Bhed ao longo do jogo por meio de dicionários coletáveis que substituem as letras das legendas pelas correspondentes em inglês. Não se trata, evidentemente, de um idioma novo, e sim pura e simplesmente de uma tentativa bastante engenhosa de criar uma variedade linguística no mundo de Spira que ilustre a separação total entre povos; o tema de desconfiança é, portanto, trabalhado sob o viés da incomunicabilidade total. Esse é o conteúdo aparente: uma minoria que sofre por ostracismo e é vista com desconfiança, em parte por falar um idioma diferente; há, no entanto, uma repetição - menos óbvia - dos padrões apresentados em Final Fantasy IX.

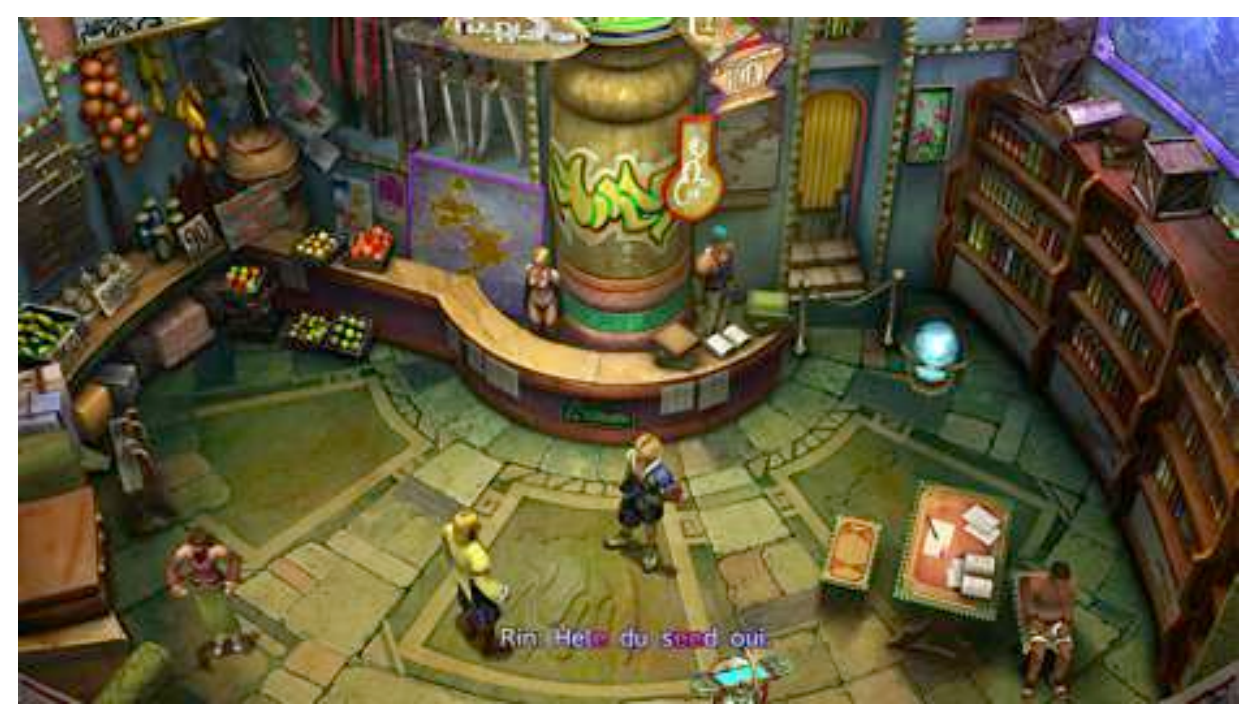

Imagem 43: A frase "Nice to meet you" em Al Bhed. Os caracteres em vermelho são os já aprendidos pelo jogador. (Captura de tela)

Dentre elas, a mais fácil de observar talvez seja o tratamento dado aos Ronso, a tribo de seres felinos a que Kimahri pertence. Não há qualquer indício no jogo de que eles façam uso de uma língua própria, e sua comunicação é feita por meio de uma versão extremamente simplificada de inglês, muito próxima ao de Quina em Final Fantasy IX - há pouco uso de pronomes, nem uso (extenso) de subordinação ou coordenação de sentenças, e outros aspectos que um falante "qualificado" do idioma deveria (saber) usar. É também interessante constatar que Kimahri é a versão de Final Fantasy $X$ de Mago 
Azul, a mesma classe a que pertence Quina: ele é capaz de aprender habilidades de monstros ao sugar sua energia com a técnica Lancet; embora qualquer personagem possa utilizá-la, apenas Kimahri irá absorver o conhecimento do inimigo.

Há, portanto, uma aproximação entre a figura do Mago Azul, tanto em Final Fantasy IX quando em Final Fantasy $X$, e o aspecto da bestialidade, traço que se revela isotopicamente pela inaptidão em língua inglesa. Como dito anteriormente, isso se torna problemático quando relacionado ao fato de que jogadores cujo nível de proficiência em língua inglesa é baixo acabam aproximados dessas personagens. Não se trata, evidentemente, de uma relação intencional feita pelos desenvolvedores como uma forma de preconceito contra não-falantes de inglês; no entanto, em um contexto global que coloca línguas como inglês, francês e alemão em uma hierarquia superior a outras como "línguas de cultura", pertencentes a povos superiores intelectualmente aos demais, essa relação inadvertida é perigosa - sobretudo quando, no enredo do jogo, os Ronso são caracterizados como seres de inteligência inferior aos demais.

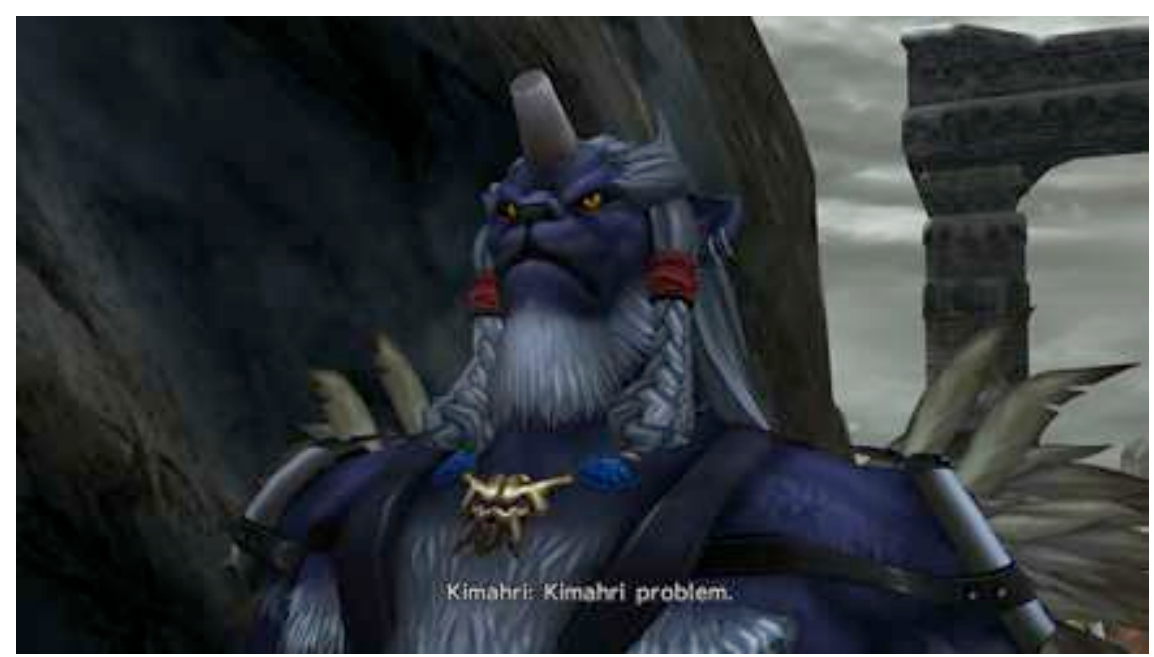




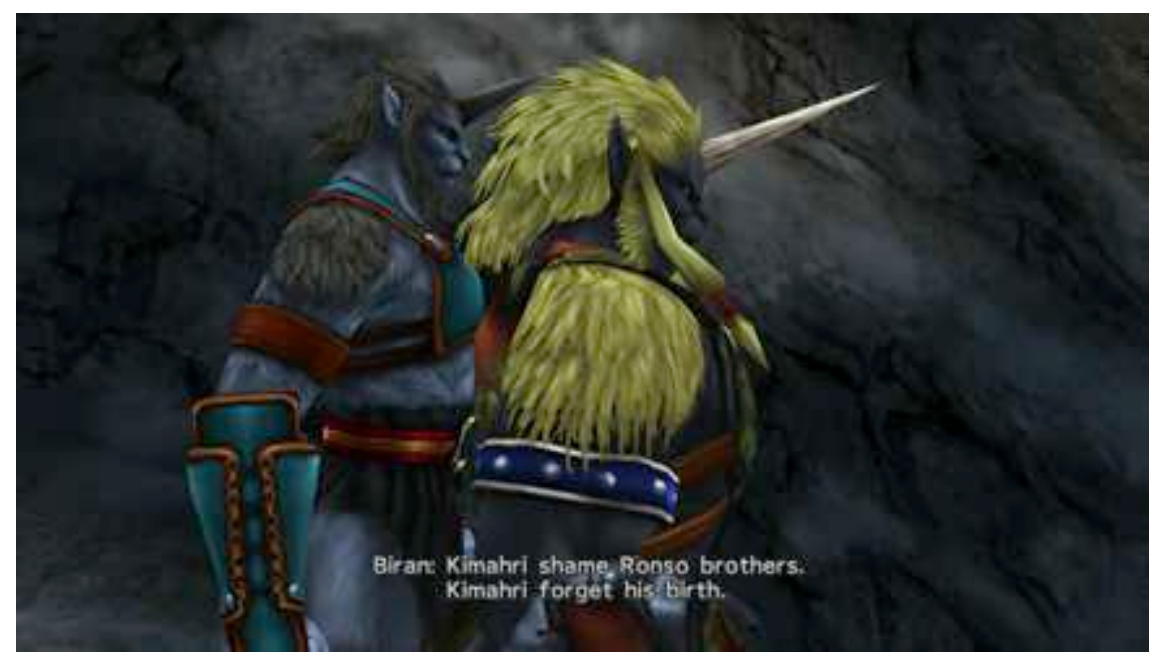

Imagem 44 e 45: Trechos de um diálogo entre membros da tribo Ronso e Kimahri. Nota-se falta de concordância e de uso de pronomes possessivos ou do genitivo. (Captura de tela)

Há, no entanto, mais exemplos em Final Fantasy X. Os Hypello, seres nãohumanos pouco presentes no jogo que têm como função conduzir os shoopufs (uma espécie de elefante), também demonstram pouca aptidão na língua inglesa. Porém, o mais marcante dos exemplos, e talvez o menos óbvio, é o de Wakka e dos demais jogadores de Blitzball da ilha de Besaid: vistos como menos inteligentes que seus pares, são as únicas personagens do jogo que apresentam um sotaque bastante definido - uma espécie de inglês insular/tropical. Wakka é visto como o cabeça dura, pouco capaz de perceber coisas óbvias diante de si: ele é o único membro do grupo que não percebe que Rikku é uma Al Bhed, e é aquele que segue, sem questionar, todos os ensinamentos de Yevon. Para além da questão linguística, há também o fato de que Wakka e os demais membros do time de Blitzball têm uma tonalidade de pele mais escura - ou seja, nãobrancos.

Embora não haja nenhuma menção explícita, é bastante curiosa, para dizer o mínimo, a coincidência de lugares-comuns e estereótipos alinhados na construção dessas personagens: cor da pele, local de origem, sotaque - todas elas características utilizadas em argumentos racistas para hierarquização étnica. Argumentamos que é a partir desse tipo de relação repetida em diversos jogos que surge a cultura de preconceito e segregação entre jogadores que se verifica nos jogos online, como veremos a seguir. 


\section{Overwatch}

Overwatch (Blizzard, 2016-presente) é um jogo classificado como MOBA (Multiplayer Online Battle Arena) e consiste em colocar em conflito dois times compostos por seis jogadores cada. Os objetivos variam de acordo com cada mapa de jogo, mas o núcleo de todos eles é bastante simples: trata-se de uma briga por dominância, seja na forma de uma área que precisa ser conquistada ou de uma carga a ser escoltada; um time deverá atacar enquanto o outro defende, alternando entre rodadas para definir o vencedor no modelo "melhor de três" ou "melhor de cinco".
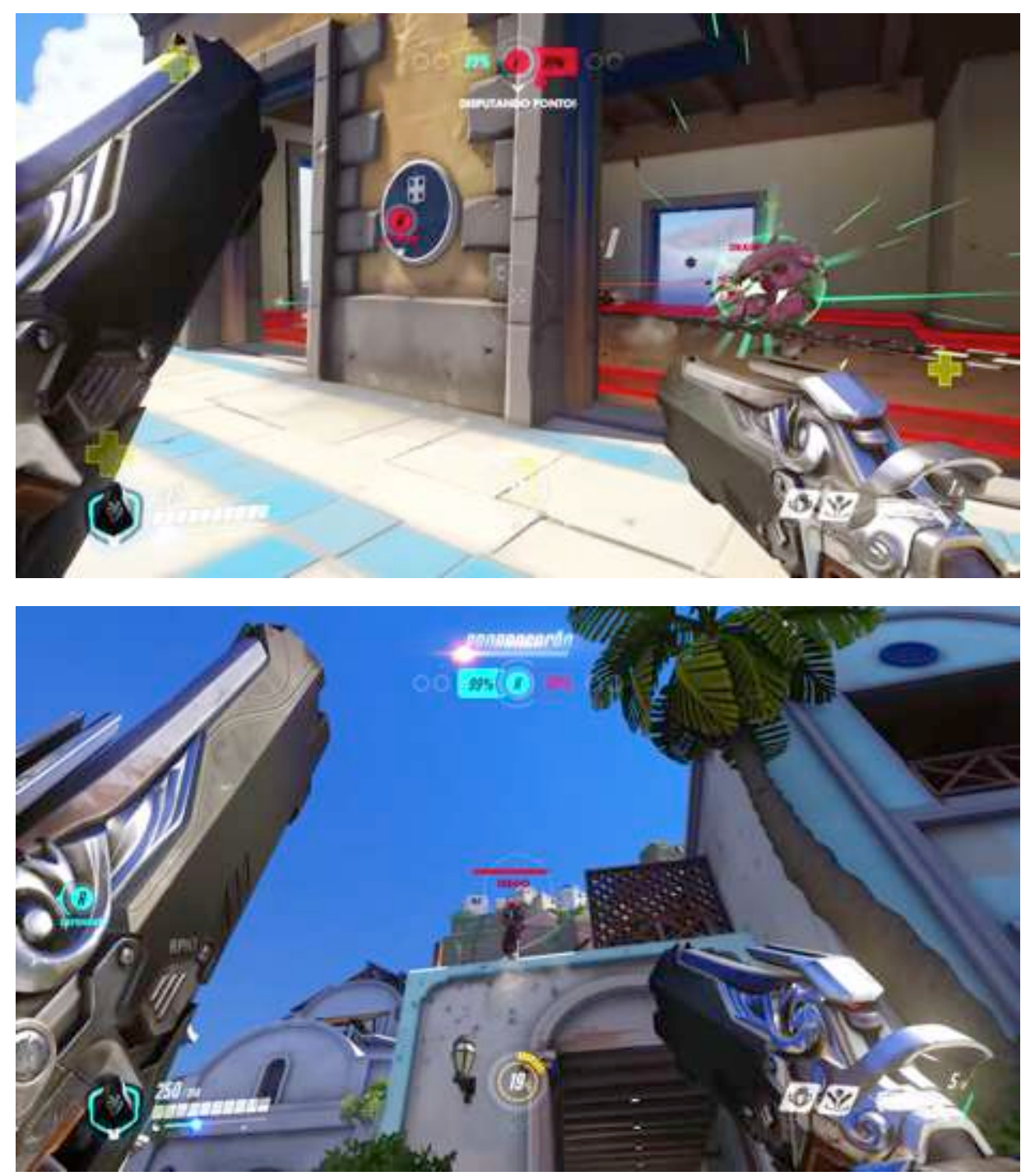

Imagens 46 e 47: Trechos de uma partida de Overwatch. Jogadores disputam a dominância de um ponto do mapa. (Captura de tela) 
Embora não seja um RPG e sim um FPS (First Person Shooter), Overwatch apresenta um sistema baseado em classes; cada uma das 30 personagens é classificada de acordo com o tipo de habilidades que apresenta, podendo desempenhar os papeis de Dano, Tanque ou Suporte. Algumas personagens são híbridas, com habilidades que podem ser classificadas em mais de um papel ou que, quando utilizadas de modo inteligente, contribuem em outros campos - Zenyatta, por exemplo, é uma personagem de Suporte que é capaz de deslanchar ataques extremamente poderosos, pendendo para o lado mais ofensivo do espectro dentre os suportes disponíveis; Mercy, por sua vez, é extremamente limitada ofensivamente, ocupando o posto de um Suporte "puro". Sendo assim, é possível, assim como nos RPGs, traçar relações isotópicas entre estereótipos de gênero e jogabilidade.

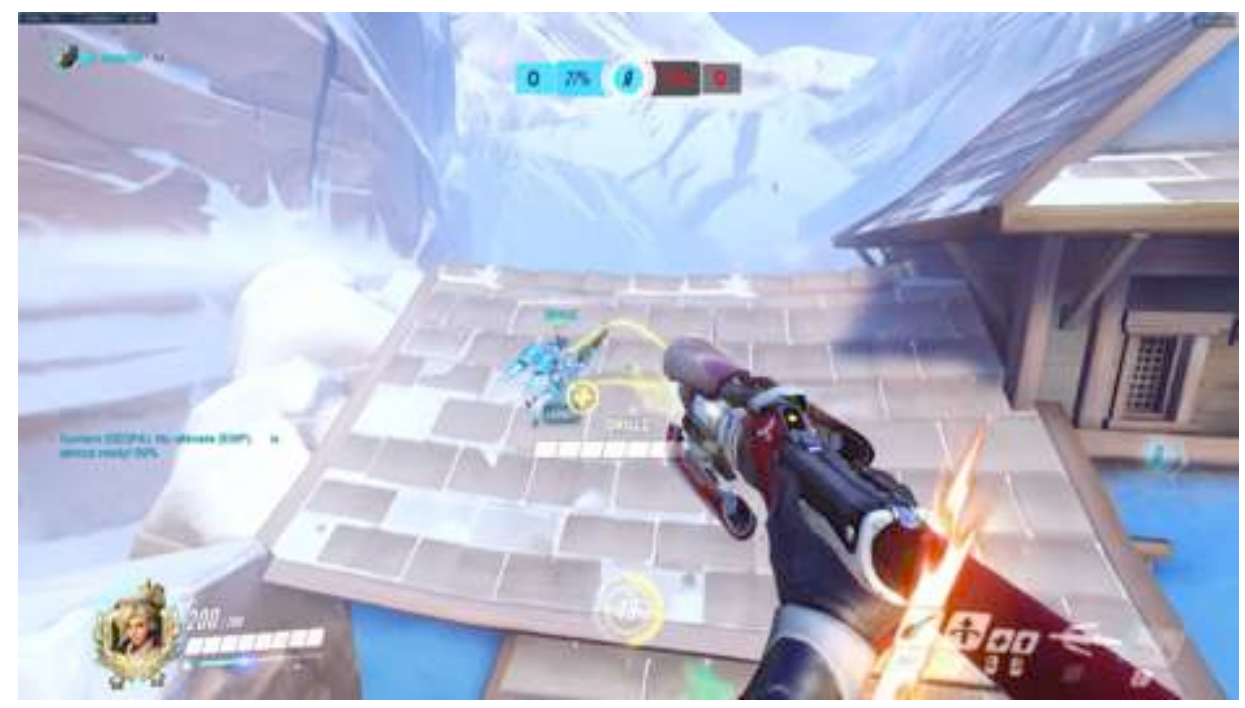

Imagem 48: Mercy curando um de seus companheiros de equipe. (Captura de tela)

Overwatch, no entanto, apresenta mais uma camada na construção narrativa de suas personagens: nacionalidade. Com um enredo de pano de fundo que ocorre na Terra em uma espécie de futuro distópico, as diversas personagens apresentam características que as ancoram, de certa forma, no que se espera de participantes de organizações supra-nacionais como são a Overwatch e, sua inimiga, a Talon - todas as personagens vêm de um lugar diferente, e suas trajetórias e histórias de base formam um sistema narrativo coeso, o qual também se reflete em sua jogabilidade. 
D.Va, por exemplo, é uma gamer profissional que, por seus reflexos rápidos e capacidade de manusear controles mecânicos, foi recrutada pelo governo da Coreia do Sul durante a Crise Ômnica ${ }^{65}$ para comandar mechas - uma espécie de armadura mecânica equipada com diversas armas. No jogo, D.Va atua como Tanque, comandando seu mecha no campo de batalha para receber a maior parte do impacto dos ataques do time adversário; dentre suas habilidades, está a auto-destruição do mecha - que elimina qualquer inimigo na zona de impacto da explosão - e a possibilidade de chamar um mecha novo caso ele seja destruído pelo inimigo; quando isso ocorre, D.Va fica desprotegida e passa a ter o mesmo potencial ofensivo e defensivo de Mercy - capaz apenas de atirar com uma pistola de plasma simples, sem quaisquer outras habilidades até que tempo suficiente se passe para que o mecha substituto fique pronto.

Roadhog, por sua vez, é um homem de nacionalidade desconhecida que atua como guarda-costas do comandante de um grupo anarquista australiano, cujo único objetivo é assassinar opositores e saquear o máximo de locais possíveis no sertão da Austrália. Diferente de D.Va, o potencial de Tanque de Roadhog não depende de absolutamente nada mecânico ou especial: trata-se de um homem gordo que perambula sem camisa pelo campo de batalha, puxando membros da equipe inimiga para perto de si com um gancho de modo a exterminá-los com sua espingarda de detritos. Quando atingido muitas vezes, Roadhog pode recuperar Pontos de Vida por meio de um medicamento injetado em sua máscara, garantindo que ele possa resistir no campo de batalha por longos períodos de tempo sem a necessidade de retroceder para a retaguarda ou para a base.

\footnotetext{
${ }^{65}$ A Crise Ômnica é um evento da história de fundo de Overwatch que consiste na guerra entre humanos e robôs senscientes.
} 


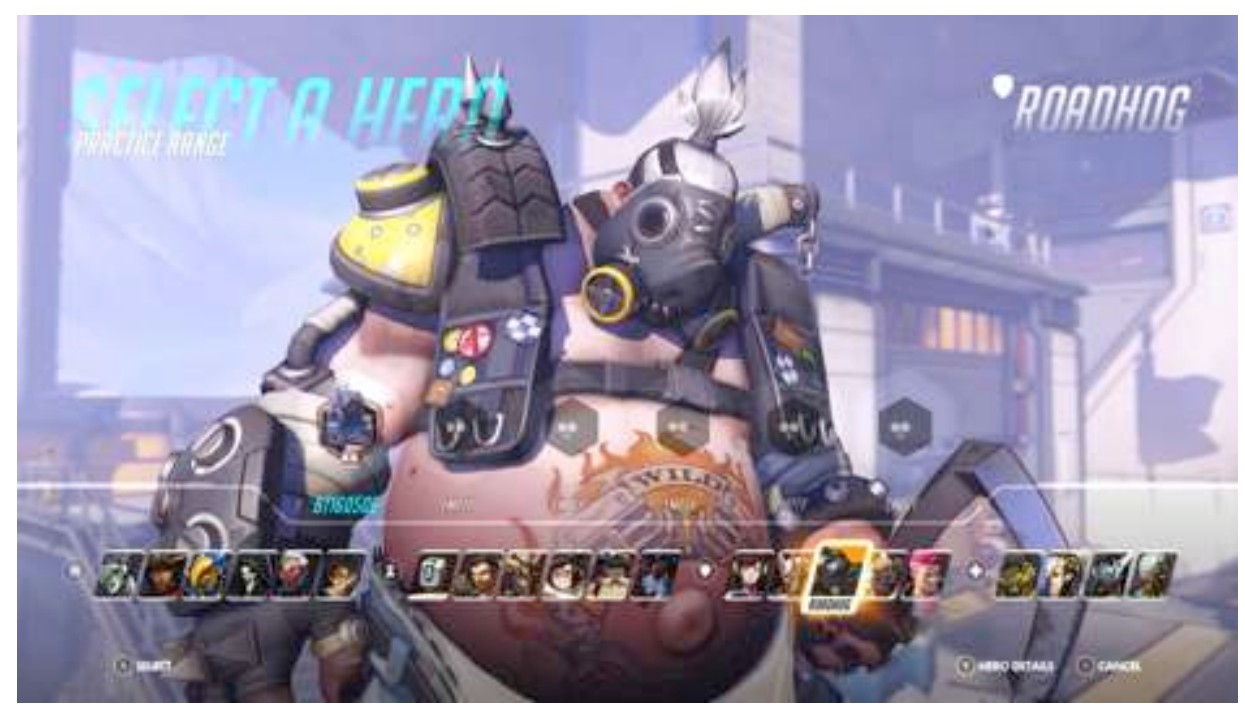

Imagem 49: Roadhog na tela de seleção de personagens à época do lançamento do jogo. (Captura de tela)

Nota-se, portanto, que D.Va tem sua jogabilidade alinhada com o estereótipo da garota do sudeste asiático: frágil fisicamente, mas capaz de manipular a tecnologia a seu favor. Esse tema será repetido em outras personagens, como Genji, Mei, Hanzo e Symmetra, todas elas consideradas como personagens de Dano, os quais fazem uso de tecnologia para desempenhar seus papeis.

Genji é um ninja japonês cujo corpo mutilado foi bionicamente aprimorado com partes robóticas; ele é extremamente ágil e também é capaz de escalar paredes, podendo transitar pelo campo de batalha muitas vezes sem ser notado e eliminar membros da equipe inimiga rapidamente com ataques surpresa, além de ser extremamente proficiente em retirar-se da linha de tiro acessando partes da arena a que outras personagens não são capazes de chegar.

Mei é uma cientista chinesa que utiliza criogenia para criar barreiras de gelo, congelar inimigos ou encapsular-se em uma cápsula congelada para ficar imune a ataques inimigos e recuperar pontos de vida; ela é resistente e capaz de proteger áreas praticamente sozinha caso o jogador faça uso inteligente de seus aparatos tecnológicos. Mei pode ser considerada um herói híbrido entre Dano e Tanque devido a seu potencial defensivo, porém ela é mais frágil que qualquer um dos demais Tanques do jogo exceto D.Va, quando fora de seu mecha; antes da reorganização dos grupos de personagens, Mei era classificada como um herói Defensivo.

Hanzo, por sua vez, é um atirador de elite japonês, capaz de escalar paredes (assim como Genji) e garantir sua posição em pontos elevados do mapa, para eliminar inimigos com tiros certeiros de seu arco e suas flechas mecânicas, as quais podem 
explodir em diversos detritos ou criar uma espécie de sonar para revelar a localização de membros da equipe adversária; trata-se de uma personagem sorrateira que se mantém afastada da linha de tiro para isolar inimigos e eliminá-los silenciosamente, ao mesmo tempo em que usa tecnologia para dar suporte ao grupo.

Symmetra, por fim, é uma arquiteta indiana que usa fótons para manipular matéria e criar diversas armadilhas e artefatos para atrapalhar o time adversário e melhorar a performance de sua equipe: raios laser que podem ser acoplados em paredes para atacar inimigos que se aproximarem, geradores de escudo, pontos de teletransporte Symmetra é capaz de isolar inimigos e criar barreiras extremamente poderosas contra uma invasão do time adversário. Antes de ser realocada para a categoria Dano, Symmetra era considerada uma personagem de Suporte devido a seu alto potencial defensivo e sua posição preferencial na retaguarda do campo de batalha.

Seja como for, nota-se que existe uma espécie de tema que coloca as personagens asiáticas em um grupo extremamente focado em uso de subterfúgios para conseguir seus objetivos, em um contraste bastante claro com outros estereótipos. Doomfist, por exemplo, é nigeriano e é um herói de Dano que foca em ataques corpo a corpo, lançando-se no campo de batalha com pouco ou nenhum tipo de defesa; Lúcio e Baptiste, heróis de Suporte, são também negros (brasileiro e haitiano, respectivamente) e também pendem para um estilo mais agressivo mesmo dentro do espectro de personagens de Suporte, uma vez que são capazes de curar e causar dano ao mesmo tempo (assim como Zenyatta, mencionado anteriormente). Essa característica é inusitada quando se verifica que o grupo de Suporte é dominado majoritariamente por personagens femininas cujo potencial ofensivo é, em certos aspectos, mais limitados ou menos evidentes: Mercy, como dito anteriormente, tem quase nenhum potencial ofensivo, enquanto Moira e Ana, embora possam curar e causar dano aos inimigos mais facilmente, ainda encontram algumas barreiras de recursos ou determinadas escolhas a fazer: Ana tem munição limitada em seu rifle biótico de longa distância, e deve escolher entre curar (atingindo um aliado) ou causar dano (atingindo um inimigo); Baptiste, por sua vez, tem munições separadas para dano e cura, e pode alternar entre tiros rapidamente.

O que nos interessa aqui não é, necessariamente, o potencial de dano direto ou indireto de cada personagem em termos puramente matemáticos, mas a conexão isotópica entre jogabilidade e construção temático-figurativa. No caso, os orientais que "abusam" da tecnologia - muito embora todas as personagens usem artefatos de ponta 
- ou os negros que, diferente de Mercy, a médica suíça, não ocupam uma posição "passiva" mesmo sendo suportes. Vê-se, portanto, que mesmo Overwatch apresentando um conjunto bastante diverso de personagens em termos de gênero, tipos de corpo e nacionalidades, ainda há (em partes, ao menos) o alinhamento entre estereótipos e papeis de gênero verificados nos jogos offline analisados; há, no entanto, uma consequência maior em Overwatch: a interação entre jogadores causa problemas derivados das concepções de gênero e de hierarquia étnica, como verificaremos adiante.

\section{Um clube restrito}

A comunidade gamer, como visto anteriormente na tese, não é um grupo inclusivo; a GamerGate e seu ódio às mulheres e outras minorias são reflexo de uma cultura machista que domina a indústria, o qual também pode ser visto no alinhamento de estereótipos com o design de personagens e suas classes. Se em um jogo offline o jogador tem total liberdade para ignorar essas imposições e jogar da maneira como bem entender, em jogos online a interação se torna um fator imposto e a fuga das imposições - sejam pela via do meta-jogo ou dos discursos de ódio - implica em ostracismo ou na desistência absoluta do jogo.

Exemplo disso é o caso de 2017, relatado em matéria online da revista Capricho ${ }^{66}$, em que um pai entra em contato via rede social com a comunidade de jogadores de Overwatch pedindo para que parem de assediar sua filha de 10 anos. Segundo o relato, toda vez que a menina tentava jogar e utilizava o sistema de chat de voz - única forma realmente eficiente de contato com outros membros da equipe -, ela era recebida com xingamentos e era vítima de assédio (pedidos de fotos etc.).

Esse tipo de comportamento pode parecer à primeira vista algo desvinculado do jogo em si, uma vez que os desenvolvedores não são responsáveis pelo comportamento de qualquer pessoa que venha a consumir seu produto; no entanto, há especulação dentro da comunidade de jogadores a respeito de um fato curioso no desenvolvimento da personagem D.Va: ela era, em seu conceito original, uma garota menor de idade, mas na versão final é uma mulher de 19 anos. A justificativa de que ela pareceria menos

\footnotetext{
${ }^{66}$ https://capricho.abril.com.br/vida-real/overwatch-pai-pede-que-gamers-parem-de-assediar-filha-de-10anos/ (Acesso em Julho de 2019)
} 
intimidadora sendo mais nova é motivo de piada e questionamentos em foruns online, cujos membros suspeitam que a mudança foi motivada por algo completamente diferente - no caso, a produção de conteúdo pornográfico por jogadores. ${ }^{67}$ Esse tipo de decisão não é incomum na indústria de jogos recentemente em uma entrevista, o produtor Naoki Yoshida (responsável por Final Fantasy XIV) afirmou que há uma impossibilidade ética em permitir que jogadores criem personagens infantis, uma vez que não há como controlar o uso dos recursos de captura de tela do jogo ou as interações entre jogadores feitas no mundo aberto de Final Fantasy XIV, e o mau uso desses recursos poderia causar, no futuro, uma interrupção do serviço. ${ }^{68}$

Há, portanto, uma preocupação ativa por parte dos desenvolvedores de jogos no que diz respeito ao uso ilegal de seu material - no caso, pornografia infantil. No entanto, é bastante curioso que, no que toca o design da personagem D.Va em Overwatch, que a empresa Blizzard possa ter escolhido simplesmente aumentar a idade da personagem para que ela pudesse ser utilizada em conteúdo pornográfico em vez de remodelar sua aparência de modo a gerar desinteresse nesse tipo de uso. Evidentemente, a real motivação por trás da decisão em modificar a idade de D.Va não pode ser definida e a questão da sexualização da personagem é meramente especulativa. No entanto, é bastante sintomático o fato de que as personagens femininas em Overwatch (e em diversos outros jogos presentes no mercado) são modeladas digitalmente de acordo com um padrão de corpo atraente para o público masculino. Sendo assim, parece-nos bastante evidente a relação entre o assédio sofrido por jogadoras, a cultura machista dominante na indústria e as escolhas de design feitas pelos desenvolvedores - um sistema de motivações indiretas, retroalimentativo e que está presente desde a representação figurativa das personagens até os elementos mecânicos de sua jogabilidade.

\footnotetext{
${ }^{67}$ Cf. discussão em https://us.battle.net/forums/en/overwatch/topic/20759328855?page=3 e o meme em https://www.reddit.com/r/Overwatch_Memes/comments/72rqxf/originally_the_devs_were_gonna_make_dv a_16_years/ (Acesso em Julho de 2019)

${ }^{68}$ http://www.novacrystallis.com/2019/05/naoki-yoshida-addresses-gender-locked-races-dancer-dpsproducer-letter/ (Acesso em Julho de 2019)
} 

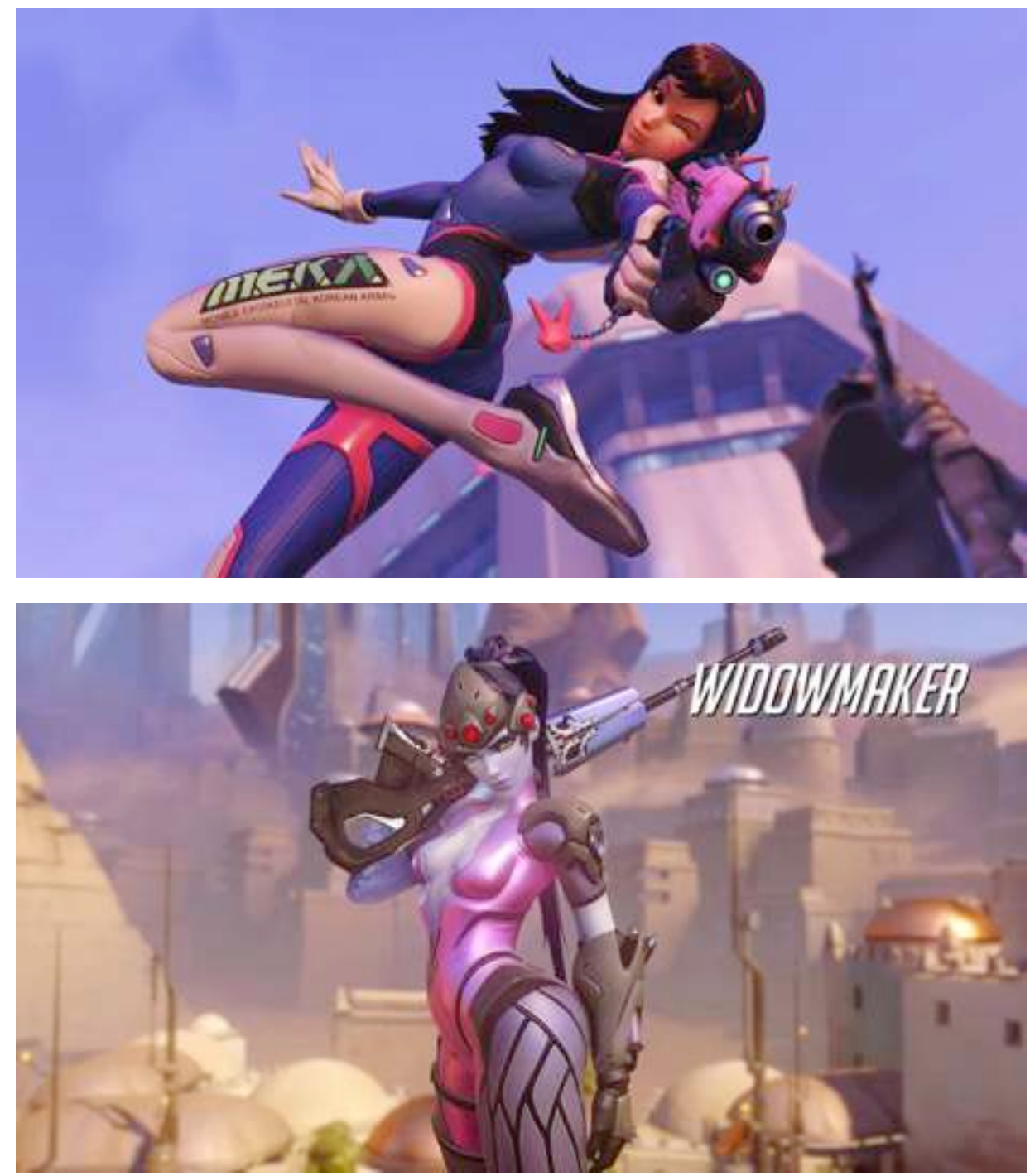

Imagens 50 e 51: Imagens de apresentação de D.Va, fora de seu mecha, e de Widowmaker.

Para além das representações do feminino, Overwatch ainda apresenta algumas questões interessantes no que diz respeito à variedade linguística. O jogo é, sob determinados pontos de vista, bastante progressista por apresentar variedade racial e étnica, assim como o é ao compor seu conjunto de personagens com uma variedade maior de gênero dentro de cada papel muito embora o de Suporte ainda apresente uma maioria feminina - ou melhor, as personagens femininas são as que pendem para o lado menos agressivo do espectro. No entanto, ainda há elementos curiosos pertinentes à dublagem e localização do jogo nos diversos idiomas.

Como é comum nos jogos digitais da atualidade, as personagens falam frases de efeito e comandos diversos à medida que o jogador executa determinadas ações ou simplesmente caminha pelo cenário; um tiro certeiro, a ativação de uma habilidade com efeitos especiais ou o uso de um comando de agrupamento são seguidos de uma fala 
que busca representar a personagem que o jogador está utilizando. Na versão "original” de Overwatch, todas as falas são, naturalmente, em inglês e como uma espécie de “toque especial" as personagens não-anglófonas apresentam algum tipo de marca linguística para identificar sua origem: Widowmaker, a atiradora de elite francesa, fala com sotaque "carregado", enquanto Lúcio, o DJ brasileiro, usa um dialeto comumente associado a negros periféricos; outros - como Mei, Ana, Sombra e Genji - não apresentam sotaque, mas utilizam frases em seus idiomas de origem aleatoriamente ou quando sua habilidade suprema é utilizada.

Essa característica é bastante interessante do ponto de vista da variedade linguística, uma vez que a Overwatch, como organização internacional, reúne pessoas de diversos lugares diferentes, as quais precisam comunicar-se de alguma maneira; 0 idioma do jogo, que varia de acordo com a versão utilizada pelo jogador, torna-se o padrão de comunicação ao qual as personagens se adequam, mantendo suas marcas de origem. Há, no entanto, um fator bastante curioso na versão brasileira de Overwatch: sendo dublado em português, o esperado para manutenção de coerência seria que todas as personagens que não têm esse idioma como primário apresentassem marcas; no entanto, apenas aquelas já marcadas na versão em inglês o fazem - todas as personagens anglófonas falam português sem qualquer tipo de sotaque ou frase característica. Sendo assim, enquanto Mei utiliza uma frase de efeito em chinês ao ativar sua habilidade suprema e Reinhart tem sotaque alemão "carregado", Tracer (britânica) e McCree (estadounidense) falam português naturalmente.

O inglês tona-se, portanto, uma espécie de padrão a que as outras versões se submetem hierarquicamente e é transferido com naturalidade, sem qualquer marca de estrangeirismo. Esse esforço em caracterizar determinadas personagens como as "de fora" nos é particularmente interessante: Widowmaker é francesa, Mei é chinesa, enquanto Tracer simplesmente é.

A existência condicional pode parecer, à primeira vista, apenas um detalhe de dublagem, mas é análoga ao tipo de interação linguística entre jogadores: a língua inglesa é considerada o padrão comunicativo, uma vez que os jogos são deles e os servidores são localizados no país deles. É bastante comum haver racismo declarado em fóruns, exigindo que se possa barrar não-falantes de inglês dos jogos em equipe. ${ }^{69}$ É

\footnotetext{
${ }^{69}$ Verificar https://us.battle.net/forums/en/overwatch/topic/20753098055 e https://us.battle.net/forums/en/overwatch/topic/20759262791?page=1 (Acesso em Julho de 2019)
} 
essa relação entre hierarquia linguística e não-pertencimento que ecoa a bestialidade destacada em Final Fantasy IX e Final Fantasy X: há subalternidade e desumanização, uma vez que quem não faz parte desse grupo não é bem-vindo. O critério de aceitação total no clube de jogadores de Overwatch é, portanto, bastante seleto; para ser um membro, é preciso ser homem e falar inglês - de preferência sem falhas.

\section{League of Legends}

League of Legends (Riot Games, 2009-presente) é um outro jogo do gênero MOBA que é bastante popular nos dias atuais, contando com milhares de jogadores ao redor do mundo. Embora não seja um jogo de tiro, seu estilo é bastante similar ao de Overwatch: o jogador escolhe antes de cada partida uma das personagens disponíveis, as quais são classificadas de acordo com suas funções; há personagens híbridas, mas, diferentemente de Overwatch, o jogador tem certa liberdade para construir sua personagem - algumas delas podem ser mais ofensivas ou defensivas a depender dos equipamentos comprados, muito embora as habilidades sejam sempre as mesmas em qualquer ocasião.

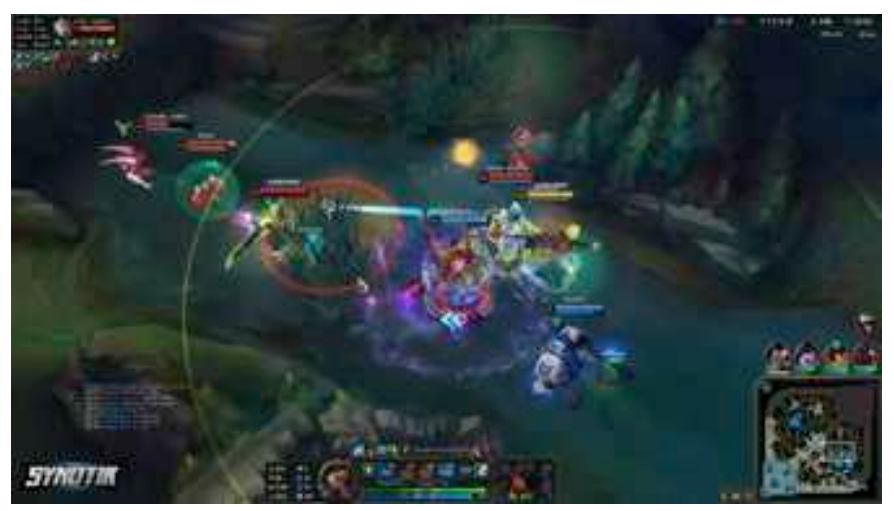

Imagem 52: Trecho de partida de League of Legends ${ }^{70}$

Não há necessidade aqui de repetir a mesma análise que vem sendo feita ao longo desta segunda parte da tese; League of Legends apresenta o mesmo tipo de construção

A menção ao inglês "quebrado" de coreanos no segundo link é particularmente interessante no contexto da discussão desta tese.

${ }^{70} \mathrm{https}: / /$ www.youtube.com/watch?v=-ZwbqqKByKE (Acesso em junho de 2019) 
estereotípica do feminino e há uma relação clara entre isso e mecânicas de jogo - o papel de Suporte é dominado por personagens femininas, muito mais frágeis que as masculinas; Guerreiros são majoritariamente masculinos, e as personagens femininas do grupo têm algum tipo de "truque", como braços mecânicos ou coisas do tipo; quando Causadoras de Dano, fazem uso de armas de longa distância ou de magias, e devem se manter na retaguarda. Não há, portanto, variação em relação ao que se percebe nos jogos de RPG offline ou em Overwatch.
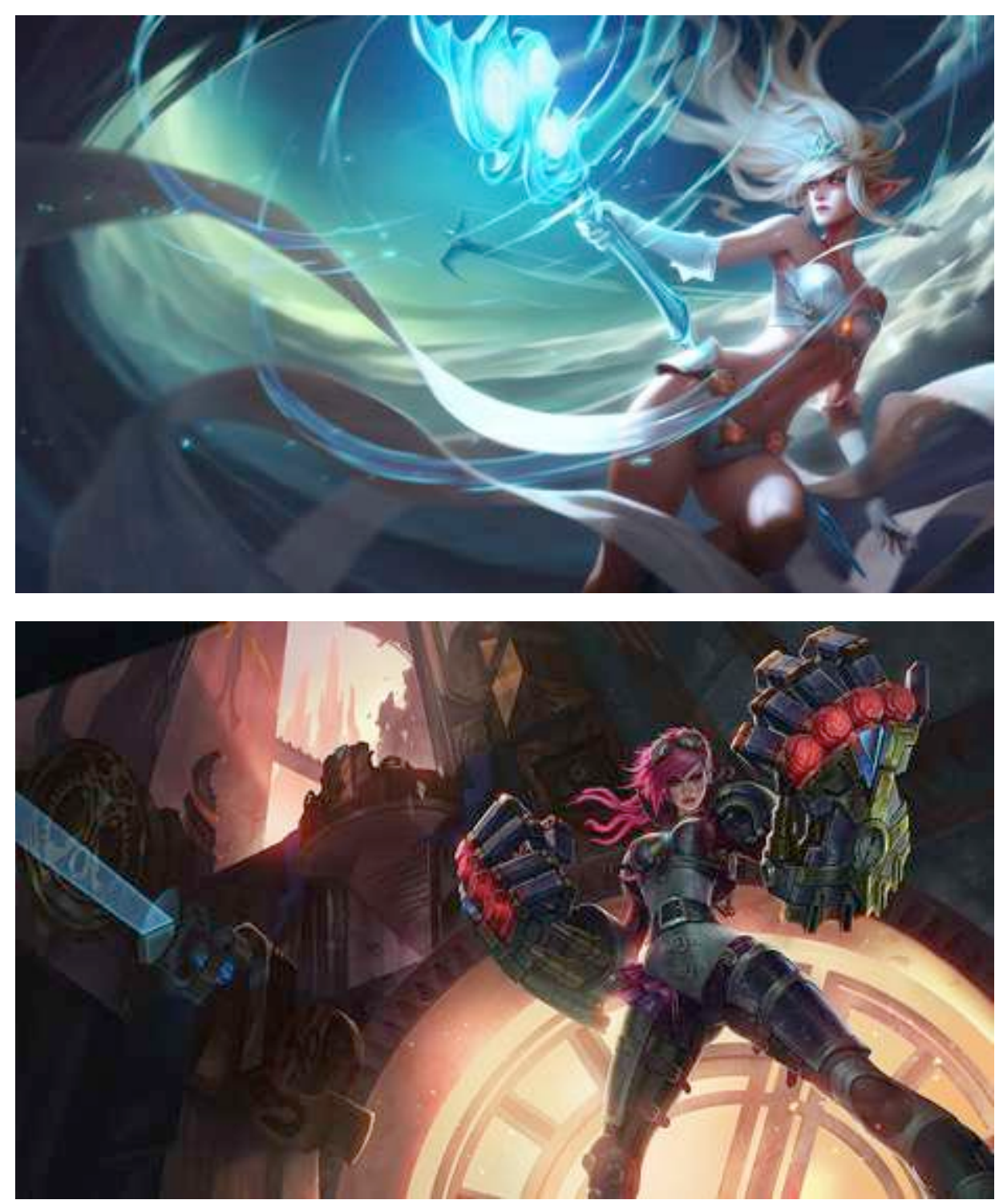


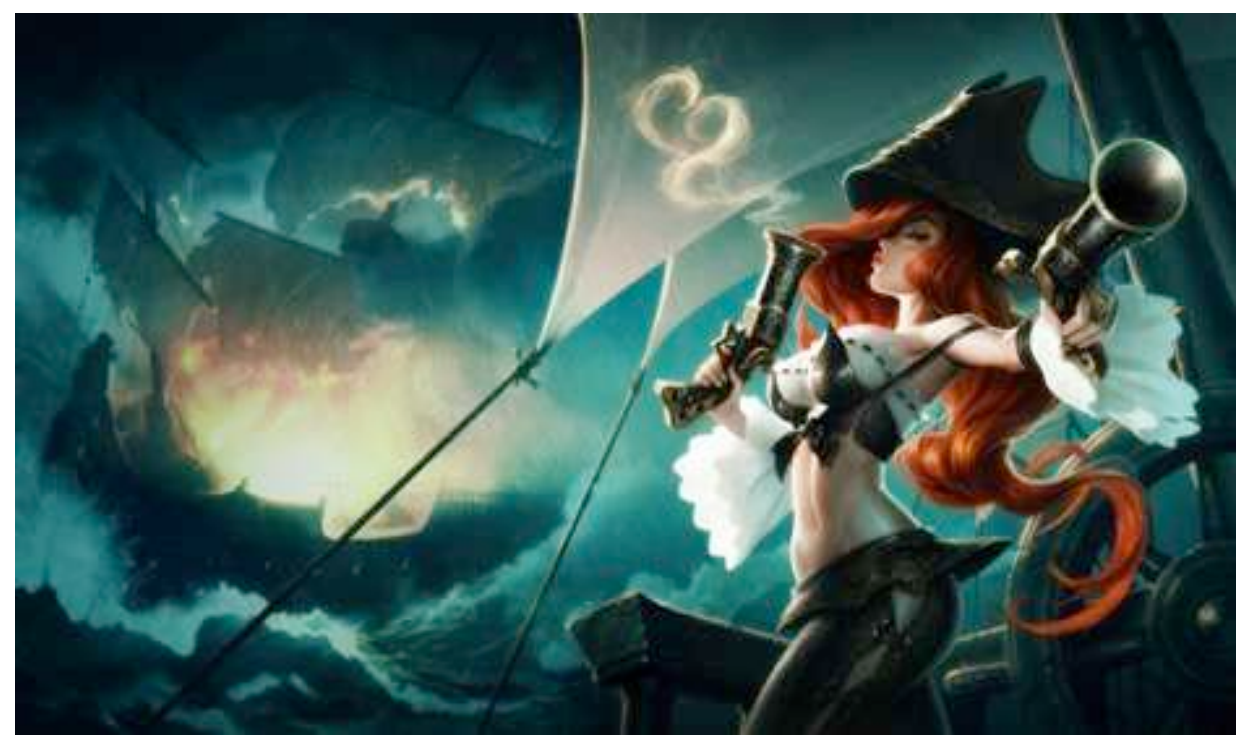

Imagens 53 a 55: As personagens Janna (Suporte), Vi (Guerreira) e Miss Fortune (Atiradora) (Site oficial de League of Legends)

O que nos interessa em particular ao trazer League of Legends como exemplo são os diversos casos de assédio denunciados por funcionárias e ex-funcionárias da empresa Riot Games. Um artigo publicado no site jornalístico Kotaku em agosto de $2018^{71}$, baseado em relatos de diversos funcionários e funcionárias, denuncia a cultura machista que domina a empresa: assédio moral, fotos pornográficas enviadas sem contexto, ostracismo de funcionárias e métodos de entrevista diferenciados - mulheres precisam provar que são gamers "de verdade" por meio de verificações de fatos, perguntas triviais sobre jogos que, segundo os entrevistadores, elas alegam jogar; segundo funcionários, homens não precisavam passar pelo mesmo tipo de verificação, uma vez que são o grupo foco para contratação, por serem de fato gamers.

A empresa negou as acusações e em março de 2019, após meses de repercussão da investigação do site Kotaku, contratou uma especialista em diversidade para resolver a situação de disparidade em contratação e dissipar o ambiente tóxico da empresa; ${ }^{72}$ no entanto, em maio de 2019, mais de 150 funcionários da empresa fizeram uma passeata para protestar contra a cultura de abusos da empresa, que forçava funcionários a fazer acordos judiciais para resolver os processos por assédio sem levá-los a tribunal. ${ }^{73}$ Há,

\footnotetext{
${ }^{71} \mathrm{https} / / /$ kotaku.com/inside-the-culture-of-sexism-at-riot-games-1828165483 (Acesso em Julho de 2019)

72 https://www.theverge.com/2019/3/1/18246622/riot-games-chief-diversity-officer-hire-sexism-allegationstoxic-culture (Acesso em Julho de 2019)

${ }^{73}$ https://www.theguardian.com/games/2019/may/07/riot-games-employees-walk-out-over-workplaceharassment-lawsuits (Acesso em Julho de 2019)
} 
portanto, confirmação da veracidade das questões apresentadas pelo site Kotaku, o qual ecoa o tipo de comportamento apresentado pelos membros da GamerGate, já citada nesta tese.

O que nos interessa particularmente é a conexão entre a cultura tóxica da empresa e a dos jogadores. League of Legends é reconhecido como o jogo online mais problemático disponível no mercado ${ }^{74} \mathrm{e}$, dentre as questões, a misoginia é uma das mais proeminentes; em uma partida profissional de League of Legends em um campeonato russo, o time feminino Vaevictis sofreu com uma atitude antidesportiva por parte do oponente, a equipe RoX, que decidiu banir apenas personagens de Suporte da escolha de campeões antes da partida ${ }^{75}$. O banimento de personagens, uma das estratégias do jogo, tem como objetivo garantir que equipes possam impedir os adversários de escolherem determinadas personagens que possam, de alguma maneira, constituir uma ameaça muito grande para a tática adotada durante a partida; a título de exemplo, se a personagem Draven for considerada perigosa e tiver potencial para explorar uma fraqueza do time $A$, este pode banir Draven da escolha, impedindo que a equipe $B$ o selecione para o jogo. No caso apresentado, a equipe RoX deixou de lado o uso estratégico da possibilidade de banimento para provocar o time feminino, aludindo ao estereótipo machista de que "mulher só presta para jogar de Suporte", extremamente difundido na comunidade de League of Legends.

A relação é clara: historicamente, personagens femininas desempenhavam majoritariamente papeis de suporte em jogos digitais, como demonstramos nas análises de Final Fantasy IX e Final Fantasy X; essa associação temático-figurativa com mecânicas

\footnotetext{
${ }^{74}$ Verificar a lista, que também contém Overwatch e World of Warcraft, o qual é também produzido pela empresa Blizzard.
}

https://www.ranker.com/list/video-games-with-toxic-communities/melissa-brinks (Acesso em Julho de 2019)

https://kotaku.com/how-league-of-legends-enables-toxicity-1693572469 (Acesso em Julho de 2019)

Alguns usuários associam a cultura tóxica dos jogos diretamente às mecânicas de jogo em https://www.quora.com/Why-is-the-League-of-Legends-community-so-toxic (Acesso em Julho de 2019) ${ }_{75} \quad$ https://vs.com.br/artigo/lol-jogadores-da-rox-banem-apenas-suportes-contra-time-feminino-vaevicts (Acesso em Julho de 2019)

https://www.voxel.com.br/noticias/time-feminino-lol-sofre-atitude-antidesportivaestreia_841963.htm (Acesso em Julho de 2019)

Especial atenção para a seção de comentários em que o ataque preconceituoso a elas é justificado por vários usuários. 
de jogo constitui-se como um lugar-comum no discurso ludo-digital, passando a ser largamente utilizada como um dos blocos de construção de jogos - um processo bastante semelhante ao da imitação aristotélica ou horaciana; a cultura misógina predominante em nossa sociedade, em especial nos campos de tecnologia, alimenta o estereótipo e o leva a extremos dentro da comunidade de jogadores, constituindo-o como parte integrante da cultura - batizada como cultura gamer; empresas de jogos, como a Riot Games, valorizam em suas contratações membros desse grupo social, dando-lhes liberdade criativa para produzir jogos; os jogos da "nova geração" apresentam viés ideológico alinhado com o grupo social dominante, excluindo quem não consegue se enquadrar - e a partir disso, o processo se repete.

Grupos minoritários - sub-representados nos jogos digitais e, quando representados, o são a partir do ponto de vista do grupo dominante (opressor) - não são classificados como gamers "de verdade", e portanto não fazem parte do grupo a quem os jogos se dirigem como produto (público-alvo) e também não estão aptos a contratação de acordo com os critérios de seleção. Historicamente, minorias nãobrancas e não masculinas foram excluídas do avanço tecnológico por diversas questões, como as financeiras - como é o caso da população dos países do dito terceiro mundo e culturais - a ideia de que video-games não eram apropriados para garotas; no cenário atual, excluídas do processo produtivo, essas minorias devem conformar-se com 0 consumo silencioso de jogos e experienciar os espaços digitais de acordo com o que o grupo dominante considera como verdadeiro - ou seja, mulheres, negros, latinos e demais grupos historicamente excluídos devem "engolir" o modo como são representados, deixar de lado suas opiniões, queixas e até mesmo seus idiomas, e adotar modos de vivenciar o espaço ludo-digital que lhes são pré-estabelecidos por uma cultura que não tem interesse em acomodar novas formas de semiotizar desse espaço agora compartilhado. A não-conformidade é, como visto no caso da GamerGate, punida com sanções que extrapolam o limite dos jogos e têm consequências muito reais. 


\section{Considerações Finais}

Como dito nas Considerações Iniciais, está foi uma Tese-Ensaio. Seria uma contradição dizer que há uma resposta clara e precisa para os problemas aqui apresentados, uma vez que a definição de jogo que adotamos ao longo destas páginas é centrada num conceito de espaço que não se pretende absoluto. Este se define a partir do corpo histórico e das vivências únicas de cada indivíduo que o habita e por ele se define.

O que buscamos foi demonstrar uma insuficiência reconhecida nas diversas epistemologias vigentes em ludologia no que diz respeito à análise de um problema que se torna cada vez mais explícito no mundo dos jogos digitais: o fato de que a variedade observada na comunidade de jogadores gera conflitos com consequências sérias que extrapolam os limites do que se considera jogo - estruturalmente falando - e demonstra que a apropriação livre do lúdico - como definida pela teoria do jogar - não funciona de modo universal. Essa insuficiência deriva justamente do caráter universalizante dessas teorizações, cujas bases datam de séculos antes e de conceitos de Universalidade hoje em dia questionáveis.

Não se trata, evidentemente, de uma tentativa de tabula rasa, uma vez que as contribuições de tais teorizações são palpáveis e extremamente importantes. $O$ que se pretende é demonstrar que é preciso mais para dar conta de um problema que tem origem justamente nas concepções de Universalidade que norteiam o referencial teórico mais proeminente na área. Para superar esses desafios, conceitos que problematizem essa base são necessários.

As consequências da mobilização dessas teorias outras são a impossibilidade de trazer uma definição rígida e fixa para o objeto. É preciso que mais corpos e vozes se aliem para que possamos começar a compreender a dimensão do objeto em sua complexidade; é preciso construir coletivamente uma definição - ou várias - para dar conta do que é, para cada um, o jogar. 


\section{Referências bibliográficas}

AHMED, S. Queer Phenomenology: Orientations, Objects, Others. Durham: Duke University Press, 2006.

ALCOFF, L. Visible Identities: Race, Gender and Self. Nova lorque: Oxford University Press, 2006.

ALTON, C. The Play is the Thing: Virtual Embodiment and the Player/Avatar Relationship in Digital Games. Trabalho apresentado na conferência anual da Canadian Game Studies Association, Calgary, 2016.

BERENDT, B.; BUDAC, A.; BUDAC, R.; CHEE, F.; GOUGLAS, S.; KUZNETSOVA, E.; PALMER, Z.; PELLETIER-GAGNON, J.; ROCKWELL, G.; SUOMELA, T.; WILSON, M. G@merG@te Origins. Painel apresentado na conferência anual da Canadian Game Studies Association, Calgary, 2016.

BOGOST, I. Unit Operations: An Approach to Videogame Criticism. Cambridge: MIT Press, 2006. E-Book sem paginação.

. Persuasive Games: The Expressive Power of Videogames. Cambridge: MIT Press, 2007. E-Book sem paginação.

How to do Things with Videogames. Minneapolis: University of Minnesota Press, 2011. E-Book sem paginação.

CAILLOIS, R. Les jeux et les hommes: le masque et le vertige. Paris: Gallimard, 2000. 
CASTRO-GÓMEZ, S. "Decolonizar la universidad. La hybris del punto cero y el diálogo de saberes”. In: GROSFOGUEL, R.; CASTRO-GÓMEZ, S. (org.) El giro decolonial: reflexiones para una diversidad epistémica más allá del capitalismo global. Bogotá: Siglo del Hombre Editores; Universidad Central, Instituto de Estudios Sociales Contemporáneos y Pontificia Universidad Javeriana, Instituto Pensar, 2007, pp. 79-92

COUCHOT, E. "Da representação à simulação: evolução das técnicas e das artes da figuração". In: Imagem máquina: a era das tecnologias do virtual. Org. André Parente. Rio de Janeiro, Editora 34, 1993. p. 37-48.

CRAWFORD, C. The Art of Computer Game Design. Vancouver: Washington State University, 1997. Disponível em: http://wwwrohan.sdsu.edu/ stewart/cs583/ACGD_ArtComputerGameDesign_ChrisCrawford_1982.p df (Acesso em Julho de 2019)

DESCARTES, R. Discurso do Método. Tradução de Paulo Neves. Porto Alegre: L\&PM, 2011.

DETERDING, S. A Manifesto, With Footnotes. A Review of Miguel Sicart's "Play Matters". Game Studies, volume 15, edição 1, julho. 2015. Disponível em: http://gamestudies.org/1501/articles/deterding_s (Acesso em 23 de abril de 2017).

\section{DOREY, S. Starting Zones: Studying a Potential Intersection of Cultural} Geography and Game Studies. Trabalho apresentado na conferência anual da Canadian Game Studies Association, Calgary, 2016.

FLUSSER, V. Filosofia da caixa preta: Ensaios para uma futura história da fotografia. São Paulo: Annablume, 2011.

FONTANILLE, J. Formes de Vie. Liège: Presses Universitaires de Liège, 2015. 
GEERTZ, C. "The impact of the concept of culture on the concept of man". In: The interpretation of cultures. Nova lorque: Basic Books, 1973, pp. 33-54.

GREIMAS, A. J. Du Sens: Essais Sémiotiques. Paris: Éditions du Seuil, 1970. . Sobre o Sentido II: Estudos Semióticos. São Paulo: Edusp, 2014.

GREIMAS, A. J.; COURTÉS, J. Sémiotique: Dictionnaire raisonné de la théorie du language, tome 2. Paris: Hachette, 1986.

. Dicionário de Semiótica. São Paulo: Contexto, 2012.

GREIMAS, A. J.; FONTANILLE, J. Sémiotique des passions: Des états de choses aux états d'âme. Paris: Éditions du Seuil, 1991.

GROSFOGUEL, R. "Descolonizando los universalismos occidentales: el pluriversalismo transmoderno decolonial desde Aimé Césaire hasta los zapatistas". In: GROSFOGUEL, R.; CASTRO-GÓMEZ, S. (org.) El giro decolonial: reflexiones para una diversidad epistémica más allá del capitalismo global. Bogotá: Siglo del Hombre Editores; Universidad Central, Instituto de Estudios Sociales Contemporáneos y Pontificia Universidad Javeriana, Instituto Pensar, 2007, pp. 63-77

GROSFOGUEL, R.; CASTRO-GÓMEZ, S. (org.) El giro decolonial: reflexiones para una diversidad epistémica más allá del capitalismo global. Bogotá: Siglo del Hombre Editores; Universidad Central, Instituto de Estudios Sociales Contemporáneos y Pontificia Universidad Javeriana, Instituto Pensar, 2007.

GROUPE $\mu$. Principia Semiotica: aux sources du sens. Bruxelas: Les Impressions Nouvelles, 2015. 
HOUAISS, A. Dicionário Houaiss da Língua Portuguesa. Rio de Janeiro: Objetiva, 2009

HUIZINGA, J. Homo Ludens: a study of the play-element in culture. Londres: Routledge e Kegan Paul, 1949.

JUUL, J. Half-Real: Video Games between Real Rules and Fictional Worlds. Cambridge: MIT Press, 2005. E-Book sem paginação.

KANT, I. Crítica da Razão Pura. Coleção Os Pensadores. Tradução de Valerio Rohden e Udo Baldur Moosburger. São Paulo: Nova Cultural, 1999.

LAMEIRA, A.; GAWRYSZEWSKI, L.; PEREIRA JR., A. Neurônios Espelho. Psicologia USP. Volume 17, edição 4. Dezembro, 2006, pp. 123-133.

LIVINGSTONE, P.; HOGSON, J. Playing in Drag: A Study on Gender Choice In Virtual and Non-Virtual Gaming. Trabalho apresentado na conferência anual da Canadian Game Studies Association, Calgary, 2016.

MENDES, M. Poesia completa e prosa. Rio de Janeiro: Nova Aguilar, 1995.

MURRAY, J. Hamlet in the Holodeck: The Future of Narrative in Cyberspace. Cambridge: MIT Press, 1997.

PEIRCE, C. S. Semiótica. São Paulo: Perspectiva, 1977.

SALEN, K.; ZIMMERMAN, E. Rules of Play: Game Design Fundamentals. Cambridge: MIT Press, 2004. E-Book sem paginação. . The Game Design Reader: A Rules of Play Anthology. Cambridge: MIT Press, 2006. 
SANTAELLA, L. Matrizes da linguagem e pensamento: sonora, visual, verbal. São Paulo: lluminuras, 2009.

SICART, M. Against Procedurality. Game Studies. Volume 11, edição 3. Dezembro, 2011. Sem paginação. Disponível em: http://gamestudies.org/1103/articles/sicart_ap (Acesso em Julho de 2019) Play Matters. Cambridge: MIT Press, 2014.

WALDIE, R. Identity Tourism in Virtual Space: The Virtual Identity Play DressUp Box. Trabalho apresentado na conferência anual da Canadian Game Studies Association, Calgary, 2016.

ZILBERBERG, C.; FONTANILLE, J. Tensão e Significação. São Paulo: Discurso Editorial e Humanitas, 2001. 